UNIVERSIDADE DE SÃO PAULO

ESCOLA DE ENGENHARIA DE SÃO CARLOS

DEPARTAMENTO DE ENGENHARIA DE ESTRUTURAS

LABORATÓRIO DE MADEIRAS E DE ESTRUTURAS DE MADEIRA

\title{
AVALIAÇÃO DA RESISTÊNCIA DE LIGAÇÕES \\ COM PARAFUSOS AUTO-ATARRAXANTES DO \\ TIPO TORX SOLICITADOS POR TRAÇÃO \\ AXIAL, EM PEÇAS DE MADEIRA
}

\section{Ricardo Rizzo Correia}

\author{
Dissertação apresentada à Escola de Engenharia \\ de São Carlos da Universidade de São Paulo, \\ como parte dos requisitos para a obtenção do \\ título de Mestre em Engenharia de Estruturas. \\ ORIENTADOR: Prof. Dr. Antônio Alves Dias \\ ÁREA DE CONCENTRAÇÃO: Engenharia de Estruturas
}

São Carlos

2002 
Aos meus pais. 


\section{AGRADECIMENTOS}

Agradecimentos à minha família que me incentivou para a concretização deste trabalho.

Em especial, ao Professor Dr. Antonio Alves Dias pela excelente orientação e amizade.

Ao professor Ernst Gehri ao colaborar com a proposta deste trabalho.

Ao CNPQ - Conselho Nacional de Desenvolvimento Científico e Tecnológico, pela concessão da bolsa de estudos para o desenvolvimento desta pesquisa.

A todos os colegas, professores e funcionários do Laboratório de Madeiras e Estruturas de Madeira e do Departamento de Engenharia de Estruturas, que direta ou indiretamente, participaram na elaboração deste trabalho. 
LISTA DE FIGURAS ………………………………………………..... vii

LISTA DE TABELAS ……………………………………………….... ix

LISTA DE ABREVIATURAS E SIGLAS ........................................ xiii

LISTA DE SÍMBOLOS ……………………………………………….... xiv

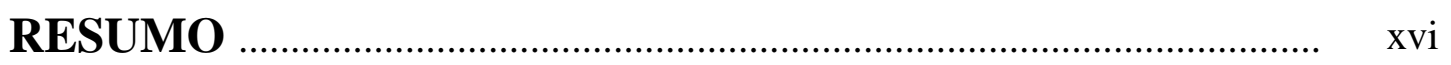

ABSTRACT ………………………………………………………….. xvii

1. INTRODUÇÃ

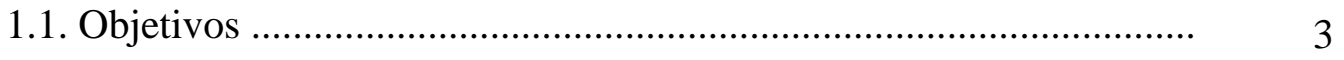

2. REVISÃO BIBLIOGRÁFICA …………………………………...... 4

2.1. Introdução ………………………………………………………...

2.1.2. Parafuso de Fenda para Madeira (Wood Screw) ............................. 4

2.1.2. Parafuso Auto-atarraxante (Lag Screw) ........................................ 5

2.2. Exemplos de Aplicação dos Parafusos Torx Auto-atarraxantes ......... 6

2.3. Aspectos que Influenciam a Resistência da Ligação ............................ 10

2.4. Normalização e Critérios de Dimensionamento ................................ 20

2.4.1. Deustches Institut für Nurming (1998) ..................................... 20

2.4.2. American National Standard (1991) ................................................ 21

2.4.3. Comité Européen de Normalisation (1993) ................................... 24

2.4.4. Canadian Standard Association (1993) .......................................... 25

2.4.5. Standards Association of Australia (1994) .................................... 27

2.4.6. Associação Brasileira de Norma técnicas (1997) .......................... 30

2.4.7. Forest Products Laboratory (1999) ……………………………... 31

2.4.7.1. Resistência à tração - Parafuso de Fenda para Madeira .......... $\quad 31$

2.4.7.1. Resistência à tração - Parafusos Auto-atarraxantes.................. 32

2.5. Conclusões da Revisão Bibliográfica ......................................... 34 
3. MATERIAIS E MÉTODOS ……………………………………..... 36

3.1. Materiais Utilizados ....................................................................... 36

3.2. Procedimentos Utilizados nos Ensaios das Ligações............................ 37

3.2.1. Ensaios Realizados .................................................................. 37

3.2.1.1. Ensaios Preliminares ............................................................. 37

3.2.1.2. Ensaios Principais ................................................................. 38

3.2.1.3. Ensaios Secundários ............................................................. 38

3.2.1.4. Programa Experimental Realizado …………………………... 39

3.2.2. Extração dos Corpos-de-prova ......................................................... 40

3.2.3. Base de Fixação dos Parafusos ...................................................... 42

3.2.4. Dimensões e Montagem dos Corpos-de-prova …………………... 42

3.2.5. Arranjo dos Ensaios .....................................................................

3.2.6. Forma de Aplicação do Carregamento .............................................

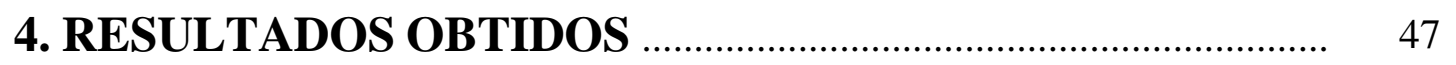

4.1. Ensaios Preliminares …………………………………………….... 48

4.2. Ensaios Principais …………………………………………….... 50

4.2.1. Pinus Taeda …………………………………….................... 51

4.2.2. Eucalipto Grandis ........................................................................ 53

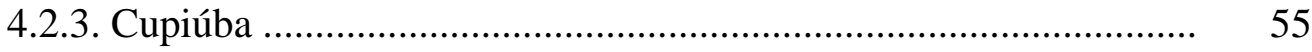

4.3. Ensaios Secundários ………………………………………….... 57

4.3.1. Pinus Taeda ……………………………………..................... 57

4.3.2. Eucalipto Grandis ......................................................................... 60

5. ANÁLISE DOS RESULTADOS ...................................................... 63

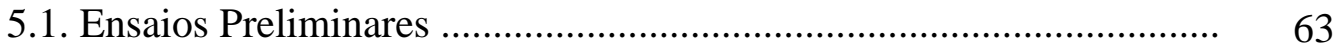

5.2. Ensaios Principais ……………………………………………..... 65

5.3. Ensaios Secundários ………………………………………………..... 69

5.3.1. Avaliação da Influência da Massa Específica ................................. 69

5.3.2. Avaliação da Influência do Teor de Umidade ................................ 73 
5.3.3. Avaliação da Influência do Espaçamento entre Parafusos

5.4. Resumos dos Resultados Principais e Secundários ......................... 77

5.5. Sugestão para o Critério de Dimensionamento .................................... 78

5.6. Comparação entre os Critérios de Dimensionamento das Normas Consultadas e o Critério sugerido 81

5.6.1. Critérios Baseados no Método das Tensões Admissíveis 81

5.6.2. Critérios Baseados no Método dos Estados Limites 82

6. CONCLUSÃO 86 


\section{LISTA DE FIGURAS}

Figura 1.1 - $\quad$ Detalhe da ligação de um nó típico de treliça em madeira ................... 2

Figura 1.2 - Detalhe da ligação de um nó de apoio de uma treliça ........................... 2

Figura 2.1 - Modelos de parafusos de fenda para madeira. FONTE: FOREST PRODUCTS LABORATORY (1999) ......................... 5

Figura 2.2 - Parafuso sextavado com rosca soberba …......................................... 5

Figura 2.3 - $\quad$ Parafuso torx auto-atarraxante …...................................................... 6

Figura 2.4 - Exemplo de ligação típica utilizando parafusos torx autoatarraxantes. FONTE: MISCHLER (2000) ...................................... 7

Figura 2.5 - $\quad$ Protótipo de treliça. FONTE: MISCHLER (2000) ……........................ 7

Figura 2.6 - Modo de ruptura da ligação. FONTE: MISCHLER (2000) ……......... $\quad 8$

Figura 2.7 - $\quad$ Ligação com parafusos torx auto-atarraxante. FONTE: SFS (2002) .. $\quad 8$

Figura 2.8 - Outras formas de ligação com parafuso torx auto-atarraxante. FONTE: SFS (2002) .

Figura 2.9 - $\quad$ Base de fixação para utilização da parafusadeira. FONTE: SFS (2002)

Figura 2.10 - Exemplo de utilização no canteiro de obras. FONTE: SFS (2002)...... 10

Figura 2.11 - Parafusos após sua fixação nas vigas. FONTE: SFS (2002) …............ 10

Figura 2.12 - Gráfico da resistência à tração utilizando parafusos auto-atarraxantes em diferentes profundidades de penetração. FONTE: NEWLIN e GAHAGAN (1938)

Figura 2.13 - Relação entre a resistência à tração para diferentes diâmetros de parafusos auto-atarraxantes e a densidade da madeira. FONTE: NEWLIN e GAHAGAN (1938)

Figura 2.14 - Relação entre a resistência à tração x densidade. FONTE: NEWLIN e GAHAGAN (1938) .................................................................... 14

Figura 2.15 - Exemplo de ligação. FONTE: FREIRER (1963) …........................... 15

Figura 2.16 - Ligação com parafuso auto-atarraxante. FONTE: VAZ (1987) …....... 16

Figura 2.17 - Método de ensaio para arrancamento direto. FONTE: VAZ (1987) 17 
Figura 2.18 - Gráfico comparativo entre as equações. FONTE: MCLAIN (1997) ‥ 20

Figura 3.1 - Parafuso torx auto-atarraxantes modelo FB-SK-T30.......................... 36

Figura 3.2 - Disposição dos corpos-de-prova para extração..................................... $\quad 41$

Figura 3.3 - Bases de fixação............................................................................... 42

Figura 3.4 - Dimensões dos corpos-de-prova dos ensaios preliminares................... $\quad 42$

Figura 3.5 - Dimensões dos corpos-de-prova com os parafusos dispostos paralelamente às fibras........................................................................ 43

Figura 3.6 - Dimensões dos corpos-de-prova com os parafusos dispostos perpendicularmente às fibras............................................................... 44

Figura 3.7 - $\quad$ Ensaio para parafusos na direção paralela às fibras............................... $\quad 45$

Figura 3.8 - $\quad$ Ensaio para parafusos na direção perpendicular às fibras...................... $\quad 45$

Figura 4.1 - Representação dos comprimentos de rosca.......................................... 47

Figura 4.2 - Forma de ruptura para parafusos paralelos às fibras - deslizamento do parafuso................................................................................ 50

Figura 4.3 - Forma de ruptura para parafusos perpendicular às fibras..................... $\quad 50$

Figura 5.1 - Análise dos resíduos - Variação de resistência ..................................... 64

Figura 5.2 - $\quad$ Análise dos resíduos - Grupo de parafusos paralelos às fibras............. $\quad 66$

Figura 5.3 - $\quad$ Análise dos resíduos - Grupo de parafusos paralelos às fibras Corrigido.

Figura 5.4 - Análise dos resíduos - Variação de massa específica - Pinus Taeda....

Figura 5.5 - Análise dos resíduos - Variação de massa específica - Eucalipto Grandis.

Figura 5.6 - Análise dos resíduos corrigidos - Variação de massa específica Eucalipto Grandis.

Figura 5.7 - $\quad$ Análise dos resíduos - Variação do teor de umidade - Eucalipto Grandis.

Figura 5.8 - $\quad$ Análise dos resíduos - Variação do espaçamento - Pinus Taeda.......... $\quad 75$

Figura 5.9 - Análise dos resíduos - Variação do espaçamento - Pinus Taeda Corrigido 


\section{LISTA DE TABELAS}

Tabela 2.1 - Resistência nominal à tração utilizando parafusos auto-atarraxantes em $(\mathrm{N} / \mathrm{mm})$

Tabela 2.2 - Distância requerida da borda lateral .................................................... 23

Tabela 2.3 - Distância requerida do fim da peça ..................................................... 23

Tabela 2.4 - Distância entre fileiras de parafusos ................................................... 23

Tabela 2.5 - Espaçamento entre parafusos entre fileiras …….................................. 24

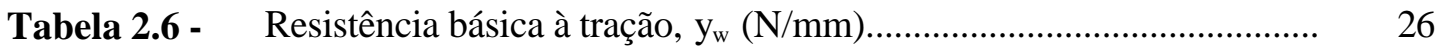

Tabela 2.7 - Resistência característica à tração, $(\mathrm{N} / \mathrm{mm})$ - Madeira com teor de umidade acima do ponto de saturação................................................ 29

Tabela 2.8 - Resistência característica à tração, $(\mathrm{N} / \mathrm{mm})$ - madeira seca ao ar..........

Tabela 3.1 - Ensaios realizados em corpos-de-prova com 1 parafuso (Ensaios preliminares)

Tabela 3.2 - Ensaios realizados em corpos-de-prova com 4 parafusos (Ensaios principais e secundários)

Tabela 3.3 - Ensaios realizados em corpos-de-prova com 8 parafusos (Ensaios principais)

Tabela 3.4 - Ensaios realizados em corpos-de-prova com 16 parafusos (Ensaios principais)

Tabela 4.1 - Resistência e modo de ruptura da ligação em relação ao comprimento de rosca inserida na madeira - Espécie Cupiúba............ 48

Tabela 4.2 - $\quad$ Propriedades da madeira - Ensaios preliminares................................... 48

Tabela 4.3 - Determinação da variação de resistência da ligação - Pré-furação 6,0 $\mathrm{mm}$

Tabela 4.4 - Determinação da variação de resistência da ligação - Pré-furação 5,5 $\mathrm{mm}$

Tabela 4.5 - $\quad$ Ensaios com 4 parafusos paralelos às fibras - Pinus Taeda................... $\quad 51$

Tabela 4.6 - Ensaios com 8 parafusos paralelos às fibras - Pinus Taeda.................. 51

Tabela 4.7 - Ensaios com 16 parafusos paralelos às fibras - Pinus Taeda.................. $\quad 52$

Tabela 4.8 - $\quad$ Ensaios com 4 parafusos perpendiculares às fibras - Pinus Taeda....... 52 
Tabela 4.9 - Ensaios com 8 parafusos perpendiculares às fibras - Pinus Taeda....... $\quad 52$

Tabela 4.10 - Ensaios com 4 parafusos paralelos às fibras - Eucalipto Grandis......

Tabela 4.11 - Ensaios com 8 parafusos paralelos às fibras fibras - Eucalipto Grandis.

Tabela 4.12 - Ensaios com 16 parafusos paralelos às fibras fibras - Eucalipto Grandis

Tabela 4.13 - Ensaios com 4 parafusos perpendiculares às fibras fibras - Eucalipto Grandis.

Tabela 4.14 - Ensaios com 8 parafusos perpendiculares às fibras fibras - Eucalipto Grandis.

Tabela 4.15 - Ensaios com 4 parafusos paralelos às fibras Cupiúba...

Tabela 4.16 - Ensaios com 8 parafusos paralelos às fibras fibras Cupiúba......

Tabela 4.17 - Ensaios com 16 parafusos paralelos às fibras fibras Cupiúba.

Tabela 4.18 - Ensaios com 4 parafusos perpendiculares às fibras fibras Cupiúba.

Tabela 4.19 - Ensaios com 8 parafusos perpendiculares às fibras fibras Cupiúba.

Tabela 4.20 - Massa específica mínima - 4 parafusos paralelos às fibras - Pinus Taeda

Tabela 4.21 - Massa específica máxima - 4 parafusos paralelos às fibras - Pinus Taeda

Tabela 4.22 - Massa específica mínima - 4 parafusos perpendiculares às fibras Pinus Taeda.

Tabela 4.23 - Massa específica máxima - 4 parafusos perpendiculares às fibras Pinus Taeda

Tabela 4.24 - Espaçamento de $15 \mathrm{~mm}$ entre parafusos - 4 parafusos paralelos às fibras - Pinus Taeda.

Tabela 4.25 - Espaçamento de $30 \mathrm{~mm}$ entre parafusos - 4 parafusos paralelos às fibras - Pinus Taeda.

Tabela 4.26 - Espaçamento de $45 \mathrm{~mm}$ entre parafusos - 4 parafusos paralelos às fibras - Pinus Taeda. 
Tabela 4.27 - Massa específica mínima - 4 parafusos paralelos às fibras - Eucalipto Grandis

Tabela 4.28 - Massa específica máxima - 4 parafusos paralelos às fibras Eucalipto Grandis

Tabela 4.29 - Massa específica mínima - 4 parafusos perpendiculares às fibras Eucalipto Grandis

Tabela 4.30 - Massa específica máxima - 4 parafusos perpendiculares às fibras Eucalipto Grandis

Tabela 4.31 - Umidade: $20 \%$ - 4 parafusos paralelos às fibras - Eucalipto Grandis..

Tabela 4.32 - Ponto de saturação - 4 parafusos paralelos às fibras - Eucalipto Grandis

Tabela 4.33 - Umidade: $20 \%$ - 4 parafusos perpendiculares às fibras - Eucalipto Grandis

Tabela 4.34 - Ponto de saturação - 4 parafusos perpendiculares às fibras Eucalipto Grandis

Tabela 5.1 - $\quad$ Análise da variância para verificação da influência dos fatores........... $\quad 64$

Tabela 5.2 - Média das resistências em função da pré-furação................................. 65

Tabela 5.3 - $\quad$ Análise da variância para grupos de parafusos paralelos às fibras....... $\quad 66$

Tabela 5.4 - Análise da variância para grupos de parafusos paralelos às fibras Corrigido.

Tabela 5.5 - Resistência $(\mathrm{N} / \mathrm{mm})$ para parafusos fixos paralelamente às fibras.......

Tabela 5.6 - Resistência $(\mathrm{N} / \mathrm{mm})$ para parafusos fixos perpendicularmente às fibras.

Tabela 5.7 - $\quad$ Resistência para parafusos fixos paralelamente às fibras - Pinus Taeda.

Tabela 5.8 - Influência da massa específica - Pinus Taeda........................................ $\quad 69$

Tabela 5.9 - Resistência para parafusos fixos paralelamente às fibras - Eucalipto Grandis.

Tabela 5.10 - Influência da massa específica - Eucalipto Grandis............................. 71

Tabela 5.11 - Influência da massa específica - Eucalipto Grandis - Corrigido.......... $\quad 72$

Tabela 5.12 - Resistência média corrigida - Parafusos paralelos às fibras Eucalipto Grandis.. 
Tabela 5.13 - Resistência para parafusos fixos paralelo às fibras - Eucalipto

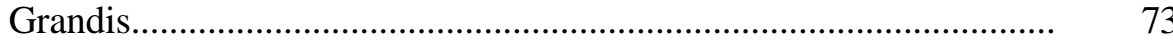

Tabela 5.14 - Influencia do teor de umidade - Eucalipto Grandis................................ 74

Tabela 5.15 - Resistência média em função do espaçamento - parafusos fixos paralelamente às fibras - Pinus Taeda................................................. 75

Tabela 5.16 - Influência da variação dos espaçamentos entre parafusos..................... $\quad 75$

Tabela 5.17 - Influência da variação dos espaçamentos entre parafusos - Corrigido. 76

Tabela 5.18 - Resistência para parafusos fixos paralelo às fibras - Pinus Taeda........ $\quad 77$

Tabela 5.19 - Resistência para parafusos fixos perpendiculares às fibras - Pinus Taeda..................................................................................... 77

Tabela 5.20 - Resistência para parafusos fixos paralelo às fibras - Eucalipto

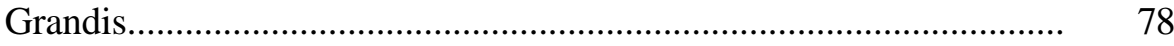

Tabela 5.21 - Resistência para parafusos fixos perpendiculares às fibras - Eucalipto Grandis...................................................................................... 78

Tabela 5.22 - Resistência para parafusos fixos paralelo às fibras - Cupiúba............... 78

Tabela 5.23 - Resistência para parafusos fixos perpendiculares às fibras - Cupiúba. $\quad 78$

Tabela 5.24 - Resumo dos resultados - Comparação entre critérios de

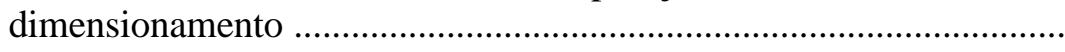




\title{
LISTA DE ABREVIATURAS E SIGLAS
}

\author{
AISI ............ - American Iron and Steel Institute \\ ANSI ........ - American National Standards Institute \\ ASME ...... - American Society of Mechanical Engineers \\ DIN …......... - Deustches Institut Für Nurming \\ CSA ......... - Canadian Standard Association \\ EESC ........... - Escola de Engenharia de São Carlos \\ LaMEM ....... - Laboratório de Madeiras e Estruturas de Madeira \\ NBR ........... - Norma Brasileira Registrada \\ NDS ........... - National Design Specification for Wood Construction \\ SAE ............ - Society of Automotive Engineers \\ SET ............ - Departamento de Engenharia de Estruturas \\ USP ............. - - Universidade de São Paulo
}




\section{LISTA DE SÍMBOLOS}

\section{Letras romanas maiúsculas:}

$\mathrm{E}_{\mathrm{c} 0} \quad$ - Módulo de elasticidade longitudinal obtido no ensaio de compressão paralela às fibras

F $\quad$ - Teste estatístico

$\mathrm{F}_{\mathrm{d}} \quad$ - Força de tração de cálculo

K - Constante

$\mathrm{K}_{\text {grupo }}$ - Coeficiente de redução devido ao efeito de grupo

$\mathrm{L}_{\mathrm{p}, \mathrm{s}} \quad$ - Comprimento do parafuso inserido ao longo de uma peça de madeira

$L_{R} \quad$ - Comprimento de rosca inserida na peça principal de madeira

$\mathrm{L}_{\mathrm{RE}} \quad$ - Comprimento de rosca efetivo na peça principal de madeira

P - Resultado estatístico

R - Resistência à tração para um parafuso

$\mathrm{R}_{90} \quad$ - Resistência máxima de tração na direção perpendicular às fibras

$\mathrm{R}_{\mathrm{ad}} \quad$ - Resistência de tração nominal admissível

$\mathrm{R}_{\mathrm{ad}, 0}$ - Resistência de tração nominal admissível na direção paralela às fibras

$\mathrm{R}_{\mathrm{d}} \quad$ - Resistência de cálculo

$\mathrm{R}_{\mathrm{d}, 0} \quad$ - Resistência de cálculo na direção paralela às fibras

$\mathrm{R}_{\mathrm{d}, 90}$ - Resistência de cálculo na direção perpendicular às fibras

$\mathrm{R}_{\mathrm{k}} \quad$ - Resistência característica

$\mathrm{R}_{\mathrm{L}, \mathrm{d}} \quad$ - Resistência de cálculo por unidade de comprimento de rosca

$\mathrm{R}_{\mathrm{L}, \mathrm{k}} \quad$ - Valor característico da resistência

$\mathrm{R}_{\mathrm{L}, \mathrm{m}} \quad$ - Valor médio da resistência

$\mathrm{R}_{\mathrm{n}} \quad$ - Resistência à tração para n parafusos

$\mathrm{S}_{\mathrm{d}} \quad$ - Solicitação de cálculo

SF - Fator de segurança 


\section{Letras romanas minúsculas:}

d - Diâmetro do parafuso

$\mathrm{d}_{2} \quad$ - Diâmetro da pré-furação

e $\quad$ - Espessura da peça de madeira

f - Capacidade característica de resistência do parafuso

$\mathrm{f}_{3, \mathrm{~d}} \quad$ - Parâmetro de tração de projeto

$\mathrm{f}_{\mathrm{c} 0} \quad$ - Resistência à compressão paralela às fibras

$\mathrm{k}_{13} \quad$ - Coeficiente de minoração

$\mathrm{k}_{\mathrm{D}} \quad$ - Fator de duração de carregamento

$\mathrm{k}_{\text {mod }} \quad$ - Coeficiente de modificação

$\mathrm{k}_{\mathrm{SF}} \quad$ - Fator de condições de utilização

$\mathrm{k}_{\mathrm{T}} \quad$ - Fator de tratamento

$\mathrm{n}_{\mathrm{P}} \quad$ - Número de parafusos

$y_{w} \quad$ - Resistência básica por milímetro de penetração de rosca

\section{Letras gregas:}

$\alpha \quad$ - ângulo

$\phi \quad$ - Coeficiente de minoração de resistência

$\rho \quad$ - Massa específica da madeira

$\rho_{\text {ap }} \quad$ - Massa específica aparente da madeira

$\gamma_{\mathrm{m}}$ - Coeficiente de ponderação das resistências dos materiais

$\gamma_{\mathrm{w}} \quad$ - Coeficiente de minoração da resistência da madeira 


\section{RESUMO}

CORREIA, R. R. (2002). Avaliação da resistência de ligações com parafusos autoatarraxantes do tipo torx solicitados por tração axial, em peças de madeira. São Carlos, 2002, 89p. Dissertação (Mestrado) - Escola de Engenharia de São Carlos, Universidade de São Paulo.

A aplicação da madeira como material estrutural na construção civil é amplamente difundida em coberturas residenciais e comerciais, na construção de residências ou em obras de grande porte como pontes. Freqüentemente ocorre a necessidade de ligações entre peças estruturais. Uma das possibilidades de ligação é a utilização de parafusos auto-atarraxantes solicitados por esforços de tração, diferente da maioria dos casos de ligações, nas quais pinos estão solicitados por forças laterais.

Um tipo particular de parafuso auto-atarraxante é o torx, que possui rosca em toda a sua extensão, possibilitando uma outra forma de arranjo de ligação que facilita a execução das ligações entre as peças estruturais. Este parafuso possui uma grande resistência e traz facilidades à industrialização das estruturas de madeiras.

O objetivo desta pesquisa é determinar, de maneira experimental, a resistência de ligações utilizando parafusos torx auto-atarraxantes submetidos a esforços axiais de tração, em peças de madeira, avaliando a influência de diversos fatores, tais como: direção de fixação dos parafusos em relação às fibras, efeito de grupo, teor de umidade, massa específica da madeira e espaçamentos entre parafusos. Foram utilizadas as espécies: Pinus Taeda (Pinus taeda L.), Eucalipto Grandis (Eucalyptus grandis) e Cupiúba (Goupia glabra).

Palavras Chaves: Ligações, Conexões, Parafusos auto-atarraxantes. 


\section{ABSTRACT}

CORREIA, R. R. (2002). Evaluation of timber strength of connections with torx lag screws requested by axial withdrawal in wooden pieces. São Carlos, 2002, 89p. Dissertação (Mestrado) - Escola de Engenharia de São Carlos, Universidade de São Paulo.

Timber as a structural material civil in construction is widely used in framework, construction of houses or larger construction as bridges. The use of connections among structural members is frequently required. One of the connection possibilities is the use of lag screws in axial withdrawal load, differently from most cases of connections in which they are laterally loaded.

A peculiar type of lag screw is the torx, which possesses thread along its extension, making possible another form of connection arrangement that facilitates the execution of the connections among the structural pieces. This lag screw has a high strength and facilitates the industrialization of timber structures.

The aim of this research is to determine, in an experimental way, the strength of connections using torx lag screws in withdrawal loads, evaluating the influence of several factors, such as direction of the lag screws in relation to grain, group effect, moisture content, density of wood and spacings among screws. The species used were: Pinus Taeda (Pinus taeda L.), Eucalipto Grandis (Eucalyptus grandis) and Cupiúba (Goupia glabra).

Keywords: Connections, Joints, Lag screw. 


\section{INTRODUÇ̃̃o}

A madeira é um material que está disponível em variadas dimensões geralmente inviáveis para utilização imediata, devendo ser cortada em vigas, pranchas e tábuas, permitindo assim a padronização das dimensões, e facilitando o transporte e a comercialização.

A industrialização da madeira como material estrutural ocorreu quando se utilizaram diversos tipos de materiais para fazer as ligações, tais como: pregos, parafusos, parafusos auto-atarraxante, grampos e cavilhas. Cada tipo de ligação requer um projeto adequado, levando em consideração os diversos fatores que o influenciam. Pode-se afirmar que a execução das ligações é um dos fatores que mais influenciam na competitividade das estruturas de madeira.

Uma nova possibilidade de ligação que começa a ser estudada em outros países é a que utiliza um parafuso auto-atarraxante especial, denominado torx, que apresenta rosca em todo o seu comprimento, solicitado por esforços de tração.

Em meados do ano de 2000, o Professor Ernst Gehri, da Escola Eidgenössische Tecnische Hochscule Zürich, da Suíça, em visita ao Laboratório de Madeiras e de Estruturas de Madeira do Departamento de Engenharia de Estruturas, propôs o desenvolvimento de um trabalho com a finalidade de verificar o desempenho desta forma alternativa de ligação, utilizando o parafuso torx auto-atarraxante.

Neste arranjo de ligação, os parafusos estão solicitados por esforços de tração ou compressão, ao contrário da maioria das ligações convencionalmente utilizadas, nas quais os parafusos atuam como pinos, estando solicitados por cisalhamento.

O professor Gehri forneceu parafusos auto-atarraxantes do tipo torx fabricados pela empresa Suíça SFS AG, além de alguns gabaritos utilizados na fixação dos parafusos. Estes possuem como principal característica uma grande variação do comprimento para um mesmo diâmetro. Vale destacar que é possível encontrar fabricantes no Brasil que produzem parafusos semelhantes, sendo necessária à encomenda para algumas dimensões. 
A facilidade de execução das ligações utilizando este tipo de parafuso, com o auxílio de gabaritos e máquinas para atarraxar, possibilitam a industrialização das estruturas de madeira, com a produção seriada de treliças, reduzindo em muito o tempo de montagem e, conseqüentemente, obtendo-se uma maior produtividade na execução de estruturas.

As figuras 1.1 e 1.2 apresentam detalhes de um nó típico de uma treliça e de nós de apoio de uma treliça, respectivamente, como exemplos de aplicação destes parafusos.

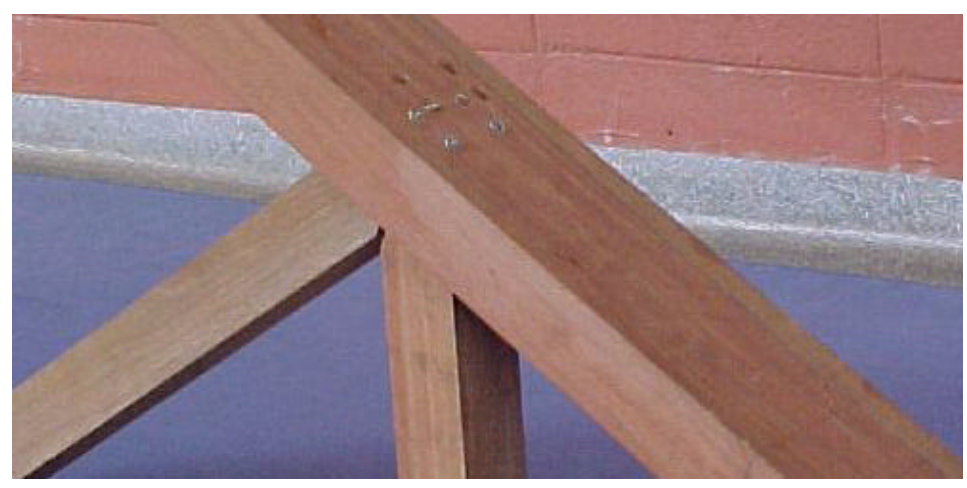

Figura 1.1- Detalhe da ligação de um nó típico de treliça em madeira.

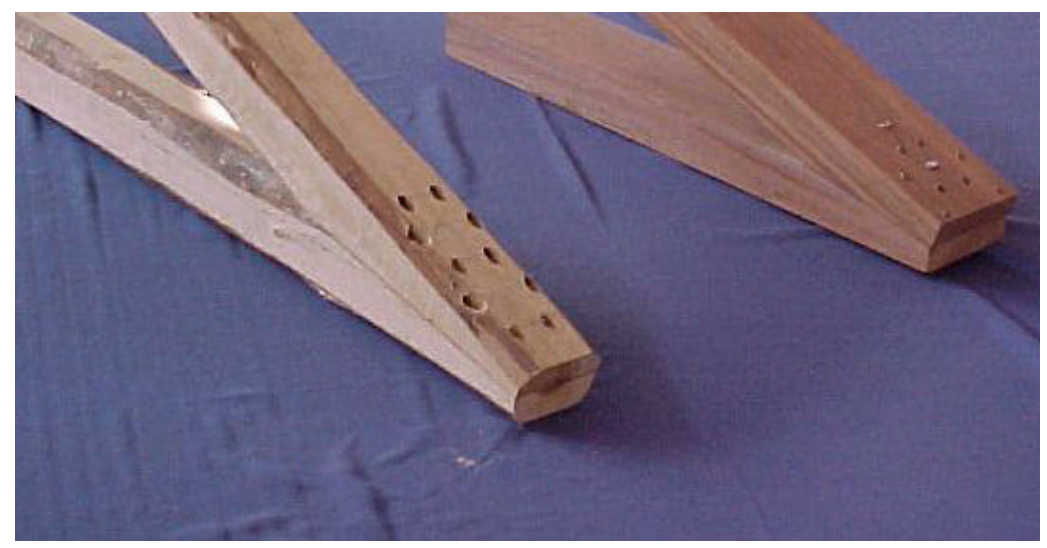

Figura 1.2 - Detalhe da ligação de um nó de apoio de uma treliça.

Dentro deste contexto, este trabalho foi desenvolvido procurando determinar experimentalmente a resistência de ligações com os parafusos torx auto-atarraxantes, avaliando a influência da direção de fixação dos parafusos em relação às fibras, do efeito de grupo (número de parafusos utilizados), das propriedades da madeira (umidade e massa específica), e do espaçamento entre os parafusos. 
Tendo em vista a possibilidade de utilização mais freqüente de madeiras de reflorestamento, a espécie Eucalipto Grandis (Eucalyptus grandis) foi adotada para realização da maioria dos ensaios. Também foram realizados ensaios, em alguns casos para efeito de comparação, com as espécies Pinus Taeda (Pinus taeda L) e Cupiúba (Goupia glabra).

\section{1 - OBJETIVOS}

Este trabalho tem por objetivo determinar a resistência de ligações com parafusos auto-atarraxantes do tipo torx, solicitados por esforços axiais de tração, para três espécies de madeira. É estudada a influência dos seguintes fatores na resistência:

- Ângulo de fixação dos parafusos em relação às fibras da madeira (paralelo ou perpendicular);

- Número de parafusos (efeito de grupo);

- Influência da variação da massa específica da madeira na resistência da ligação;

- Influência do teor de umidade na resistência da ligação;

- Espaçamento entre os parafusos;

Por fim, é proposto um direcionamento com a finalidade de estabelecer um critério de dimensionamento para ligações com este parafuso. 


\section{REVISÃO BIBLIOGRÁFICA}

A seguir são apresentadas as informações obtidas em revisão bibliográfica a respeito dos tipos de parafusos auto-atarraxantes e dos aspectos relacionados ao seu dimensionamento, apresentados em livros, normas internacionais e trabalhos de pesquisa sobre este assunto.

\section{1 - INTRODUÇÃO}

Existem vários modelos de parafusos auto-atarraxantes. A seguir, são apresentados os parafusos auto-atarraxantes usualmente utilizados em estruturas de madeira, enunciando suas características e as diferenças existentes entre os diversos tipos.

\subsection{1 - Parafuso de Fenda para Madeira (Wood Screw)}

Segundo as informações do FOREST PRODUCTS LABORATORY (1999), os parafusos de fenda para madeira são usualmente produzidos em aço, bronze, níquel, cromo, cádmio e ligas metálicas. Seu comprimento varia de 6,35 a 152,4 mm. Estes parafusos possuem um sistema de padronagem, ou gauge, que consiste na variação do comprimento do parafuso para um mesmo diâmetro. Isto é indicado utilizando-se uma numeração que varia de 0 para os menores comprimentos de parafusos a 24 para os maiores comprimentos.

Os parafusos de fenda para madeira (wood screws) possuem rosca em cerca de 2/3 do seu comprimento, sendo classificados de acordo com a finalidade de uso, material de fabricação e a forma da cabeça.

Os parafuso de fenda para madeira são utilizados para fixar peças pouco espessas ou peças submetidas a pequenos esforços. Os tipos comuns deste parafuso são freqüentemente encontrados com cabeça plana, oval e redonda. $\mathrm{O}$ modelo de parafuso que possui cabeça plana é utilizado onde se deseja um acabamento nivelado com a superfície. O modelo de parafuso que possui cabeça oval é indicado para acabamentos aparentes enquanto o modelo de parafuso que possui cabeça redonda é utilizado para acabamento escareado. Estes modelos podem ser observados na figura 2.1. 


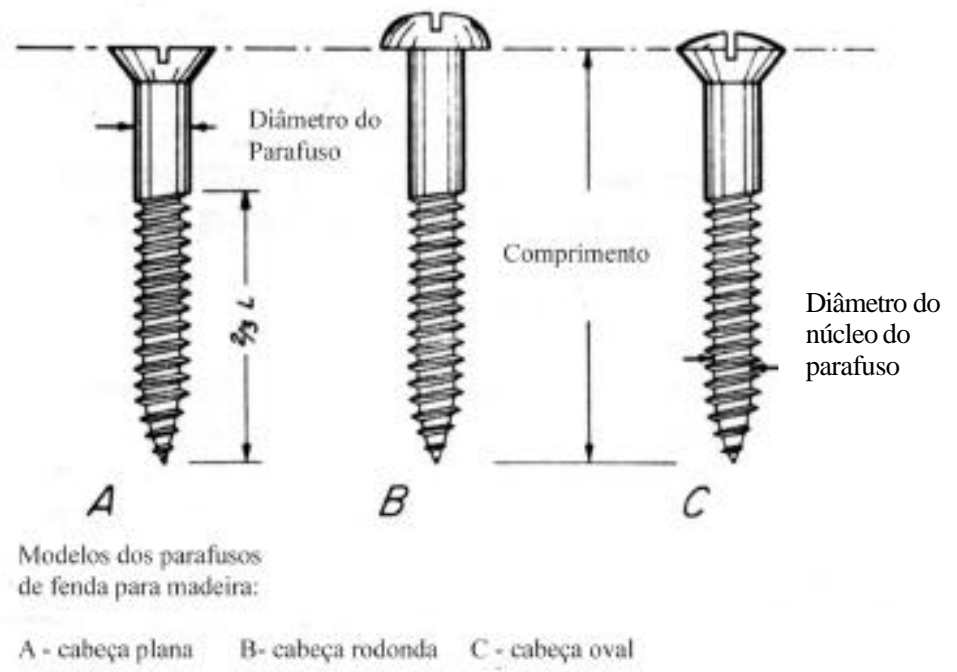

Figura 2.1- Modelos de parafusos de fenda para madeira. FONTE: FOREST PRODUCTS LABORATORY (1999).

\subsection{2 - Parafuso Auto-atarraxante (Lag Screw)}

Segundo as informações do FOREST PRODUCTS LABORATORY (1999), o parafuso auto-atarraxante (lag screw) também é conhecido como parafuso sextavado com rosca soberba. Este tipo de parafuso apresenta as seguintes dimensões: entre 5,08 a 25,4 mm para o diâmetro e seu comprimento variando entre 25,4 a 406,4 mm. O aço utilizado para a fabricação destes parafusos possui tensão de escoamento em torno de $310 \mathrm{MPa}$ e máxima tensão de ruptura igual a $530 \mathrm{MPa}$. Na figura 2.2, pode-se observar um parafuso sextavado com rosca soberba.

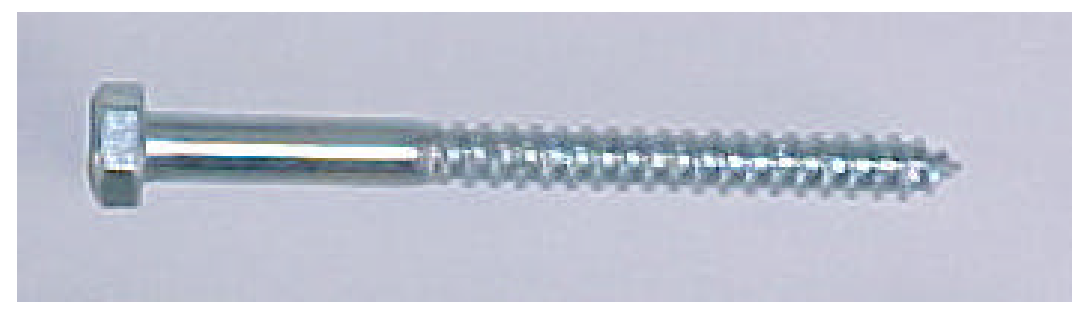

Figura 2.2 - Parafuso sextavado com rosca soberba.

Este modelo de parafuso é geralmente utilizado para fixar peças mais robustas, sendo submetido a esforços de cisalhamento ou a uma combinação de esforços de cisalhamento e arrancamento. 
No comércio brasileiro, não é possível encontrar parafusos auto-atarraxantes com todas as dimensões enunciadas. O diâmetro varia entre 2,2 e $10 \mathrm{~mm}$ e o comprimento entre 10 e 130 mm. Usualmente são fabricados em aço carbono SAE 1010/1020 e aço inox AISI 304/316. Mas é possível fazer-se encomendas junto aos fabricantes especificando as dimensões e o material a ser utilizado na fabricação dos parafusos auto-atarraxantes especiais.

No presente trabalho será avaliado um modelo específico, o parafuso torx autoatarraxante, mostrado na figura 2.3 .

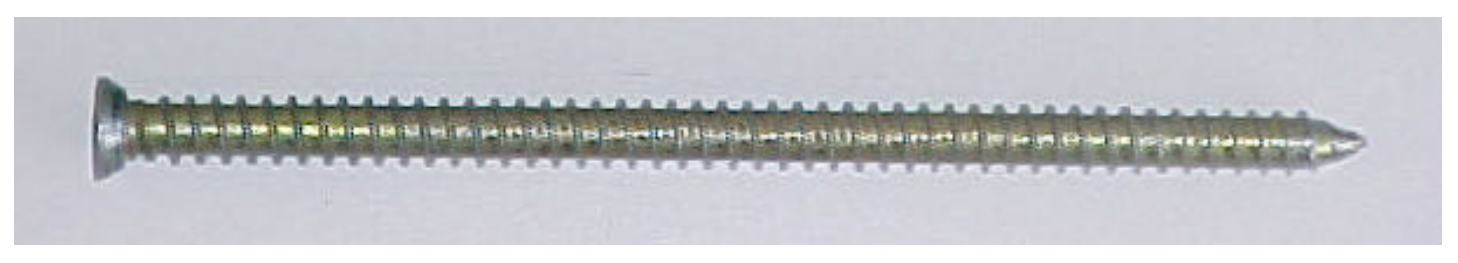

Figura 2.3 - Parafuso torx auto-atarraxante.

O parafuso torx auto-atarraxante é diferente dos demais modelos de parafusos 'lag screw". Este tipo de parafuso é fabricado com aço temperado, em diversos comprimentos para um mesmo diâmetro, possuindo rosca em todo o seu comprimento. Sua cabeça possui fenda tipo Torx apropriada para utilização de parafusadeira.

\section{2 - EXEMPLOS DE APLICAÇÃO DOS PARAFUSOS TORX AUTO-ATARRAXANTES}

MISCHLER (2000) desenvolve a possibilidade de utilização dos parafusos torx autoatarraxantes como reforço estrutural ou como uma conexão. As maneiras de fixação dos parafusos seriam paralelos às fibras, perpendiculares às fibras ou em ângulo de $45^{\circ}$.

Neste artigo, o autor aponta como vantagens da utilização do parafuso torx autoatarraxante a simplicidade da ligação e a rapidez de execução, bem como a grande resistência obtida nas ligações. Um exemplo de uma montagem estrutural é apresentado na figura 2.4 . 


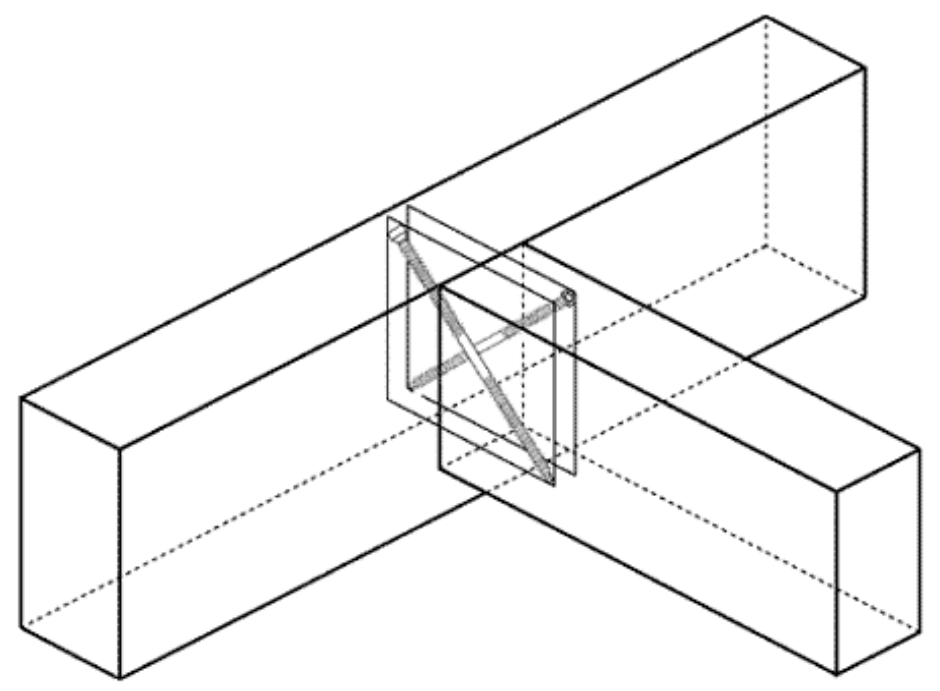

Figura 2.4 - Exemplo de ligação típica utilizando parafusos torx auto-atarraxantes.

FONTE: MISCHLER (2000).

Esta ligação pode ser feita através de entalhe na viga principal, originando uma ligação esteticamente atraente. Assim, para ligações submetidas a esforços de maior magnitude, este tipo de ligação é mais vantajoso.

São apresentados alguns resultados de ensaios utilizando protótipos de treliças com comprimento de 4,00 m e altura de 0,83 m. Os banzos possuíam seção de 6 x $12 \mathrm{~cm}$ e a diagonal, seção de $6 \times 6 \mathrm{~cm}$. As ligações entre os banzos e as diagonais foram feitas utilizando-se 4 parafusos com comprimento de $180 \mathrm{~mm}$. A resistência obtida na ligação foi de 9,45 kN por parafuso. Utilizando-se diagonais com seção de 6 x $8 \mathrm{~cm}$ e 6 parafusos, a resistência da ligação passou para $10,00 \mathrm{kN}$ por parafuso. As figuras 2.5 e 2.6 apresentam o protótipo da treliça e o modo de ruptura.

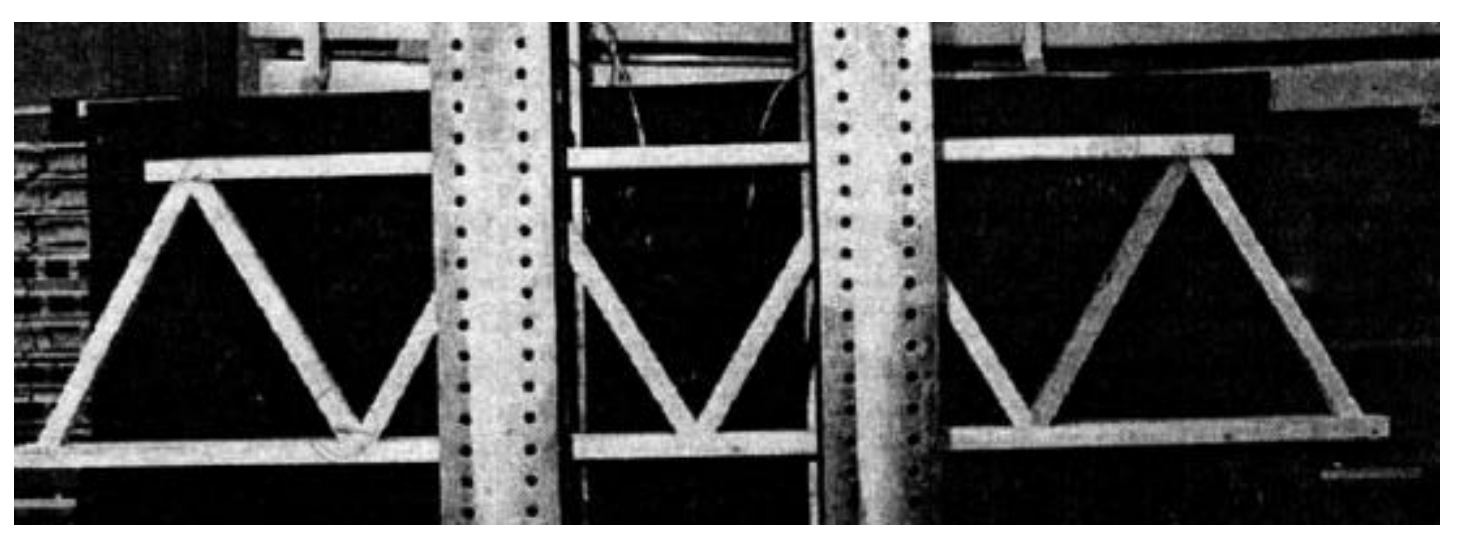

Figura 2.5 - Protótipo de treliça. FONTE: MISCHLER (2000). 


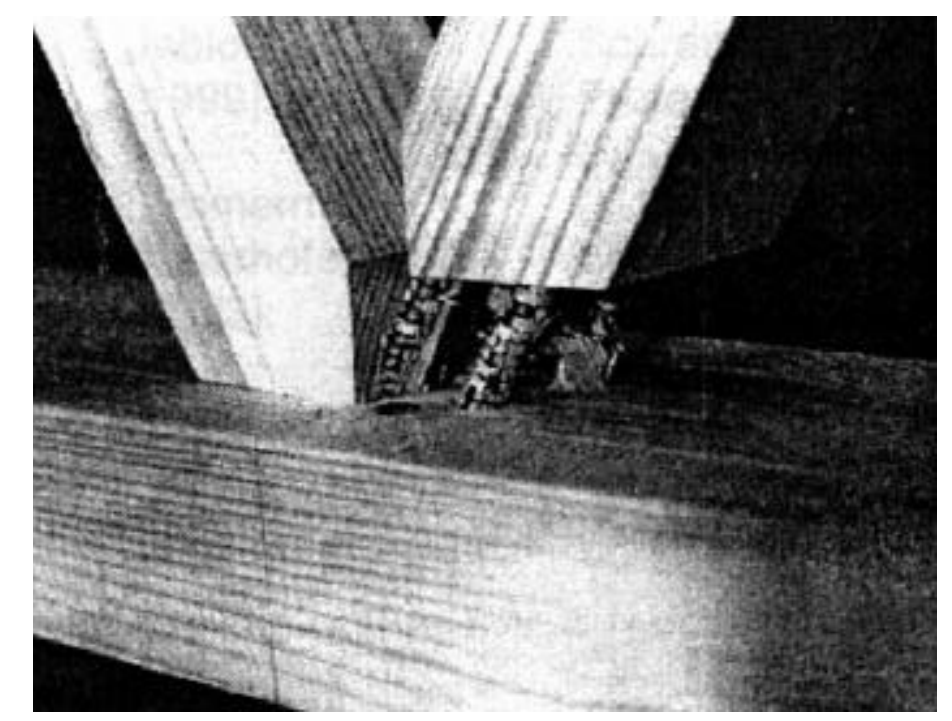

Figura 2.6 - Modo de ruptura da ligação. FONTE: MISCHLER (2000).

A SFS Holding AG é uma empresa que atua na construção civil. Esta empresa tem diversas inovações técnicas dentre elas os parafusos torx auto-atarraxantes. Foi desenvolvido um sistema denominado "WT" de ligações para estruturas de madeira, que possui como característica a grande facilidade na execução das ligações. As figuras 2.7 e 2.8 mostram exemplos da utilização dos parafusos torx auto-atarraxantes (SFS, 2002).

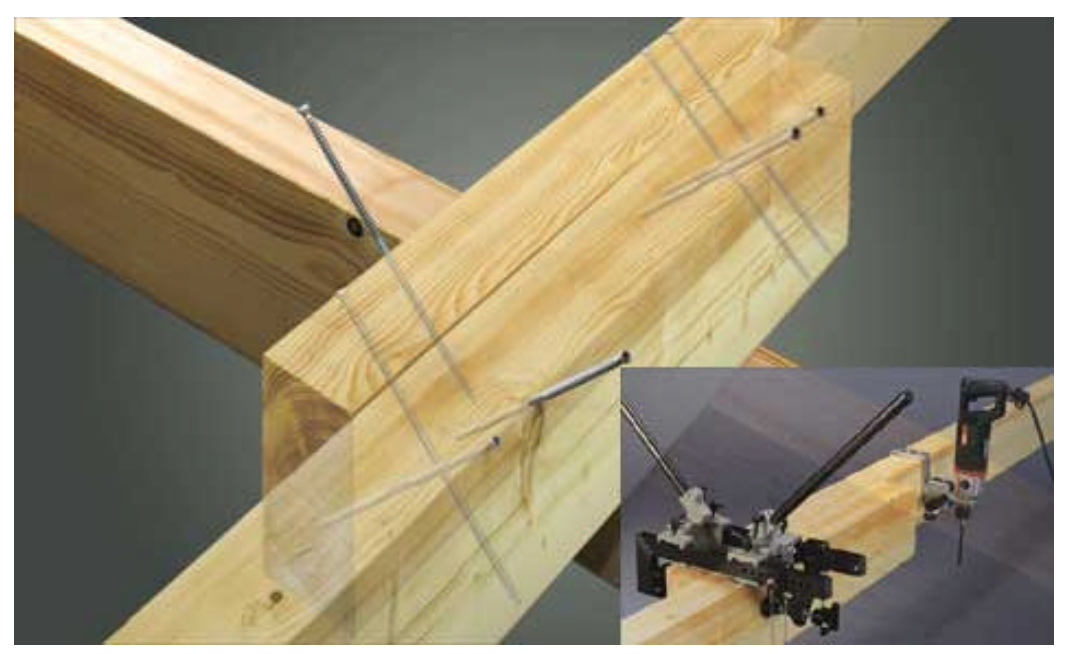

Figura 2.7 - Ligação com parafusos torx auto-atarraxantes. FONTE: SFS (2002). 

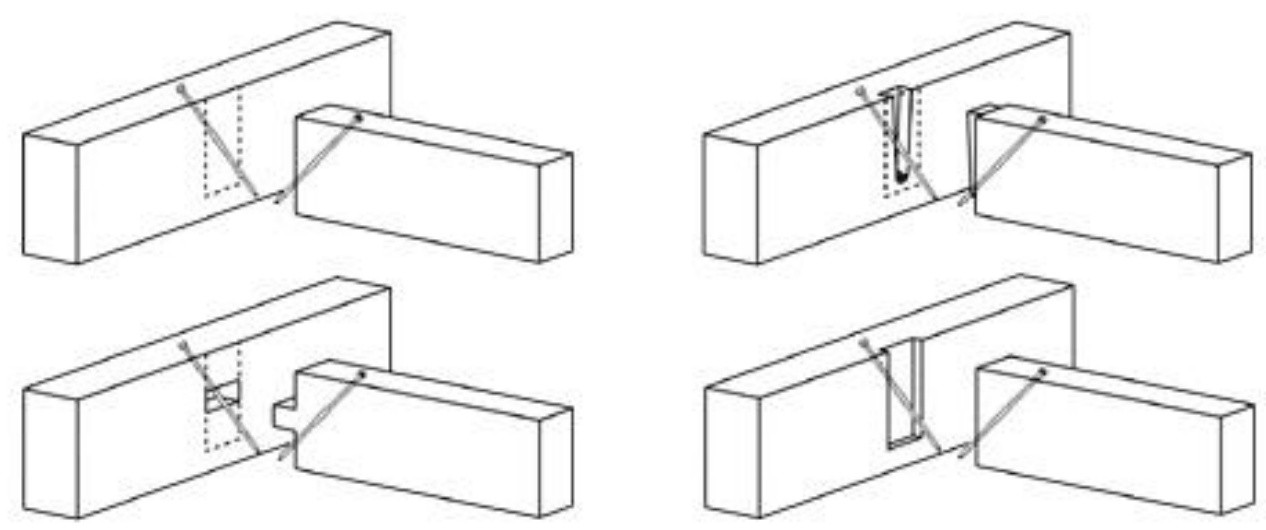

Figura 2.8 - Outras formas de ligação com parafuso torx auto-atarraxante. FONTE: SFS (2002).

Combinando-se o parafuso torx auto-atarraxante, uma base de fixação e a utilização de parafusadeira obtêm-se rapidez nos processos produtivos e garantia de segurança, mesmo para trabalhos em posições incômodas, sendo a fixação do parafuso feito com torque correto e em uma única operação, sem a necessidade de pré-furação. As figuras 2.9 e 2.10 apresentam o sistema "WT" de ligações para parafusos torx auto-atarraxantes.

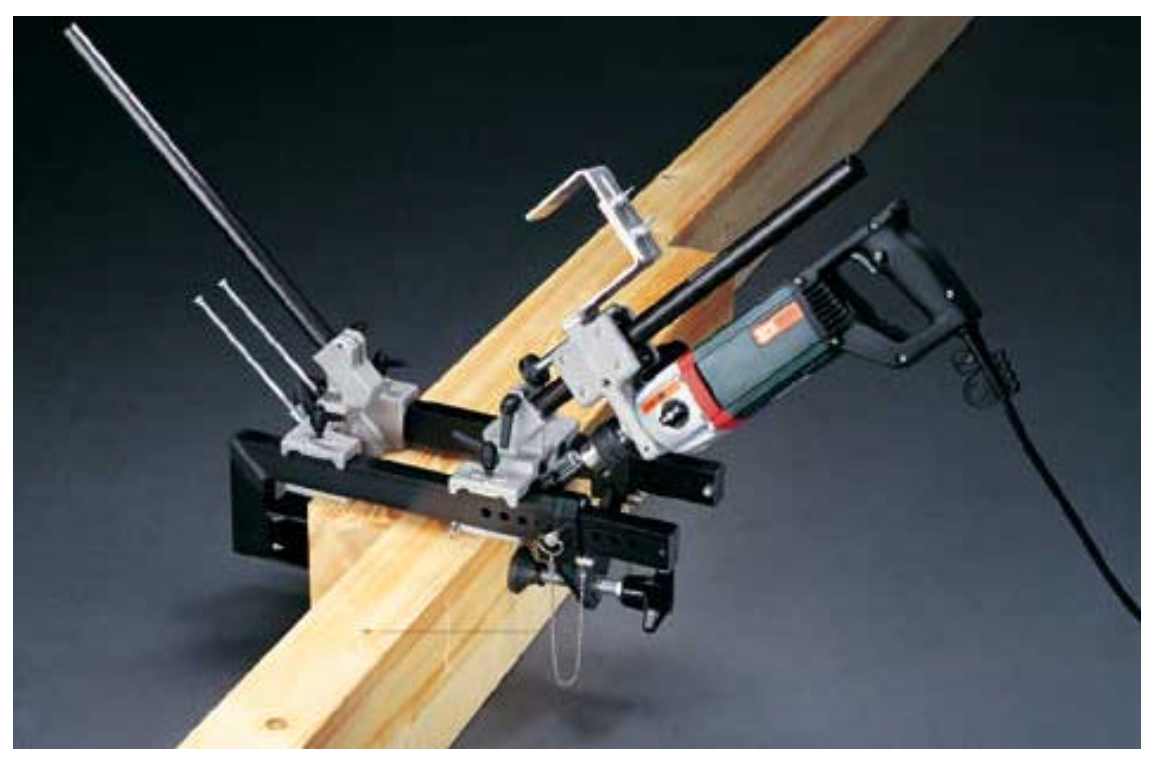

Figura 2.9 - Base de fixação para utilização da parafusadeira. FONTE: SFS (2002). 


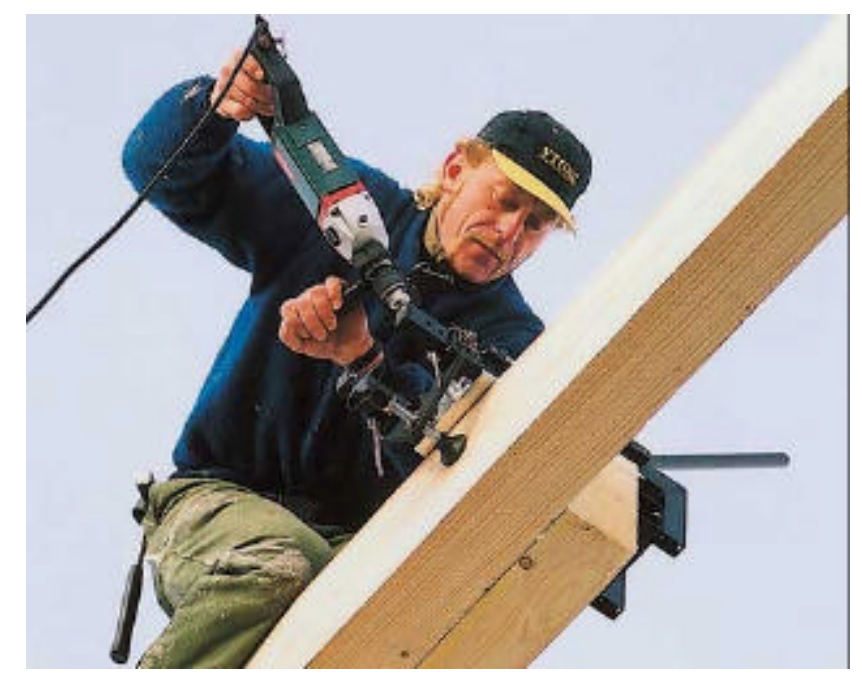

Figura 2.10 - Exemplo de utilização no canteiro de obras. FONTE: SFS (2002).

O posicionamento dos parafusos totalmente inseridos dentro da peça de madeira combina características estéticas aliadas à proteção e à resistência ao fogo, pois pode ser utilizado em situações críticas de segurança. A figura 2.11 apresenta a configuração dos parafusos posicionados nas vigas.

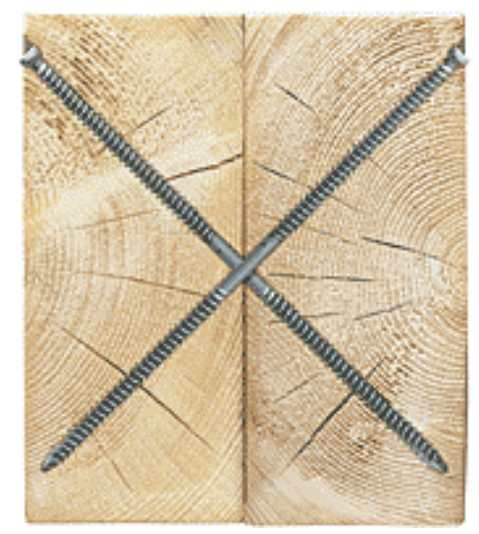

Figura 2.11 - Parafusos após sua fixação nas vigas. FONTE: SFS (2002).

\section{3 - ASPECTOS QUE INFLUENCIAM A RESISTÊNCIA DA LIGAÇÃO}

NEWLIN E GAHAGAN (1938) realizaram estudos sobre parafusos autoatarraxantes para melhorar os dados técnicos a respeito deste tipo de ligação com vistas à sua utilização em projetos. Seu estudo foi motivado pelo fato de não haver um consenso sobre os valores de resistência destes parafusos, naquela época. Os testes envolvidos neste 
estudo avaliaram a resistência dos parafusos submetidos a solicitações de tração e cisalhamento.

Os parafusos auto-atarraxantes utilizados nesta pesquisa possuíam rosca em $75 \%$ do comprimento do parafuso. Dentre as madeiras utilizadas encontravam-se espécies de baixa e alta densidade, na condição de umidade seca ao ar. Os resultados obtidos mostraram que, ao ocorrer uma variação na umidade em torno de $1 \%$, a variação de resistência difere em torno de $2 \%$.

Todo cuidado foi dado ao retirar os corpos-de-prova, com o objetivo de se eliminar qualquer defeito presente na madeira. Os corpos-de-prova apresentavam dimensões suficientes para que diversos diâmetros de parafusos fossem utilizados na mesma peça, evitando assim variações nos resultados da resistência para a mesma peça de madeira.

A velocidade do teste de tração do parafuso foi $1 \mathrm{~mm}$ por minuto. Os resultados obtidos indicaram a máxima resistência de tração. Outros ensaios foram realizados com o objetivo de determinar a umidade, a densidade e a resistência à compressão paralela às fibras dos corpos-de-prova.

Três grupos de testes forma realizados: um avaliando a eficiência da pré-furação para diferentes diâmetros de parafusos e diferentes espécies de madeiras; outro avaliando os efeitos da variação da profundidade de penetração de rosca; e o terceiro, avaliando as diferentes resistências obtidas ao variar os diâmetros dos parafusos, tanto fixos paralelos às fibras como fixos perpendiculares às fibras.

Com relação à pré-furação, esta deve ter o mesmo diâmetro do parafuso e a mesma profundidade de penetração na região sem rosca do parafuso. Já a pré-furação na porção que possui rosca deve ser a seguinte:

- Para madeiras do grupo 1, (densidade maior que 0,60 g/ $\mathrm{cm}^{3}$ ): 65 a $85 \%$ do diâmetro do parafuso.

- Para madeiras do grupo 2, (densidade entre 0,50 e 0,60 g/ $\mathrm{cm}^{3}$ ): 60 a 75\% do diâmetro do parafuso.

- Para madeiras dos grupos 3 e 4, (densidade menor que $\left.0,50 \mathrm{~g} / \mathrm{cm}^{3}\right): 40$ a $70 \%$ do diâmetro do parafuso.

A menor porcentagem é aplicada para parafuso com menor diâmetro e a maior porcentagem é aplicada para grandes diâmetros de parafusos. 
Os fatores que influenciam na resistência ao arrancamento direto dos parafusos são: o diâmetro da pré-furação, o comprimento de penetração de rosca do parafuso, a densidade da madeira e o diâmetro do parafuso. A figura 2.12 apresenta o comportamento das ligações submetidas a esforços de tração axial ao variar-se à profundidade de penetração de rosca nos corpos-de-prova.

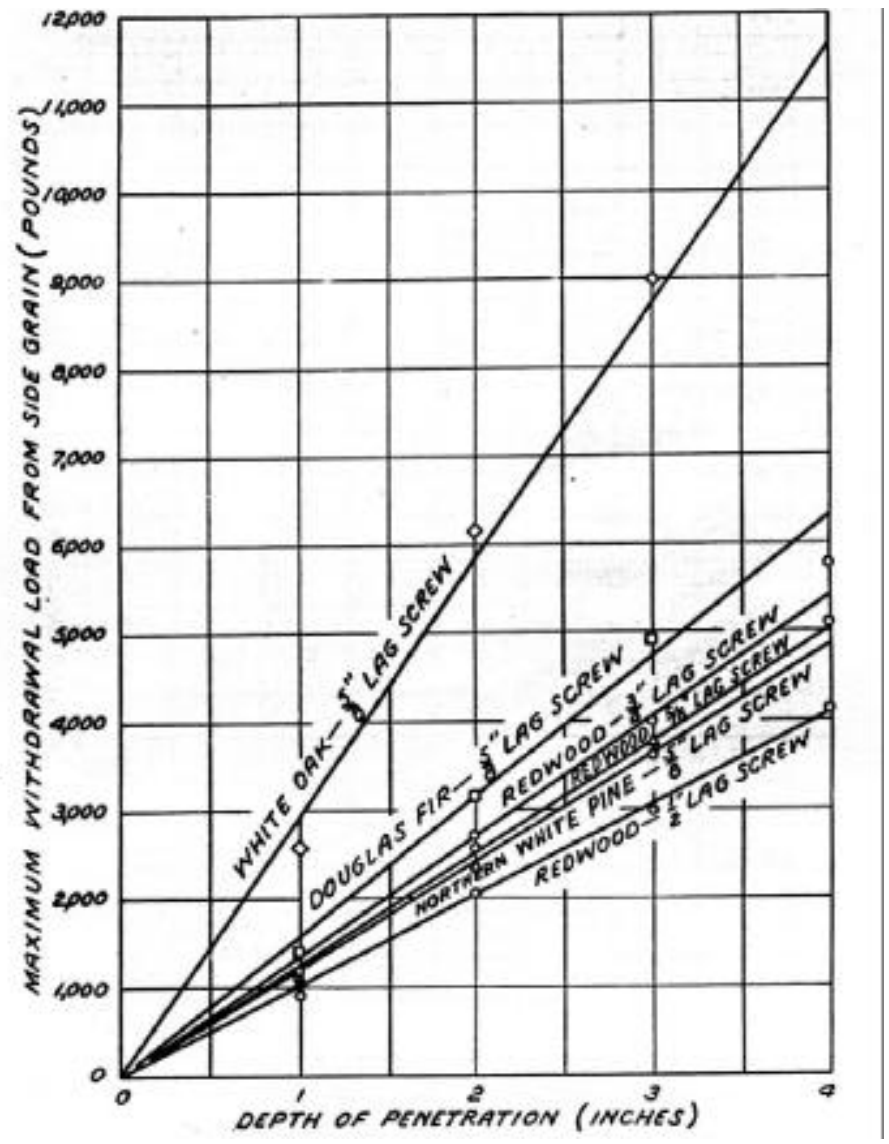

Figura 2.12 - Gráfico da resistência à tração utilizando parafusos auto-atarraxantes em diferentes profundidades de penetração. FONTE: NEWLIN e GAHAGAN (1938).

Observa-se que, para um determinado diâmetro de parafuso e espécie de madeira, a resistência à tração tende a ter um comportamento linear ao variar o comprimento de rosca inserida no corpo-de-prova. Desta forma, é comum apresentar a resistência à tração como sendo uma força por unidade de comprimento de rosca inserida.

Segundo os autores, dentre as propriedades que caracterizam a madeira, a densidade se mostrou como o melhor critério para avaliar a resistência ao arrancamento direto de parafusos auto-atarraxantes. A figura 2.13 apresenta o comportamento da resistência da ligação ao variar a densidade. Essa resistência varia, aproximadamente, com a potência de $3 / 2$ da densidade da madeira. 


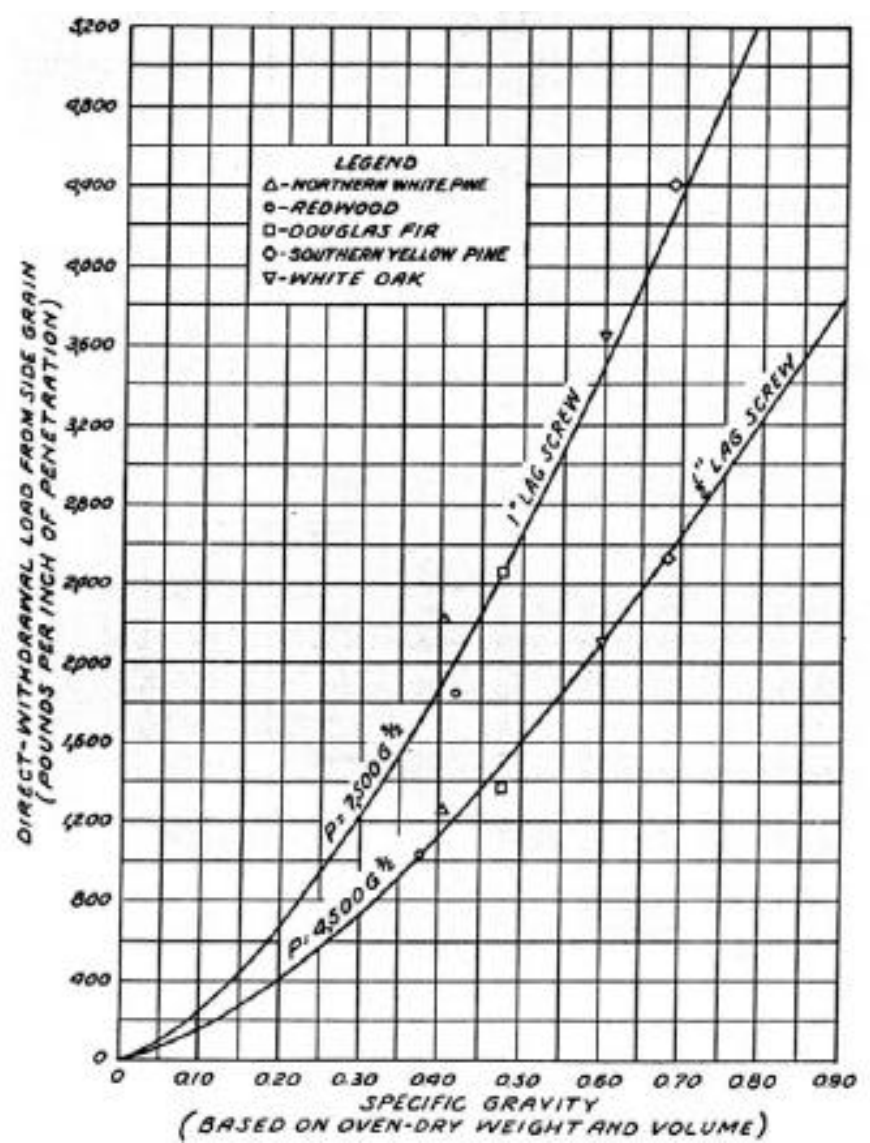

Figura 2.13 - Relação entre a resistência à tração para diferentes diâmetros de parafusos auto-atarraxantes e a densidade da madeira. FONTE: NEWLIN e GAHAGAN (1938).

A relação entre a resistência obtida para o arrancamento direto e os diâmetros dos parafusos é melhor definida pela potência de 3/4. Assim, a influência combinada do diâmetro do parafuso e a densidade da madeira pode ser expressa pela equação:

$$
\mathrm{R}_{90}=\mathrm{Kd}^{3 / 4} \rho^{3 / 2}
$$

onde:

$\mathrm{R}_{90}$ - Resistência máxima de tração na direção perpendicular às fibras, em lb/pol;

$\rho$ - Massa específica da madeira a $12 \%$ de umidade, em lb/pol ${ }^{3}$;

d - Diâmetro do parafuso, em pol;

$\mathrm{K}$ - constante igual a 7500. 
Por meio do método das tensões admissíveis, calcula-se a resistência admissível da ligação, que correspondente a $1 / 5$ do valor da resistência máxima de tração obtida pela equação 1 .

A figura 2.14 apresenta a relação entre a resistência à tração para diversos de diâmetros com relação à densidade da madeira. Com este gráfico, é possível estimar, de forma simplificada, a resistência à tração para os mais diversos diâmetros de parafusos e densidades.

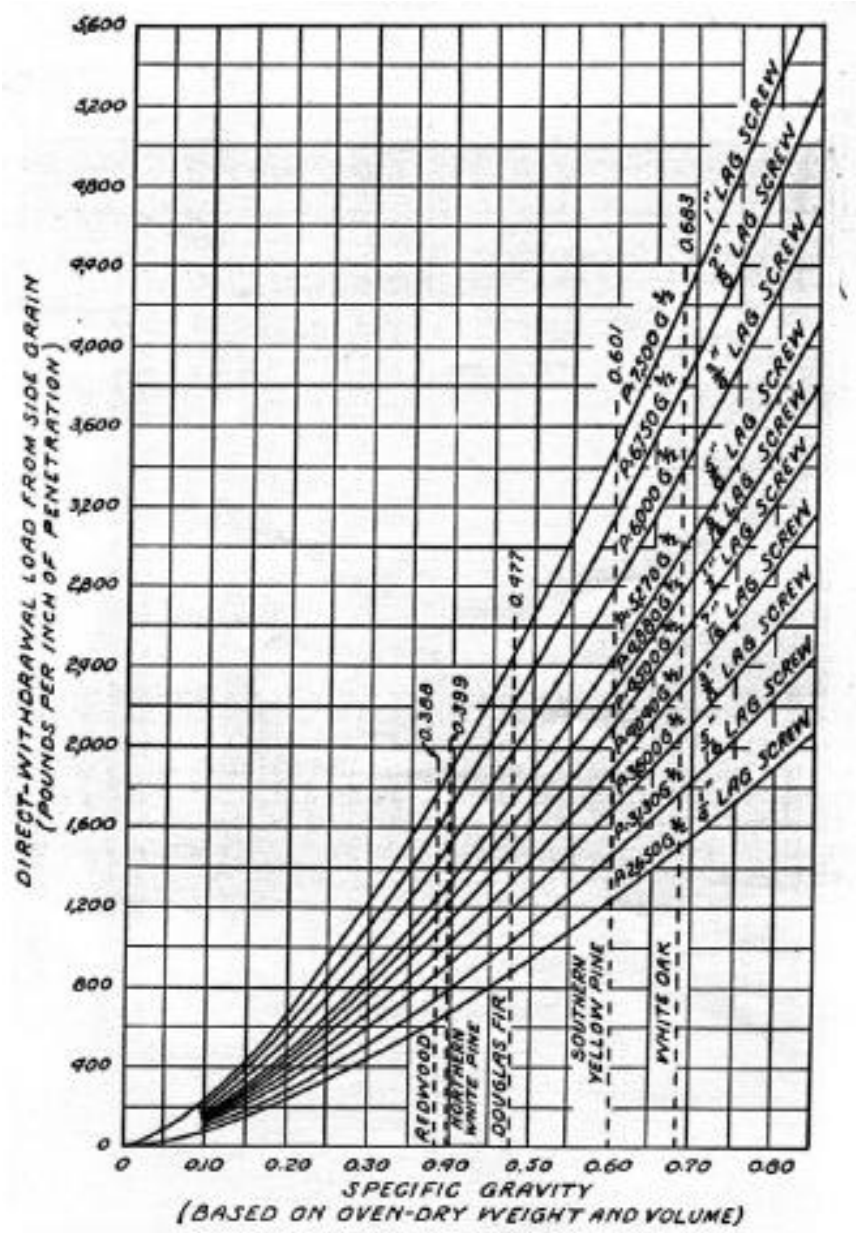

Figura 2.14 - Relação entre a resistência à tração x densidade. FONTE: NEWLIN e GAHAGAN (1938).

O valor da resistência para parafusos inseridos na direção paralela às fibras, corresponde a 75\% da obtida com os parafusos fixados na direção perpendicular às fibras.

Para que ocorra a máxima tensão de tração admissível na ligação, deve-se introduzir na madeira um comprimento de rosca igual a 7 vezes o diâmetro do parafuso, em espécies de 
alta densidade, e entre 10 e 12 vezes o diâmetro do parafuso, para espécies de baixa densidade. Para comprimentos de rosca maiores que os mencionados, não ocorrerá a ruptura da ligação, mas sim a ruptura do parafuso.

FREIRER (1963) indica que os parafusos de fenda para madeira podem estar sujeitos a dois tipos de solicitação: tração e cisalhamento. Para este tipo de parafuso, deve-se fazer duas pré-furações: uma para a região do fuste e outra para a região da rosca.

Para ambas as solicitações, a pré-furação na região do fuste deve ser igual a 7/8 do diâmetro do parafuso. A pré-furação na região da rosca deve ser igual a $60 \%$ do diâmetro do núcleo do parafuso (quando solicitado a cisalhamento) e $50 \%$ do diâmetro do núcleo do parafuso (quando solicitado por tração).

Deve-se ter muito cuidado para não danificar a madeira no momento do atarraxamento, pois isto pode causar uma menor eficiência da ligação.

Ao unir duas peças de madeira, deve-se introduzir entre $2 / 3$ a todo comprimento de rosca na peça de madeira principal da ligação, como é indicado na figura 2.15. Isto tem como objetivo proporcionar uma maior eficiência da ligação entre as duas peças.

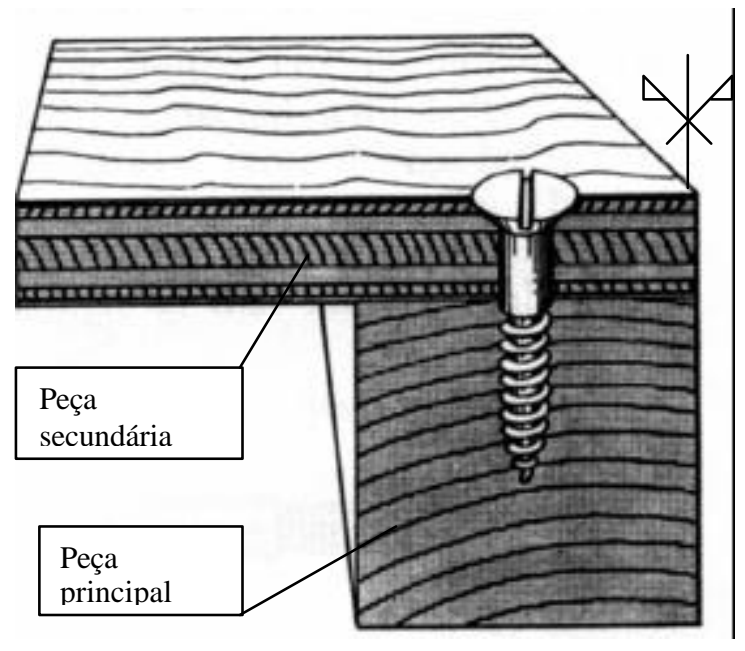

Figura 2.15 - Exemplo de ligação. FONTE: FREIRER (1963).

BREYER (1980) apresenta alguns fatores que afetam a resistência das ligações. Dentre os fatores, é citado a espécie da madeira (densidade). Para a pré-furação, utiliza-se na região sem rosca o equivalente ao diâmetro do parafuso; na região que possui rosca, a pré-furação será dada como sendo uma porcentagem do diâmetro do fuste, apresentada a seguir: 


$$
\begin{aligned}
& \text { Madeiras do Grupo } 1-\mathrm{d}_{2}=(0,65 \text { a } 0,85) \text { x d } \\
& \text { Madeiras do Grupo } 2-\mathrm{d}_{2}=(0,60 \text { a } 0,75) \text { x d } \\
& \text { Madeiras do Grupo } 3 \text { e } 4-\mathrm{d}_{2}=(0,40 \text { a } 0,70) \text { x d }
\end{aligned}
$$

onde:

$\mathrm{d}_{2}$ - é o diâmetro da pré-furação

d - é o diâmetro do parafuso

Segundo este autor, outro fator que afeta a resistência da ligação é a direção de fixação dos parafusos em relação às fibras da madeira. Não se recomenda a execução de ligações solicitadas por esforços de tração com os parafusos fixos paralelos às fibras da madeira. Caso não seja possível montar a ligação de maneira diferente, deve-se utilizar somente $75 \%$ do valor da solicitação obtida para o parafuso fixo perpendicular às fibras da madeira. Isto é devido ao fato da madeira poder se encontrar com um alto teor de umidade e tender a sofrer pequenas rachaduras ao secar, interferindo na resistência da ligação.

VAZ (1987) apresentada uma análise da utilização dos parafusos auto-atarraxantes em silos verticais de madeira. Os aspectos principais do uso e das ações nos parafusos autoatarraxantes são: a resistência ao arrancamento direto e a resistência ao deslocamento lateral.

As ligações com parafusos auto-atarraxantes, entre peças de madeira ou entre peças metálicas, são geralmente utilizadas devido à sua conveniência e, sobretudo, em locais onde a fixação de parafusos comuns com porcas e arruelas é difícil ou inadequada. Estas ligações normalmente se caracterizam pela presença de dois membros, um principal, sempre de madeira, onde penetram a ponta e a parte rosqueada do parafuso, e outro secundário (cobrejunta), fixado ao bloco pelos parafusos. A cobrejunta poderá ser de madeira ou metálica conforme a figura 2.16 .

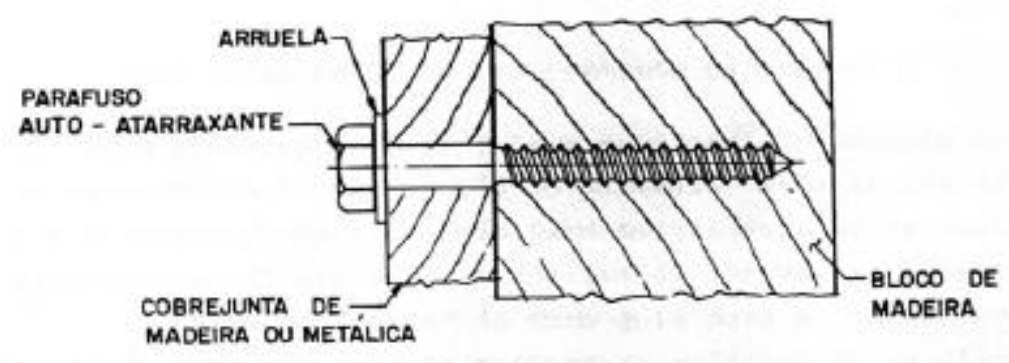

Figura 2.16 - Ligação com parafuso auto-atarraxante. FONTE: VAZ (1987). 
O método empregado para a realização dos ensaios de tração utilizou corpos-deprova com dimensões de 6 × 6 × $12 \mathrm{~cm}$ em peças de Peroba Rosa (Aspidosperma polyneuron muell. Arg.) e parafusos auto-atarraxantes com diâmetro de 6,35 mm e comprimento de $60 \mathrm{~mm}$. Segundo o autor, estas dimensões garantem a fixação desejada e os afastamentos mínimos das bordas. Em todos os testes, utilizou-se somente um parafuso fixo com sua parte rosqueada completamente inserida na madeira, o que corresponde a $38,1 \mathrm{~mm}$ ou 6 diâmetros nominais. A figura 2.17 apresenta a configuração dos corpos-de-prova.

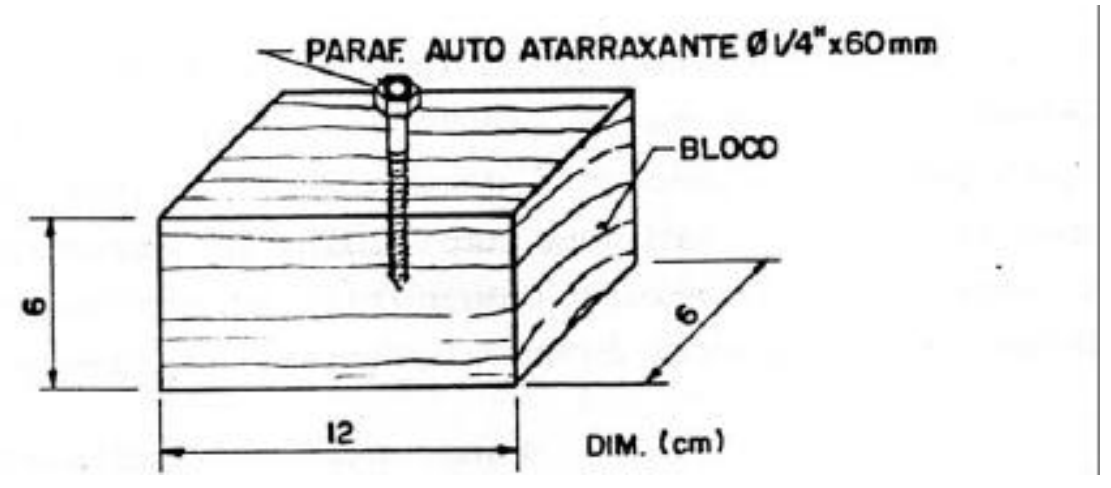

Figura 2.17 - Método de ensaio para arrancamento direto. FONTE: VAZ (1987).

Com relação à pré-furação, adotou-se por meio de tentativas o correspondente a $71 \%$ do diâmetro do parafuso, o que corresponde a $4,5 \mathrm{~mm}$. A velocidade de arrancamento foi mantida em torno de $1 \mathrm{~mm}$ por minuto.

Os resultados apresentados indicam valores equivalentes de resistência tanto para os parafusos fixos paralelamente ou perpendicularmente às fibras, devido ao fato de ter ocorrido à ruptura do parafuso e não na ligação entre este e a madeira.

Com relação à resistência obtida na ligação, é feita uma comparação. Segundo a NBR 7190/82 - "Cálculo e Execução de Estruturas de Madeira", a carga admissível da ligação deve ser igual a $20 \%$ do limite de resistência. Para as ligações em estudo, tem-se uma resistência média de $9,62 \mathrm{kN}$; portanto a carga admissível, calculada pelos parâmetros da NBR 7190/82, utilizando-se peças de madeira (Peroba Rosa), tem valor médio em torno de 1,92 kN. O valor de resistência obtida através de cálculo baseado nos estudo de NEWLIN e GAHAGAN, adotando-se o coeficiente de segurança previsto, resultará em uma carga admissível de 2,77 kN. Para o método de cálculo previsto pelo NATIONAL FOREST PRODUCTS ASSOCIATION, a carga admissível é de 2,62 kN. 
Vaz (1987) concluiu que as duas referências utilizadas em seu estudo apresentam valores de resistências discutíveis para sua aplicação em ligações que utilizem madeiras nacionais, visto terem conduzido a valores superiores aos obtidos através dos ensaios. Salientou, entretanto, que sempre ocorreu à ruptura do parafuso, enquanto que os critérios citados são referentes à ligação.

MCLAIN (1997) fez uma análise das equações apresentadas na NDS-91 NATIONAL DESIGN SPECIFICATION FOR WOOD CONSTRUCTION (1991). Os valores da força de tração estão relacionados com a densidade da madeira e o diâmetro do parafuso. Estas equações foram desenvolvidas no U.S. FOREST SERVICE, provavelmente durante as décadas de 30 ou 40 do século findo. Neste artigo, são apresentados os tipos de ruptura que podem ocorrer em uma ligação, dentre as quais salienta: deslizamento da rosca do parafuso com relação ao corpo de madeira e a falha causada pela ruptura do parafuso.

Segundo MCLAIN (1997), as equações apresentadas na NDS - 91 para o cálculo da força máxima de tração para parafusos auto-atarraxante são:

- Parafuso de fenda para madeira (wood screw)

$$
\mathrm{R}_{90}=98,1 \cdot \mathrm{d} \cdot \rho^{2} \cdot \mathrm{L}_{\mathrm{RE}}
$$

- Parafuso sextavado com rosca soberba (lag screw)

$$
\mathrm{R}_{90}=116 \cdot d^{0,75} \cdot \rho^{1,5} \cdot \mathrm{L}_{\mathrm{RE}}
$$

onde:

$\mathrm{R}_{90}$ - Resistência máxima de tração na direção perpendicular às fibras, em N;

d - Diâmetro do parafuso, em mm;

$\rho$ - Massa específica da madeira a $12 \%$ de umidade, em $\mathrm{g} / \mathrm{mm}^{3}$;

$\mathrm{L}_{\mathrm{RE}}$ - Comprimento de rosca efetivo na peça principal de madeira, em $\mathrm{mm}$.

Ao observar as equações anteriores, cabe uma explicação a respeito do comprimento de rosca efetivo. Esta dimensão corresponde ao comprimento de rosca que efetivamente contribui para a resistência, ou seja, é o comprimento de rosca inserida na peça principal de madeira menos o comprimento da região cônica da ponta do parafuso. 
Para calcular a força de tração admissível em projeto, utiliza-se a seguinte equação:

$$
\mathrm{R}_{\mathrm{ad}}=1,20 \cdot \mathrm{R}_{90} / \mathrm{SF}
$$

onde:

$\mathrm{R}_{\mathrm{ad}}$ - Resistência de tração nominal admissível;

1,20 - Fator de ajuste para solicitação normal ou 10 anos de solicitação normal;

SF - Fator de segurança, com valor de 6 para o parafuso de fenda para madeira e o valor de 5 para o parafuso sextavado c/ rosca soberba.

Com o desenvolvimento de seu trabalho, MCLAIN (1997) fez uma análise utilizando um modelo de regressão não linear, obtendo as seguintes equações:

- Para o parafuso de fenda para madeira:

$$
\mathrm{R}_{90}=110 \cdot \mathrm{d}^{0,82} \cdot \rho^{1,77}
$$

- Para o parafuso sextavado com rosca soberba:

$$
R_{90}=185 \cdot d^{0,61} \cdot \rho^{1,35}
$$

onde:

$\mathrm{R}_{90}$ - Resistência máxima de tração na direção perpendicular às fibras, em N;

d - Diâmetro do parafuso, em mm;

$\rho$ - Massa específica da madeira a $12 \%$ de umidade, em $\mathrm{g} / \mathrm{mm}^{3}$.

MCLAIN (1997) sugeriu que as equações 8 e 9 substituíssem as equações da NDS - 91. Estas equações são baseadas no método das tensões admissíveis. Este método de cálculo possui coeficiente de segurança com valor igual a 5 para os parafusos sextavados $\mathrm{c} /$ rosca soberba (lag screw) e coeficiente de segurança igual a 6 para os parafusos de fenda para madeira (wood screw). Ao observar esta diferença, MCLAIN (1997) sugere que seria melhor utilizar um único fator de segurança por volta de 5,5 com o objetivo de facilitar o desenvolvimento dos cálculos para as ligações.

Ao comparar as equações 5 e 6 com as equações 8 e 9, estas últimas apresentam resultados mais consistentes. Ao fazer uso das equações 5 e 6 para parafusos com pequeno 
diâmetro e baixa densidade, os resultados apresentam valores menores em relação às equações 8 e 9. Para a situação oposta, isto é, parafusos com grande diâmetro e alta densidade da madeira, obtêm-se resultados maiores. Isso pode ser observado na figura 2.18.

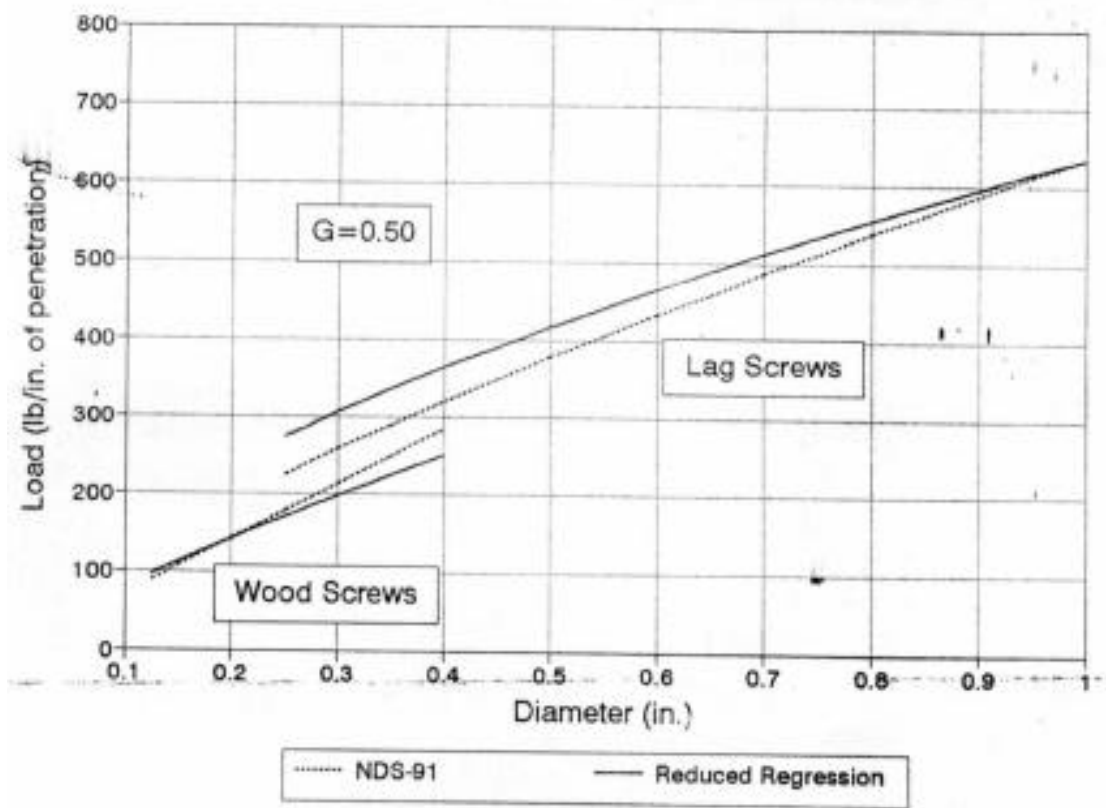

Figura 2.18 - Gráfico comparativo entre as equações. FONTE: MCLAIN (1997).

\section{4 - NORMATIZAÇÃO E CRITÉRIOS DE DIMENSIONAMENTO}

\subsection{1 - DEUSTCHES INSTITUT FÜR NURMING (1988)}

A norma alemã DIN 1052 - STRUCTURAL USE OF TIMBER do DEUSTCHES INSTITUT FÜR NURMING (1988), estabelece o cálculo da força de tração admissível para parafusos auto-atarraxantes, para madeira seca ao ar, por meio da seguinte equação:

$$
\mathrm{R}_{\mathrm{ad}}=3 \cdot \mathrm{L}_{\mathrm{R}} \cdot \mathrm{d}
$$

onde:

$\mathrm{R}_{\mathrm{ad}}$ - Resistência de tração nominal admissível, em N;

$\mathrm{L}_{\mathrm{R}}$ - Comprimento de rosca inserida na peça principal de madeira, em mm; d - Diâmetro do parafuso, em mm. 
A pré-furação deve ser feita da seguinte maneira: na região sem rosca do parafuso, a pré-furação da madeira deve ser igual ao diâmetro nominal do parafuso, e na região com rosca, a pré-furação da madeira deve ser igual a 70\% do diâmetro nominal do parafuso.

As especificações relacionadas com ligações de parafusos auto-atarraxantes determinam a utilização de um diâmetro nominal mínimo de $4 \mathrm{~mm}$. A profundidade de penetração da rosca deve estar entre 4 a 12 diâmetros nominais. As recomendações citadas são para parafusos auto-atarraxantes que atendem às normas DIN 96 e DIN 97.

Com relação aos espaçamentos mínimos, existem as seguintes recomendações para parafusos submetidos a esforços de cisalhamento:

- Espaçamento entre parafusos:

Paralelo às fibras $\quad 5 \mathrm{~d}$

Perpendicular às fibras $5 \mathrm{~d}$

- Espaçamento da borda sofrendo carregamento:

Paralelo às fibras $\quad 10 \mathrm{~d}$

Perpendicular às fibras $5 \mathrm{~d}$

- Espaçamento da borda não sofrendo carregamento:

Paralelo às fibras $\quad 5 \mathrm{~d}$

Perpendicular às fibras $3 \mathrm{~d}$

\subsection{2 - AMERICAN NATIONAL STANDARD (1991)}

A norma norte-americana NDS-91 - NATIONAL DESIGN SPECIFICATION FOR WOOD CONSTRUCTION do AMERICAN NATIONAL STANDARD (1991) possui uma série de informações a respeito da utilização dos mais diversos tipos de conexões, incluindo-se os parafusos auto-atarraxantes (lag screws) em estruturas de madeira. Dentre as informações, constam as seguintes recomendações para a pré-furação:

1. A pré-furação deve ter o mesmo diâmetro do parafuso e a mesma profundidade de penetração da parte do parafuso sem rosca.

2. A pré-furação na porção de rosca deve ser a seguinte:

Para madeiras do grupo 1 (densidade maior que $0,60 \mathrm{~g} / \mathrm{cm}^{3}$ ): 65 a $85 \%$ do diâmetro do parafuso. 
Para madeiras do grupo 2 (densidade entre 0,50 e $0,60 \mathrm{~g} / \mathrm{cm}^{3}$ ): 60 a $75 \%$ do diâmetro do parafuso.

Para madeiras dos grupos 3 e 4 (densidade menor que $0,50 \mathrm{~g} / \mathrm{cm}^{3}$ ): 40 a $70 \%$ do diâmetro do parafuso.

3. Para parafusos com diâmetros menores que $9,52 \mathrm{~mm}$ e espécies com densidades menores que $0,50 \mathrm{~g} / \mathrm{cm}^{3}$ não há necessidade de se fazer a pré-furação, desde que mantidos as distâncias mínimas e os espaçamentos.

Os parafusos devem ser fixados com ferramenta apropriada, dependendo do tipo de cabeça. Nunca fazer o uso de martelo, para evitar danos à madeira situada em torno da rosca, o que diminui em muito a resistência da ligação. Os parafusos utilizados devem estar em conformidade com a norma ANSI/ASME Standard B18.2.1-1981(Reference 3).

Os valores nominais de resistência à tração estão tabelados e apresentados em libras por polegada de rosca inserida na madeira, sendo que os valores dados são para os parafusos inseridos perpendiculares às fibras da madeira. A tabela 2.1 apresenta alguns valores nominais de resistência à tração, convertidos para Newton por milímetro. No caso de tração paralela às fibras, os valores adotados em projeto devem ser multiplicados pelo fator $\mathrm{C}_{\mathrm{eg}}=$ 0,75 .

Tabela 2.1 - Resistência nominal à tração utilizando parafusos auto-atarraxantes em (N/mm).

\begin{tabular}{|c|c|c|c|c|c|}
\hline $\begin{array}{c}\text { Massa específica } \\
\left(\mathrm{g} / \mathrm{cm}^{3}\right)\end{array}$ & \multicolumn{5}{|c|}{ Diâmetro do parafuso } \\
\cline { 2 - 6 } & $1 / 4^{\prime \prime}$ & $\begin{array}{c}5 / 16^{\prime \prime} \\
(6,35 \mathrm{~mm})\end{array}$ & $\begin{array}{c}3 / 8^{\prime \prime} \\
(7,94 \mathrm{~mm})\end{array}$ & $\begin{array}{c}7 / 16^{\prime \prime} \\
(9,53 \mathrm{~mm})\end{array}$ & $\begin{array}{c}1 / 2 " \\
(11,11 \mathrm{~mm})\end{array}$ \\
\hline$(12,70 \mathrm{~mm})$
\end{tabular}

Estes valores devem ser multiplicados por fatores de ajuste com o objetivo de se obter os valores de projeto admissíveis das ligações, tais como:

- Fator de duração de carregamento;

- Fator de umidade de serviço, que leva em consideração o ambiente onde a ligação será exposta;

- Fator de temperatura, que leva em consideração a ligação exposta a altas temperaturas. 
Com relação aos espaçamentos, existem recomendações para parafusos submetidos a esforços de cisalhamento. Quando o espaçamento for menor que o mínimo requerido, deve-se utilizar um fator redutor $\left(\mathrm{C}_{\Delta}\right)$ do carregamento atuante. Para conexões com múltiplos cisalhamentos ou três membros assimétricos aplica-se o fator redutor para todos os parafusos. Os espaçamentos recomendados são apresentados nas tabelas 2.2 a 2.5.

Tabela 2.2 - Distância requerida à borda lateral

\begin{tabular}{|c|c|c|}
\hline \multicolumn{2}{|c|}{ Direção do carregamento } & Distância mínima \\
\hline \multirow{2}{*}{ Paralelo às fibras } & Quando $\mathrm{L}_{\mathrm{p}, \mathrm{s}} / \mathrm{d} \leq 6$ & $1,5 \mathrm{~d}$ \\
\cline { 2 - 3 } & Quando $\mathrm{L}_{\mathrm{p}, \mathrm{s}} / \mathrm{d}>6$ & $\begin{array}{c}1,5 \mathrm{~d} \text { ou } 1 / 2 \text { distância entre } \\
\text { fileiras, o que for maior. }\end{array}$ \\
\hline \multirow{2}{*}{ Perpendicular às fibras } & Carregando a borda & $4 \mathrm{~d}$ \\
\cline { 2 - 3 } & Descarregando a borda & $1,5 \mathrm{~d}$ \\
\hline
\end{tabular}

Tabela 2.3 - Distância requerida ao fim da peça

\begin{tabular}{|c|c|c|}
\hline \multirow[t]{2}{*}{ Direção do carregamento } & \multicolumn{2}{|c|}{ Distância mínima } \\
\hline & \multirow{2}{*}{$\begin{array}{c}\text { Com fator } \\
\text { redutor }\end{array}$} & \multirow{2}{*}{$\begin{array}{l}\text { Sem fator } \\
\text { redutor }\end{array}$} \\
\hline Paralelo às fibras & & \\
\hline Sofrendo compressão & $2 \mathrm{~d}$ & $4 d$ \\
\hline Sofrendo tração - Madeira de baixa densidade & $3,5 \mathrm{~d}$ & $7 \mathrm{~d}$ \\
\hline Sofrendo tração - Madeira de alta densidade & $2,5 \mathrm{~d}$ & $5 d$ \\
\hline Perpendicular às fibras & $2 \mathrm{~d}$ & $4 d$ \\
\hline
\end{tabular}

Tabela 2.4 - Distância requerida entre parafusos

\begin{tabular}{|c|c|c|}
\hline \multirow{2}{*}{ Direção do carregamento } & \multicolumn{2}{|c|}{ Distância mínima } \\
\cline { 2 - 3 } & Com fator redutor & Sem fator redutor \\
\hline Paralelo às fibras & $3 \mathrm{~d}$ & $4 \mathrm{~d}$ \\
\hline Perpendicular às fibras & $3 \mathrm{~d}$ & $4 \mathrm{~d}$ \\
\hline
\end{tabular}


Tabela 2.5 - Espaçamento entre fileiras de parafusos

\begin{tabular}{|c|c|}
\hline Direção do carregamento & Distância mínima \\
\hline & $2,5 \mathrm{~d}$ \\
\hline $\begin{array}{c}\text { quando } \quad \mathrm{L}_{\mathrm{p}, \mathrm{s}} / \mathrm{d} \leq 2 \\
\text { quando } 2<\mathrm{L}_{\mathrm{p}, \mathrm{s}} / \mathrm{d}<6 \\
\text { quando } \mathrm{L}_{\mathrm{p}, \mathrm{s}} / \mathrm{d} \geq 6\end{array}$ & $\left(5 \mathrm{~L}_{\mathrm{p}, \mathrm{s}}+10 \mathrm{~d}\right) / 8$ \\
\hline & $5 d$ \\
\hline Paralelo às fibras & $1,5 \mathrm{~d}$ \\
\hline
\end{tabular}

Para carregamentos em ângulo, a área de cisalhamento deve ser equivalente à distância ao final da peça para uma conexão paralela. Caso use um fator redutor, a área de cisalhamento deve ser equivalente à metade da área anteriormente enunciada.

\subsection{3 - COMITÉ EUROPÉEN DE NORMALISATION (1993)}

$\mathrm{Na}$ norma da comunidade européia EUROCODE 5 - DESIGN OF TIMBER STRUCTURES do EUROPEAN PRESTANDARD (1993), encontram-se algumas informações sobre parafusos auto-atarraxantes solicitados axialmente. A resistência de projeto para estes parafusos é calculada pela fórmula:

$$
\mathrm{R}_{\mathrm{d}}=\mathrm{f}_{3, \mathrm{~d}} \cdot\left(\mathrm{L}_{\mathrm{R}}-\mathrm{d}\right)
$$

onde:

$\mathrm{R}_{\mathrm{d}}$ - Resistência de cálculo, em N;

$\mathrm{L}_{\mathrm{R}}$ - Comprimento de rosca inserida na peça principal de madeira, em mm;

d - Diâmetro do parafuso, em mm.

$$
\mathrm{f}_{3, \mathrm{~d}}=\frac{k_{\mathrm{mod}}}{\gamma_{m}} \cdot(1,5+0,6 \mathrm{~d}) \cdot \rho^{1 / 2}
$$

onde:

$\mathrm{f}_{3, \mathrm{~d}}$ - Parâmetro de tração de projeto;

$\mathrm{k}_{\text {mod }}$ - coeficiente de modificação;

$\gamma_{\mathrm{m}}$ - Coeficiente de ponderação das resistências dos materiais;

$\rho$ - Massa específica da madeira, em $\mathrm{kg} / \mathrm{m}^{3}$;

d - Diâmetro do parafuso, em mm. 
Esta equação somente é valida para as seguintes condições:

- Na região sem rosca do parafuso, a pré-furação da madeira deve ter o mesmo diâmetro do parafuso, enquanto que, na região com rosca, a pré-furação da madeira deve ser $70 \%$ do diâmetro do parafuso;

- O comprimento de penetração da rosca deve ser igual ou maior a 4 vezes o diâmetro do parafuso.

- A região sem rosca do parafuso deve ter o comprimento igual ou maior que a espessura do elemento principal da ligação.

Um detalhe construtivo importante é que as ligações estruturais devem ter pelo menos dois parafusos. Com relação aos espaçamentos mínimos, existem as seguintes recomendações para parafusos submetidos a esforços de cisalhamento:

- Entre parafusos, ao longo do comprimento da viga:

$$
4+3 \cdot \cos \alpha \cdot d
$$

- Entre parafusos, ao longo da largura da viga:

$$
3+\operatorname{sen} \alpha \cdot d
$$

- Entre o parafuso e a borda submetida à tração, ao longo do comprimento:

$$
7+5 \cdot \cos \alpha \cdot d
$$

- Entre o parafuso e a borda submetida à compressão, ao longo do comprimento: $7 d$

- Entre o parafuso e a borda submetida à compressão, na largura da viga:

$$
3+4 \cdot \operatorname{sen} \alpha \cdot d
$$

- Entre o parafuso e a borda submetida à compressão, na largura da viga:

$3 d$

\subsection{4 - CANADIAN STANDARD ASSOCIATION (1993)}

A norma canadense ENGINEERING DESIGN IN WOOD - SUPPLEMENT $N^{\mathrm{O}} 1$ 93 da CANADIAN STANDARS ASSOCIATION (1993) apresenta informações a respeito da utilização dos mais diversos tipos de conexões, incluindo-se os parafusos autoatarraxantes (lag screw). A resistência à tração axial do parafuso é calculada pela fórmula: 


$$
\mathrm{R}_{\mathrm{d}, 90}=\phi \cdot \mathrm{Y}_{\mathrm{w}} \cdot \mathrm{L}_{\mathrm{R}} \cdot \mathrm{n}_{\mathrm{p}}
$$

onde:

$\mathrm{R}_{\mathrm{d}, 90}$ - Resistência de cálculo na direção perpendicular às fibras, em N;

$\phi$ - 0,6 Coeficiente de minoração de resistência;

$\mathrm{Y}_{\mathrm{w}}=\mathrm{y}_{\mathrm{w}} \cdot\left(\mathrm{k}_{\mathrm{d}} \cdot \mathrm{k}_{\mathrm{sf}} \cdot \mathrm{k}_{\mathrm{T}}\right)$

$\mathrm{y}_{\mathrm{w}}$ - Resistência básica por milímetro de penetração de rosca - valor tabelado, em N/mm;

$\mathrm{k}_{\mathrm{D}}$ - Fator de duração de carregamento;

$\mathrm{k}_{\mathrm{SF}}$ - Fator de condições de utilização;

$\mathrm{k}_{\mathrm{T}}$ - Fator de tratamento;

$\mathrm{L}_{\mathrm{R}}$ - Comprimento de rosca inserida na peça principal de madeira, em mm;

$\mathrm{n}_{\mathrm{P}}$ - Número de parafusos.

Os valores da resistência básica à tração estão tabelados e apresentados em N por mm de rosca inserida na madeira, sendo que os valores dados são para os parafusos inseridos perpendiculares às fibras da madeira. Para resistência à tração com parafuso fixo paralelo às fibras, deve-se utilizar $75 \%$ do valor da resistência obtida com o parafuso fixo perpendicularmente. A tabela 2.6 apresenta os valores da resistência básica à tração.

Tabela 2.6 - Resistência básica à tração, $\mathrm{y}_{\mathrm{w}}(\mathrm{N} / \mathrm{mm})$

\begin{tabular}{|c|c|c|c|c|c|}
\hline Grupo de espécies & \multicolumn{5}{|c|}{ Diâmetro do parafuso } \\
\cline { 2 - 6 } & $1 / 4^{\prime \prime}$ & $5 / 16^{\prime \prime}$ & $3 / 8^{\prime \prime}$ & $7 / 16^{\prime \prime}$ & $1 / 2 "$ \\
$(6,35 \mathrm{~mm})$ & $(7,94 \mathrm{~mm})$ & $(9,53 \mathrm{~mm})$ & $(11,11 \mathrm{~mm})$ & $(12,70 \mathrm{~mm})$ \\
\hline D. Fir-Larch & 74 & 97 & 120 & 140 & 170 \\
\hline Hem-Fir & 37 & 55 & 70 & 86 & 100 \\
\hline Northen species & 27 & 42 & 58 & 70 & 84 \\
\hline
\end{tabular}

Com relação à pré-furação, adotam-se duas maneiras distintas. Na região sem rosca do parafuso, a pré-furação da madeira deve ter o mesmo diâmetro do parafuso enquanto que na região com rosca do parafuso, a pré-furação da madeira deve seguir as seguintes recomendações:

- Entre 0,65 a 0,85 do diâmetro do parafuso, ao utilizar madeiras de alta densidade,

- Entre 0,60 e 0,75 do diâmetro do parafuso, para madeiras de densidade intermediária,

- Entre 0,40 e 0,70 do diâmetro do parafuso, para madeiras de baixa densidade. 
Cabe ressaltar que os maiores valores da pré-furação são aplicados para parafuso com maior diâmetro.

A utilização de sabão ou outro lubrificante, não sendo à base de petróleo, é recomendada para facilitar a inserção do parafuso auto-atarraxante e prevenir danos no momento do atarraxamento.

O comprimento de penetração de rosca deve ser igual a 9 vezes o diâmetro do parafuso para madeiras de alta densidade e 11 vezes o diâmetro do parafuso para madeiras de baixa densidade. As recomendações acima citadas são para parafusos auto-atarraxantes que atendem à norma CSA Standard B34.

Com relação aos espaçamentos mínimos, existem as seguintes recomendações para parafusos submetidos a esforços de cisalhamento:

- Espaçamento entre parafusos em uma fileira:

Paralelo às fibras $\quad 4 \mathrm{~d}$

Perpendicular às fibras $\quad 3 \mathrm{~d}$

- Espaçamento entre fileiras:

Paralelo às fibras $\quad 2 \mathrm{~d}$

Perpendicular às fibras quando $\mathrm{e} / \mathrm{d} \leq 2 \quad 2,5 \mathrm{~d}$

quando $\quad \mathrm{e} / \mathrm{d} \geq 6 \quad 5 \mathrm{~d}$

- Espaçamento ao fim da peça:

Sofrendo tração $7 \mathrm{~d}$

Sofrendo compressão $\quad 5 \mathrm{~d}$ ou $50 \mathrm{~mm}$

- Espaçamento à borda lateral:

Paralelo às fibras $\quad 1,5 \mathrm{~d}$

Perpendicular às fibras $\quad 4 d$ com carregamento atuante

$1,5 \mathrm{~d}$ sem carregamento atuante

\subsection{5 - STANDARDS ASSOCIATION OF AUSTRÁLIA (1994)}

A norma australiana TIMBER STRUCTURES - PART 1: DESIGN METHODS da STANDARDS ASSOCIATION OF AUSTRÁLIA (1994) tem uma série de recomendações para a utilização de parafusos sextavados com rosca soberba axialmente carregados. Calcula-se a resistência à tração axial do parafuso utilizando-se a fórmula: 


$$
\mathrm{R}=\mathrm{k}_{13} \cdot \mathrm{f}
$$

onde:

$\mathrm{R}$ - Resistência à tração para um parafuso, em N;

$\mathrm{k}_{13}$ - Coeficiente que vale 1,0 para parafuso fixo perpendicular às fibras e 0,6 para parafuso fixo paralelo às fibras;

f - Capacidade característica de resistência do parafuso em $\mathrm{N}$ por mm de penetração (tabelado).

A partir da equação 14 , pode-se calcular a capacidade nominal $R_{n}$ para ligações que contenham n parafusos utilizando-se a fórmula:

$$
\mathrm{R}_{\mathrm{n}}=\mathrm{n}_{\mathrm{p}} \cdot \mathrm{R}
$$

onde:

$\mathrm{R}_{\mathrm{n}}$ - Resistência à tração para n parafusos, em N;

R - Resistência à tração para um parafuso, determinada pela equação 14;

$\mathrm{n}_{\mathrm{P}}$ - Número de parafusos.

A verificação da segurança, com base nos estados limites, é feita por meio do seguinte procedimento:

$$
\mathrm{R}_{\mathrm{d}}=\phi \mathrm{R} \geq \mathrm{F}_{\mathrm{d}}
$$

onde:

$\mathrm{R}_{\mathrm{d}}$ - Resistência de cálculo $=\phi \mathrm{R}$;

$\phi$ - Coeficiente de minoração de resistência $=0,8$;

$\mathrm{F}_{\mathrm{d}}$ - Força de tração de cálculo.

É recomendado que, na região sem rosca do parafuso, a pré-furação seja a mesma do diâmetro do parafuso e, para a região com rosca, a pré-furação seja a mesma do diâmetro do núcleo do parafuso.

Nesta norma são apresentadas duas tabelas para a resistência ao arrancamento do parafuso, uma para madeira com teor de umidade acima do ponto de saturação e outra para madeira seca ao ar. As tabelas 2.7 e 2.8 apresentam a resistência característica à tração para os parafusos inseridos perpendiculares às fibras da madeira. 
Tabela 2.7 - Resistência característica à tração, $(\mathrm{N} / \mathrm{mm})$ - Madeira com teor de umidade acima do ponto de saturação

\begin{tabular}{|c|c|c|c|c|c|}
\hline \multirow{2}{*}{ Grupos de espécies } & \multicolumn{5}{|c|}{ Diâmetro do parafuso em mm } \\
\cline { 2 - 6 } & 6 & 8 & 10 & 12 & 16 \\
\hline J1 & 149 & 168 & 189 & 208 & 241 \\
\hline J2 & 118 & 133 & 152 & 168 & 193 \\
\hline J3 & 83 & 98 & 112 & 124 & 143 \\
\hline J4 & 66 & 69 & 77 & 83 & 98 \\
\hline J5 & 50 & 58 & 58 & 68 & 77 \\
\hline J6 & 39 & 39 & 42 & 48 & 58 \\
\hline
\end{tabular}

Tabela 2.8 - Resistência característica à tração, $(\mathrm{N} / \mathrm{mm})$ - madeira seca ao ar

\begin{tabular}{|c|c|c|c|c|c|}
\hline \multirow{2}{*}{ Grupo de espécies } & \multicolumn{5}{|c|}{ Diâmetro do parafuso em mm } \\
\cline { 2 - 6 } & 6 & 8 & 10 & 12 & 16 \\
\hline JD1 & 185 & 210 & 232 & 261 & 301 \\
\hline JD2 & 147 & 166 & 191 & 210 & 241 \\
\hline JD3 & 104 & 122 & 141 & 154 & 179 \\
\hline JD4 & 83 & 87 & 97 & 104 & 124 \\
\hline JD5 & 62 & 66 & 73 & 85 & 97 \\
\hline JD6 & 48 & 48 & 54 & 60 & 73 \\
\hline
\end{tabular}

Para parafusos fixos paralelos às fibras, deve-se utilizar o correspondente a $60 \%$ dos valores tabelados para os parafusos fixos perpendiculares. Segundo esta norma as recomendações citadas são para parafusos auto-atarraxantes de aço carbono que atendam à norma AS 1476.

Com relação aos espaçamentos mínimos, existem as seguintes recomendações para parafusos submetidos a esforços de cisalhamento:

- Espaçamento entre parafusos:

$$
\text { Paralelo às fibras } \quad 10 \mathrm{~d}
$$

Perpendicular às fibras $3 \mathrm{~d}$

- Espaçamento da borda lateral: $\quad 5 d$

- Espaçamento do fim da peça: 3d 


\subsection{6 - ASSOCIAÇÃO BRASILEIRA DE NORMAS TÉCNICAS (1997)}

Um aspecto a considerar é a inexistência de critérios de dimensionamento para parafusos auto-atarraxantes submetidos a esforços de tração na norma NBR 7190 - "Projeto de Estruturas de Madeira”, ABNT (1997).

Mas pode-se utilizar como referência para o cálculo da resistência da ligação o que está enunciado no item sobre condições de segurança.

A segurança da estrutura em relação a possíveis estados limites será garantida por:

$$
\mathrm{S}_{\mathrm{d}} \leq \mathrm{R}_{\mathrm{d}}
$$

onde:

$\mathrm{S}_{\mathrm{d}}$ - é a solicitação de cálculo;

$\mathrm{R}_{\mathrm{d}}$ - é a resistência de cálculo.

Considera-se este caso especial, ao utilizar parafusos auto-atarraxantes submetidos a esforços axiais de tração, é possível tomar a resistência de cálculo $R_{\mathbb{d}}$ como fração da resistência característica $R_{k}$ estimada pela equação:

$$
\mathrm{R}_{\mathrm{d}}=\mathrm{k}_{\mathrm{mod}} \cdot \frac{R_{k}}{\gamma_{w}}
$$

onde:

$\mathrm{R}_{\mathrm{d}}$ - Resistência de cálculo;

$\mathrm{k}_{\text {mod }}$ - Coeficientes de modificação;

$\mathrm{R}_{\mathrm{k}}$ - Resistência característica;

$\gamma_{\mathrm{w}}$ - Coeficiente de minoração da resistência da madeira.

Os espaçamentos mínimos recomendados para pinos submetidos a esforços de cisalhamento são os seguintes:

- Entre o centro de dois pinos situados em uma mesma linha paralela à direção das fibras deve-se utilizar afastamentos de $6 \mathrm{~d}$ para pregos e $4 \mathrm{~d}$ para parafusos;

- Do centro do último pino à extremidade de peças tracionadas: 7d;

- Do centro do último pino à extremidade de peças comprimidas: 4d;

- Entre os centros de dois pinos situados em duas linhas paralelas à direção das fibras, medido perpendicularmente às fibras: $3 \mathrm{~d}$; 
- Do centro de qualquer pino à borda lateral da peça, medido perpendicularmente às fibras, quando o esforço transmitido for paralelo às fibras: $1,5 \mathrm{~d}$;

- Do centro de qualquer pino à borda lateral da peça, medido perpendicularmente às fibras, quando o esforço transmitido for normal às fibras, do lado onde atuam tensões de tração normal: $1,5 \mathrm{~d}$;

- Do centro de qualquer pino à borda lateral da peça, medido perpendicularmente às fibras, quando o esforço transmitido for normal às fibras, do lado onde atuam tensões de compressão normal: 4d.

\subsection{7 - FOREST PRODUCTS LABORATORY (1999)}

No WOOD HANDBOOK do FOREST PRODUCTS LABORATORY (1999), são apresentados definições e métodos de cálculos para os mais diversos tipos de ligações. Inclui-se nas ligações citadas os parafusos auto-atarraxantes, divididos em dois modelos: wood screw (parafusos de fenda para madeira) e lag screw (parafuso sextavado com rosca soberba).

\subsubsection{1 - Resistência à tração - Parafuso de fenda para madeira}

A resistência máxima do parafuso fixo na direção perpendicular às fibras da madeira, solicitado à tração, estando a madeira seca ao ar, pode ser calculada pelo método das tensões

admissíveis pela equação:

$$
R_{90}=108,25 \cdot \rho^{2} \cdot d \cdot L_{R}
$$

onde:

$\mathrm{R}_{90}$ - Resistência máxima de tração na direção perpendicular às fibras, em N;

$\rho$ - Massa específica da madeira a $12 \%$ de umidade, em $\mathrm{g} / \mathrm{mm}^{3}$;

d - Diâmetro do parafuso, em mm;

$\mathrm{L}_{\mathrm{R}}$ - Comprimento de rosca inserida na peça principal de madeira, em $\mathrm{mm}$.

O método das tensões admissíveis é a forma de cálculo adotada como padrão em ligações de estruturas de madeira pelo FOREST PRODUCTS LABORATORY (1999), sendo prevista como resistência admissível em uma ligação o correspondente a 1/6 do valor obtido pela equação 18 . 
Esta equação somente é valida para as seguintes condições:

- Para madeiras de baixa densidade, adota-se como pré-furação $70 \%$ do diâmetro do núcleo do parafuso;

- Para madeira de alta densidade, adota-se como pré-furação $90 \%$ do diâmetro do núcleo do parafuso.

- Para parafusos com comprimento entre 12,7 a 76,2 mm. Uma observação a ser feita é que para parafusos fora deste padrão, os resultados obtidos experimentalmente são menores que os estimados pela fórmula.

O valor da resistência para parafusos inseridos no sentido paralelo às fibras corresponde a 75\% do valor da resistência obtida com os parafusos fixos perpendiculares às fibras. Como pode ser observada na equação 18 , a resistência aumenta proporcionalmente ao quadrado da densidade da madeira.

Para o parafuso do modelo "tapping screw" (parafuso que possui rosca em todo seu comprimento) a força de tração é $10 \%$ maior do que as obtidas para parafusos do tipo wood screw mantendo o mesmo diâmetro e com o comprimento de rosca totalmente fixo no corpode-prova.

\subsubsection{2 - Resistência à tração - Parafuso auto-atarraxante}

A resistência máxima de tração para este tipo de parafusos auto-atarraxante, fixo perpendicular às fibras, em madeira seca ao ar, é calculada pelo método das tensões admissíveis pela equação:

$$
R_{90}=125,4 \cdot \rho^{3 / 2} \cdot d^{3 / 4} \cdot L_{R}
$$

onde:

$\mathrm{R}_{90}$ - Resistência máxima de tração na direção perpendicular às fibras, em N;

$\rho$ - Massa específica a $12 \%$ de umidade, em $\mathrm{g} / \mathrm{mm}^{3}$;

d - Diâmetro do parafuso, em mm;

$\mathrm{L}_{\mathrm{R}}$ - Comprimento de rosca inserida na peça principal de madeira, em $\mathrm{mm}$.

A resistência admissível da ligação corresponde a 1/5 do valor obtido pela equação 19. 
Esta equação somente é valida para as seguintes condições:

- Para madeiras de baixa densidade, a pré-furação deve ser entre 40 e $70 \%$ do diâmetro do parafuso;

- Para madeiras de alta densidade, a pré-furação deve ser entre 65 e $85 \%$ do diâmetro do parafuso, a menor porcentagem é aplicada para parafusos com menores diâmetros e a maior porcentagem é aplicada para maiores diâmetros de parafusos.

No caso de parafusos inseridos no sentido paralelo às fibras, adota-se o correspondente a $75 \%$ da resistência obtida com os parafusos fixos no sentido perpendicular às fibras.

Para que ocorra a máxima resistência admissível na ligação, deve-se introduzir na madeira um comprimento de rosca igual a 7 vezes o diâmetro do parafuso em madeiras de alta densidade, e entre 10 a 12 vezes o diâmetro do parafuso para madeiras de baixa densidade. Para comprimentos de rosca maiores que os especificados acima, estima-se que ocorrerá a ruptura do parafuso.

É recomendada a pré-furação para os dois modelos de parafusos, sendo fundamental fazer-se a lubrificação da superfície do parafuso, com o objetivo de facilitar a inserção do mesmo, especialmente no caso de madeira de alta densidade, independente do diâmetro e comprimento do parafuso auto-atarraxante a ser utilizado. Este procedimento não causa influência nos resultados da máxima resistência de tração obtida em ensaios experimentais.

Com relação aos espaçamentos, existem as seguintes recomendações para parafusos submetidos a esforços de cisalhamento:

- Espaçamento entre parafusos em uma fileira:

Paralelo às fibras $\quad 4 \mathrm{~d}$

- Espaçamento ao fim da peças:

Sofrendo tração $\quad 7 \mathrm{~d}$ para madeiras de baixa densidade

5d para madeiras de alta densidade

Sofrendo compressão $\quad 4 d$

- Espaçamento à borda lateral:

Paralelo às fibras $\quad 1,5 \mathrm{~d}$

Perpendicular às fibras $4 \mathrm{~d}$ com carregamento atuante

$1,5 \mathrm{~d}$ sem carregamento atuante 


\section{5 - CONCLUSÕES DA REVISÃO BIBLIOGRÁFICA}

O estudo de ligação com parafusos auto-atarraxantes solicitados por tração não é recente. Entretanto, as pesquisas realizadas utilizaram tipos específicos de parafusos autoatarraxantes. Para o parafuso do tipo torx auto-atarraxante, que é fabricado com aço temperado, as pesquisas são insuficientes para garantir informações adequadas e seguras para a utilização deste tipo parafuso em ligações de estruturas. Inclusive, nota-se que existem pesquisas sendo desenvolvidas sobre este assunto, cujos resultados foram apresentadas no simpósio de ligações em estruturas de madeira no 55 ${ }^{\text {th }}$ RILEM Annual Week de 12 a 14 de setembro de 2001. Dentre estes trabalhos constam os seguintes títulos: "Ligação em madeira com parafuso auto-atarraxante com rosca contínua", "Ligações com parafusos autoatarraxantes" e "Elementos de ligações com parafusos auto-atarraxantes internos".

Considerando o conteúdo dos mencionados artigos, pode-se concluir que o trabalho aqui proposto se constitui em mais uma contribuição cientifica com o objetivo de gerar informações que garantam a utilização destes parafusos com segurança nas estruturas de madeira.

De acordo com a bibliografia pesquisada, pode-se enumerar os seguintes fatores que influenciam na resistência das ligações constituídas por parafusos auto-atarraxantes: densidade e umidade da madeira, diâmetro do parafuso, comprimento de rosca inserida na madeira, pré-furação adotada, direção das fibras da madeira.

A densidade da madeira é muito importante em ligações que utilizem parafusos autoatarraxantes, pois quanto maior a densidade, maior a resistência obtida na ligação. Para a fixação dos parafusos em relação às fibras, muitas das referências bibliográficas consultadas indicam que a resistência à tração, utilizando-se parafusos auto-atarraxantes inseridos no sentido paralelo às fibras, é $75 \%$ da resistência obtida com os parafusos fixos perpendiculares às fibras. Na norma australiana TIMBER STRUCTURES - PART 1: DESIGN METHODS da STANDARDS ASSOCIATION OF AUSTRALIA (1994) recomenda-se para parafusos fixos paralelos às fibras que se utilize o correspondente a $60 \%$ dos valores da resistência tabelados para os parafusos fixos perpendiculares.

Analisado-se o que foi demonstrado em cada artigo ou norma, verifica-se para o parafuso auto-atarraxante, especificamente na região que possui rosca, que existe uma certa variação com relação ao diâmetro da pré-furação a ser adotada, mas os valores adotados nesta pré-furação estão situados em torno de $70 \%$ do diâmetro do parafuso. Uma 
observação importante é que o FOREST PRODUCTS LABORATORY (1999) possui um padrão diferente com relação à pré-furação entre os parafusos auto-atarraxantes e os parafusos de fenda para madeira. Para este último, a pré-furação leva em consideração aproximadamente $80 \%$ do diâmetro do núcleo do parafuso.

Um procedimento indicado para realizar a montagem das ligações é a lubrificação da superfície do parafuso. Isto tem por objetivo facilitar a inserção do parafuso, especialmente no caso de madeira de alta densidade, independente do diâmetro e comprimento do parafuso auto-atarraxante a ser utilizado. Este procedimento não tem influência nos resultados obtidos na resistência à tração, segundo BREYER, D. E. (1980). Outro cuidado necessário é atarraxar perfeitamente os parafusos, pois caso se faça de maneira errônea isto causará valores menores de resistência na ligação. 


\section{MATERIAS E MÉTODOS}

A seguir são apresentados os materiais utilizados neste trabalho, suas características e propriedades, bem como os métodos a serem utilizados nos ensaios, os equipamentos utilizados e a forma de obtenção dos dados.

\section{1 - MATERIAIS UTILIZADOS}

Utilizou-se parafuso torx auto-atarraxantes do modelo FB-SK-T30, produzido em aço temperado, fabricado pela empresa suíça SFS AG. Este parafuso possui as seguintes dimensões (diâmetro e comprimento): 7,5 X $132 \mathrm{~mm}$. Para este modelo de parafuso não estão disponíveis outras dimensões de diâmetros, mas temos uma grande variedade de comprimentos e sua cabeça possui fenda tipo "Torx" apropriada para utilização de parafusadeira. A figura 3.1 apresenta os parafusos especificados.

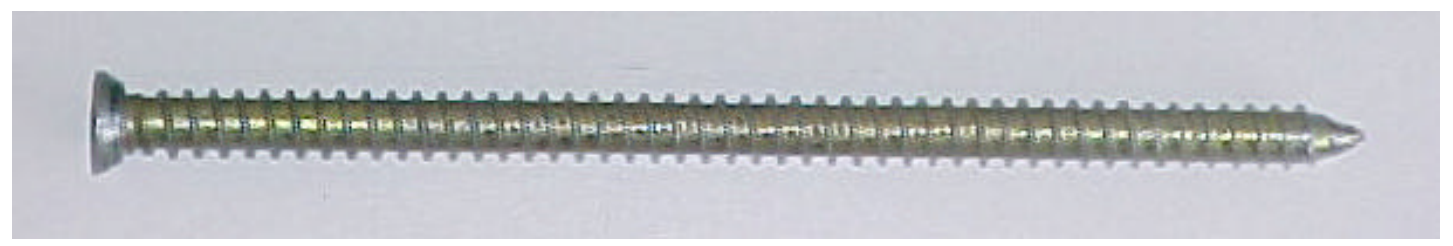

Figura 3.1 - Parafuso torx auto-atarraxantes modelo FB-SK-T30.

As espécies de madeiras utilizadas são: Pinus Taeda (Pinus taeda L), Eucalipto Grandis (Eucalyptus grandis) e Cupiúba (Goupia glabra). Estas espécies foram adotadas para se ter variação de densidade.

As peças de madeira utilizadas nos ensaios de ligações foram caracterizadas com o intuito de determinar as seguintes propriedades: resistência à compressão paralela às fibras, densidade e umidade. Estes ensaios de caracterização foram realizados de acordo com os procedimentos especificados pela norma "NBR 7190/97 - Projeto de Estruturas de Madeira". 


\section{2 - PROCEDIMENTOS UTILIZADOS NOS ENSAIOS DAS LIGAÇÕES}

Este projeto desenvolveu-se no Laboratório de Madeiras e de Estruturas de Madeira (LaMEM) do Departamento de Engenharia de Estruturas, da Escola de Engenharia de São Carlos (SET/EESC/USP).

Os ensaios foram realizados utilizando-se uma máquina universal "Amsler", com capacidade de $250 \mathrm{kN}$. A obtenção dos dados nos ensaios foi realizada por meio da leitura da força aplicada pela máquina universal.

\subsection{1 - Ensaios Realizados}

A espécie de madeira utilizada como base dos estudos é o Eucalipto Grandis, sendo as espécies do Pinus Taeda e Cupiúba utilizadas para comparação entre os resultados.

Os ensaios previstos estão divididos em três grupos denominados "ensaios preliminares", "ensaios principais" e "ensaios secundários".

\subsubsection{1- Ensaios preliminares}

Os ensaios preliminares têm por objetivo determinar o comprimento adequado de rosca a ser inserida na madeira para a realização dos ensaios principais e secundários, garantindo que a ruptura se dê na madeira, e verificar a influência da pré-furação na resistência da ligação. Também foram importantes no sentido de observar as dificuldades que poderiam ocorrer no processo de montagem dos corpos-de-prova e durante os testes.

Os resultados obtidos nestes ensaios preliminares permitiram a definição dos valores dos diâmetros de pré-furação e do comprimento de rosca inserida na madeira a serem utilizados nos ensaios principais e secundários.

Para determinar o comprimento de rosca adequado, preferiu-se utilizar para estes ensaios a espécie de maior densidade (Cupiúba). Adotou-se uma pré-furação de $5,5 \mathrm{~mm}$ e o comprimento de rosca variou de 80 a $120 \mathrm{~mm}$. Estes ensaios utilizaram madeira seca ao ar e a ligação era composta por um parafuso fixo na direção paralela às fibras.

Obtido o comprimento de rosca adequado igual a $80 \mathrm{~mm}$, realizaram-se ensaios para avaliar a variação de resistência da ligação ao variar a pré-furação e o comprimento de rosca inserida na madeira.

Para estes ensaios, adotaram-se os seguintes diâmetros para a pré-furação: 5,5 e 6 $\mathrm{mm}$ e o comprimento de rosca inserida na madeira de 60,70 e $80 \mathrm{~mm}$. 
Estes ensaios foram realizados utilizando madeira seca ao ar, das três espécies especificadas, utilizando-se um parafuso na direção paralela às fibras.

\subsubsection{2- Ensaios principais}

Os ensaios principais têm como objetivos a comparação do efeito de grupo (influência da quantidade de parafusos na resistência unitária) e a influência da variação da densidade da madeira (entre espécies diferentes).

Para quantificar o efeito de grupo, foram realizados ensaios em corpos-de-prova com grupos de 4, 8 e 16 parafusos, utilizando-se as três espécies especificadas.

Os ensaios principais foram realizados com os parafusos dispostos paralelos e perpendiculares às fibras, sendo utilizada madeira seca ao ar.

Os diâmetros de pré-furação adotados foram iguais a:

- 5,5 mm de diâmetro, para a espécie Pinus Taeda;

- 6,0 mm de diâmetro, para as espécies Eucalipto Grandis e Cupiúba.

Os comprimentos de rosca inserida na madeira adotados nestes ensaios foram iguais a:

- 80 mm, para a espécie Pinus Taeda;

- 70 mm, para as espécies Eucalipto Grandis e Cupiúba.

\subsubsection{3 - Ensaios secundários}

Estes ensaios têm como objetivo avaliar a influência de densidades diferentes em uma mesma espécie, a influência da umidade, e a influência do espaçamento entre parafusos na resistência.

Para avaliar a influência da densidade (na mesma espécie), foram utilizadas peças com maiores e menores densidades das espécies Eucalipto Grandis e Pinus Taeda.

Para avaliar a influência do teor de umidade, foram usadas peças de madeira, da espécie Eucalipto Grandis, nas seguintes condições de umidade: seca ao ar, com teor de umidade de $20 \%$, e saturada. Nestes dois casos de ensaios secundários, foram utilizados grupos de 4 parafusos, dispostos paralelamente e perpendicularmente à direção das fibras.

A avaliação da influência do espaçamento entre parafusos na resistência foi feita utilizando a espécie Pinus Taeda, com grupo de 4 parafusos dispostos na direção paralela às fibras. Foram utilizados os seguintes espaçamentos entre os parafusos: $15 \mathrm{~mm}, 30 \mathrm{~mm}$ e 45 $\mathrm{mm}$. 
Os diâmetros de pré-furação adotados foram iguais a:

- 5,5 mm de diâmetro, para a espécie Pinus Taeda;

- 6,0 mm de diâmetro, para as espécies Eucalipto Grandis e Cupiúba.

Os comprimentos de rosca inserida na madeira adotados nestes ensaios foram iguais a:

- 80 mm, para a espécie Pinus Taeda;

- 70 mm, para as espécies Eucalipto Grandis e Cupiúba.

\subsubsection{4 - Programa experimental realizado}

As tabelas 3.1 a 3.4 apresentam informações a respeito dos ensaios realizados, referentes à quantidade de corpos-de-prova ensaiados para cada espécie, teor de umidade, direção do esforço, espaçamento entre parafusos e observações pertinentes.

Tabela 3.1 - Ensaios realizados em corpos-de-prova com 1 parafuso (Ensaios preliminares)

\begin{tabular}{|c|c|c|c|c|c|c|}
\hline \multirow{2}{*}{$\begin{array}{l}\text { Teor de } \\
\text { umidade }\end{array}$} & \multirow{2}{*}{$\begin{array}{c}\text { Direção dos } \\
\text { esforços }\end{array}$} & \multirow{2}{*}{$\begin{array}{l}\text { Comprimento } \\
\text { de rosca } \\
\text { inserida na } \\
\text { madeira } \\
(\mathrm{mm})\end{array}$} & \multicolumn{3}{|c|}{ Número de corpos-de-prova } & \multirow[b]{2}{*}{ Observações } \\
\hline & & & $\begin{array}{l}\text { Pinus } \\
\text { Taeda }\end{array}$ & $\begin{array}{l}\text { Eucalipto } \\
\text { Grandis }\end{array}$ & Cupiúba & \\
\hline \multirow{4}{*}{$\begin{array}{c}\text { Entre } 12 \\
\text { e } 15 \%\end{array}$} & \multirow{4}{*}{ Paralela } & 80 a 120 & & & 5 & \multirow{4}{*}{$\begin{array}{c}\text { Pequena } \\
\text { variação de } \\
\text { umidade e } \\
\text { densidade. } \\
\text { Pré-furação } \\
\text { de } 5,5 \mathrm{~mm} .\end{array}$} \\
\hline & & 80 & 2 & 2 & 2 & \\
\hline & & 70 & 2 & 2 & 2 & \\
\hline & & 60 & 2 & 2 & 2 & \\
\hline \multirow{3}{*}{$\begin{array}{c}\text { Entre } 12 \\
\text { e } 15 \%\end{array}$} & \multirow{3}{*}{ Paralela } & 80 & 2 & 2 & 2 & \multirow{3}{*}{$\begin{array}{c}\text { Pequena } \\
\text { variação de } \\
\text { umidade e } \\
\text { densidade. } \\
\text { Pré-furação } \\
\text { de } 6,0 \text { mm. }\end{array}$} \\
\hline & & 70 & 2 & 2 & 2 & \\
\hline & & 60 & 2 & 2 & 2 & \\
\hline
\end{tabular}


Tabela 3.2 - Ensaios realizados em corpos-de-prova com 4 parafusos (Ensaios principais e secundários)

\begin{tabular}{|c|c|c|c|c|c|c|}
\hline \multirow{2}{*}{$\begin{array}{l}\text { Teor de } \\
\text { umidade }\end{array}$} & \multirow{2}{*}{$\begin{array}{c}\text { Espaçamentos } \\
\text { dos parafusos } \\
(\mathrm{mm})\end{array}$} & \multirow{2}{*}{$\begin{array}{c}\text { Direção dos } \\
\text { esforços }\end{array}$} & \multicolumn{3}{|c|}{ Número de corpos-de-prova } & \multirow[b]{2}{*}{ Observações } \\
\hline & & & $\begin{array}{l}\text { Pinus } \\
\text { Taeda }\end{array}$ & $\begin{array}{c}\text { Eucalipto } \\
\text { Grandis }\end{array}$ & Cupiúba & \\
\hline \multirow{2}{*}{$\begin{array}{c}\text { Entre } 12 \\
\text { e } 15 \%\end{array}$} & \multirow[t]{2}{*}{30} & Paralela & $5^{(1)}$ & $5^{(1)}$ & $5^{(1)}$ & \multirow{6}{*}{$\begin{array}{c}\text { Pequena } \\
\text { variação de } \\
\text { densidade }\end{array}$} \\
\hline & & Perpendicular & $5^{(1)}$ & $5^{(1)}$ & $5^{(1)}$ & \\
\hline \multirow[b]{2}{*}{$20 \%$} & \multirow[t]{2}{*}{30} & Paralela & & $5^{(2)}$ & & \\
\hline & & Perpendicular & & $5^{(2)}$ & & \\
\hline \multirow{2}{*}{\begin{tabular}{|l|} 
Ponto de \\
saturação
\end{tabular}} & \multirow[t]{2}{*}{30} & Paralela & & $5^{(2)}$ & & \\
\hline & & Perpendicular & & $5^{(2)}$ & & \\
\hline \multirow{2}{*}{$\begin{array}{l}\text { Entre } 12 \\
\text { e } 15 \%\end{array}$} & \multirow[t]{2}{*}{30} & Paralela & $5^{(2)}$ & $5^{(2)}$ & & \multirow{2}{*}{$\begin{array}{l}\text { Densidade } \\
\text { mínima }\end{array}$} \\
\hline & & Perpendicular & $5^{(2)}$ & $5^{(2)}$ & & \\
\hline \multirow{2}{*}{$\begin{array}{l}\text { Entre } 12 \\
\text { e } 15 \%\end{array}$} & \multirow[t]{2}{*}{30} & Paralela & $5^{(2)}$ & $5^{(2)}$ & & \multirow{2}{*}{$\begin{array}{c}\text { Densidade } \\
\text { máxima }\end{array}$} \\
\hline & & Perpendicular & $5^{(2)}$ & $5^{(2)}$ & & \\
\hline $\begin{array}{c}\text { Entre } 12 \\
\text { e } 15 \%\end{array}$ & 15 & Paralela & $5^{(2)}$ & & & $\begin{array}{l}\text { Variação de } \\
\text { espaçamento }\end{array}$ \\
\hline $\begin{array}{c}\text { Entre } 12 \\
\text { e } 15 \%\end{array}$ & 30 & Paralela & $5^{(2)}$ & & & $\begin{array}{l}\text { Variação de } \\
\text { espaçamento }\end{array}$ \\
\hline $\begin{array}{c}\text { Entre } 12 \\
\text { e } 15 \%\end{array}$ & 45 & Paralela & $5^{(2)}$ & & & $\begin{array}{l}\text { Variação de } \\
\text { espaçamento }\end{array}$ \\
\hline
\end{tabular}

Obs: (1) Ensaios Principais, (2) Ensaios secundários.

Tabela 3.3 - Ensaios realizados em corpos-de-prova com 8 parafusos (Ensaios principais)

\begin{tabular}{|c|c|c|c|c|c|c|}
\hline \multirow{2}{*}{$\begin{array}{l}\text { Teor de } \\
\text { umidade }\end{array}$} & \multirow{2}{*}{$\begin{array}{c}\text { Espaçamentos } \\
\text { dos parafusos } \\
(\mathrm{mm})\end{array}$} & \multirow{2}{*}{$\begin{array}{l}\text { Direção dos } \\
\text { Esforços }\end{array}$} & \multicolumn{3}{|c|}{ Número de corpos-de-prova } & \multirow[b]{2}{*}{ Observações } \\
\hline & & & $\begin{array}{l}\text { Pinus } \\
\text { Taeda }\end{array}$ & $\begin{array}{c}\text { Eucalipto } \\
\text { Grandis }\end{array}$ & Cupiúba & \\
\hline \multirow{2}{*}{$\begin{array}{c}\text { Entre } 12 \\
\text { e } 15 \%\end{array}$} & \multirow{2}{*}{30} & Paralela & 5 & 5 & 5 & \multirow{2}{*}{$\begin{array}{c}\text { Pequena } \\
\text { variação de } \\
\text { umidade e } \\
\text { densidade }\end{array}$} \\
\hline & & Perpendicular & 5 & 5 & 5 & \\
\hline
\end{tabular}

Tabela 3.4 - Ensaios realizados em corpos-de-prova com 16 parafusos (Ensaios principais)

\begin{tabular}{|c|c|c|c|c|c|c|}
\hline \multirow{2}{*}{$\begin{array}{l}\text { Teor de } \\
\text { umidade }\end{array}$} & \multirow{2}{*}{$\begin{array}{l}\text { Espaçamentos } \\
\text { dos parafusos } \\
\text { (mm) }\end{array}$} & \multirow{2}{*}{$\begin{array}{c}\text { Direção dos } \\
\text { esforços }\end{array}$} & \multicolumn{3}{|c|}{ Número de corpos-de-prova } & \multirow[b]{2}{*}{ Observações } \\
\hline & & & $\begin{array}{l}\text { Pinus } \\
\text { Taeda }\end{array}$ & $\begin{array}{l}\text { Eucalipto } \\
\text { Grandis }\end{array}$ & Cupiúba & \\
\hline $\begin{array}{c}\text { Entre } 12 \\
\text { e } 15 \%\end{array}$ & 30 & Paralela & 5 & 5 & 5 & $\begin{array}{c}\text { Pequena } \\
\text { variação de } \\
\text { umidade e } \\
\text { densidade }\end{array}$ \\
\hline
\end{tabular}

\subsection{2 - Extração dos Corpos-de-prova}

A madeira utilizada nos corpos-de-prova foi extraída aleatoriamente do lote. Para uma seqüência de ensaios, cada viga de madeira forneceu um corpo-de-prova para o ensaio 
de tração paralela e um corpo-de-prova para o ensaio de tração perpendicular às fibras.

Por exemplo, nos casos em que estavam previstos no programa experimental dos ensaios 5 corpos-de-prova para realização do ensaio de tração com 4 parafusos fixos paralelos às fibras utilizando uma determinada espécie de madeira. Era necessário utilizar 5 vigas para extração dos corpos-de-prova referentes ao lote de madeira em estudo. Esta madeira deveria apresentar teor de umidade entre 12 e $15 \%$.

Para os ensaios que exigiam um teor de umidade maior, em torno de $20 \%$ e no ponto de saturação, os corpos-de-prova foram imersos em um tanque de água, sendo a variação de umidade acompanhada por meio da utilização de peças testemunhas. Assim, o estudo da influência da variação dos fatores (teor de umidade e espaçamentos) foi feito em corpos-deprova extraídos das mesmas peças do exemplo anterior, buscando diminuir o efeito da variabilidade. Nos ensaios para verificar a influência da densidade em uma mesma espécie, obviamente, os corpos-de-prova foram extraídos de peças distintas. A figura 3.2 apresenta o esquema de extração dos corpos-de-prova de uma peça de madeira, extraída aleatoriamente do lote utilizado.
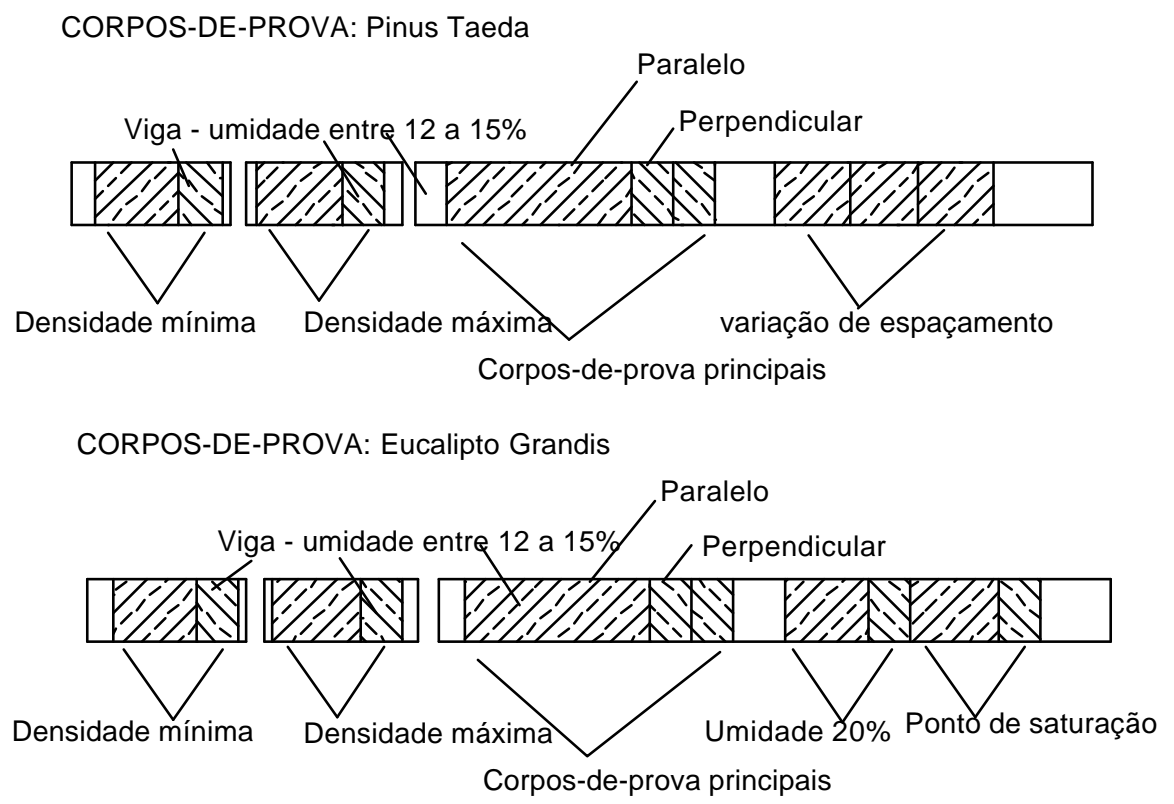

CORPOS-DE-PROVA: Cupiúba

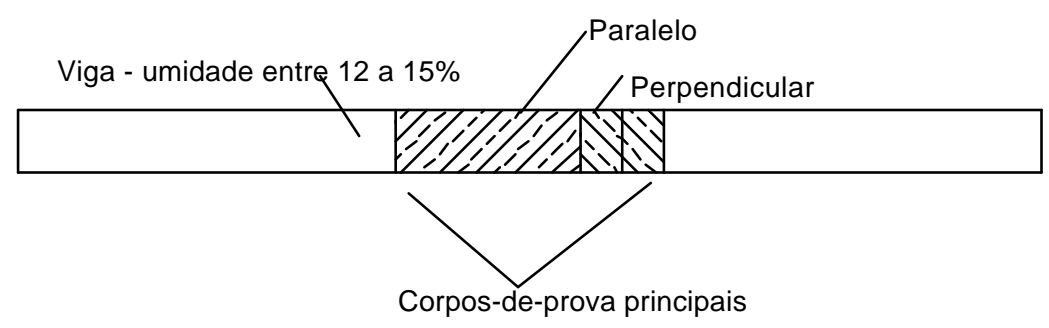

Figura 3.2 - Disposição dos corpos-de-prova para extração. 


\subsection{3 - Base de Fixação dos Parafusos}

A base de fixação do parafuso é um elemento de ligação entre os parafusos e a máquina universal de ensaios "Amsler". Este elemento de ligação é produzido com aço carbono SAE 1040.

Existem dois modelos de base de fixação: o primeiro consiste em um cilindro metálico para fixação de 1 parafuso e o outro é uma chapa metálica que possui um total de 16 furos para fixação dos parafusos, o que garante uma grande possibilidade de combinações no número e disposição dos parafusos a serem utilizados em ensaios de ligações. $\mathrm{O}$ espaçamento mínimo entre os parafusos corresponde a $15 \mathrm{~mm}$ entre eixos de simetria. Estes elementos de ligações podem ser observados na figura 3.3.

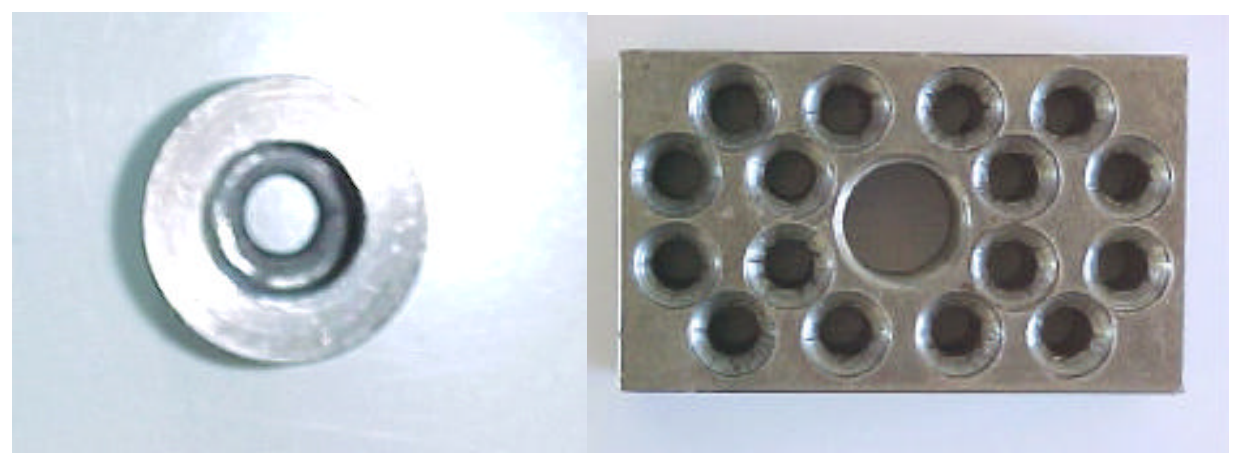

Figura 3.3 - Bases de fixação.

\subsection{4 - Dimensões e Montagem dos Corpos-de-prova}

Para os ensaios preliminares, os corpos-de-prova com 1 parafuso submetido à tração paralela às fibras possuem dimensões nominais de 5 x $15 \times 30 \mathrm{~cm}$, como apresentado na figura 3.4.

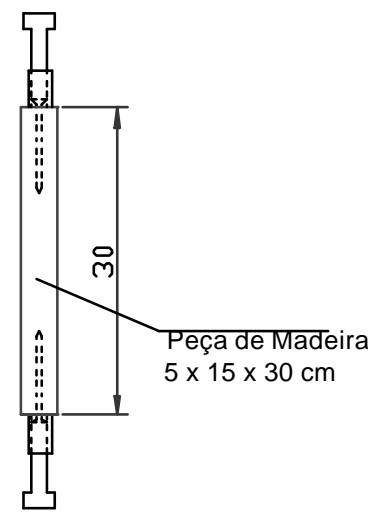

Figura 3.4 - Dimensões dos corpos-de-prova nos ensaios preliminares. 
Para os ensaios principais, os corpos-de-prova com os parafusos submetidos à tração paralela às fibras possuem dimensões nominais de $6 \times 15 \times 45 \mathrm{~cm}$, possibilitando realizar três ensaios com a mesma peça, como se pode verificar na figura 3.5, analisando a variação da resistência do grupo de parafusos. Isto proporciona uma diminuição da variabilidade entre os corpos-de-prova e otimiza o processo de montagem dos corpos-de-prova.

Para os ensaios secundários, os corpos-de-prova submetidos à tração paralela às fibras possuem dimensões nominais de 6 x 15 x $20 \mathrm{~cm}$. A montagem do corpo-de-prova é semelhante aos dos ensaios principais mas somente utilizam-se 4 parafusos em cada extremidade sendo realizado um ensaio por peça.

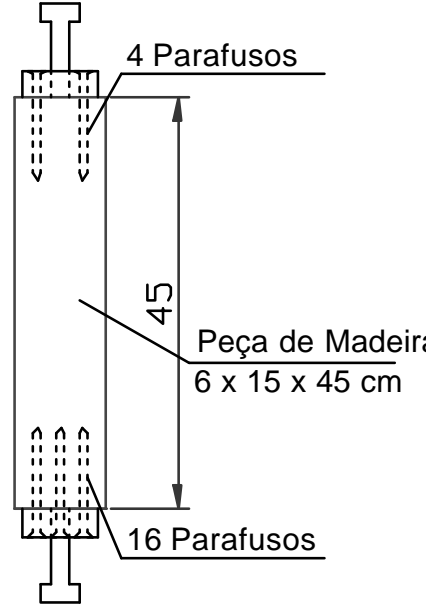

Etapa 1
Pinus Taeda

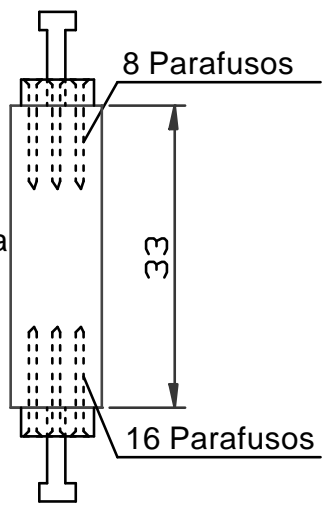

Etapa 2

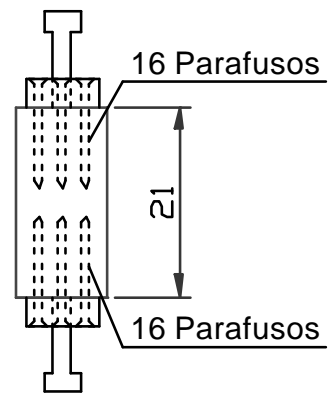

Etapa 3

Figura 3.5 - Dimensões dos corpos-de-prova com os parafusos dispostos paralelamente às fibras.

Por outro lado, corpos-de-prova com os parafusos submetidos à tração perpendicular às fibras, embora apresentem montagem semelhante ao do corpo-de-prova submetido à tração paralela, possuem as dimensões nominais de $6 \times 10 \times 30 \mathrm{~cm}$, como se pode verificar na figura 3.6. 


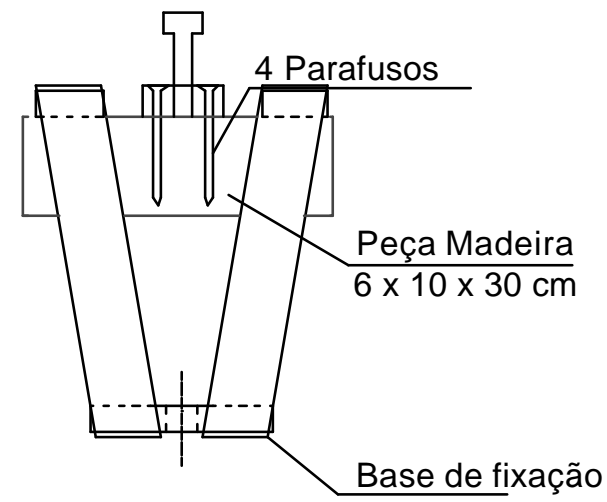

Figura 3.6 - Dimensões dos corpos-de-prova com os parafusos dispostos perpendicularmente às fibras.

Após o corte do corpo-de-prova nas dimensões especificadas, realizou-se a préfuração. Posteriormente, foi feita a fixação dos parafusos utilizando-se as bases de fixação e uma peça de madeira entre a base e o corpo-de-prova, que tem a finalidade de manter a profundidade de rosca especificada. Este procedimento é para garantir que ocorra a ruptura da ligação e não, do parafuso.

Inicialmente, foi utilizada uma furadeira da marca METABO, modelo BE $622 \mathrm{~S}$ $\mathrm{R}+\mathrm{L}$, que possui $35 \mathrm{Nm}$ de torque fixo. Mas, devido ao grande torque, se mostrou inadequada, pois freqüentemente ocorria a quebra da ferramenta torx ou da cabeça do parafuso, quando se terminava de parafusar.

Posteriormente, foi utilizada uma parafusadeira da marca DeWalt, modelo Dw268K, que possui controle de torque regulável na faixa entre 4 e $26 \mathrm{Nm}$ e velocidade variável. Este equipamento se mostrou adequado para este tipo de operação, pois mantém em perfeitas condições os parafusos e a ferramenta torx.

\subsection{5 - Arranjo dos Ensaios}

Com o corpo-de-prova previamente montado, foi feita sua fixação na máquina universal. As folgas presentes no sistema são eliminadas através de uma manivela de ajuste localizada na base fixa.

Após estes procedimentos, iniciava-se a sequiência de carregamento da ligação. A figura 3.7 e 3.8 apresenta o esquema dos ensaios para os parafusos dispostos paralelamente e perpendicularmente às fibras. 


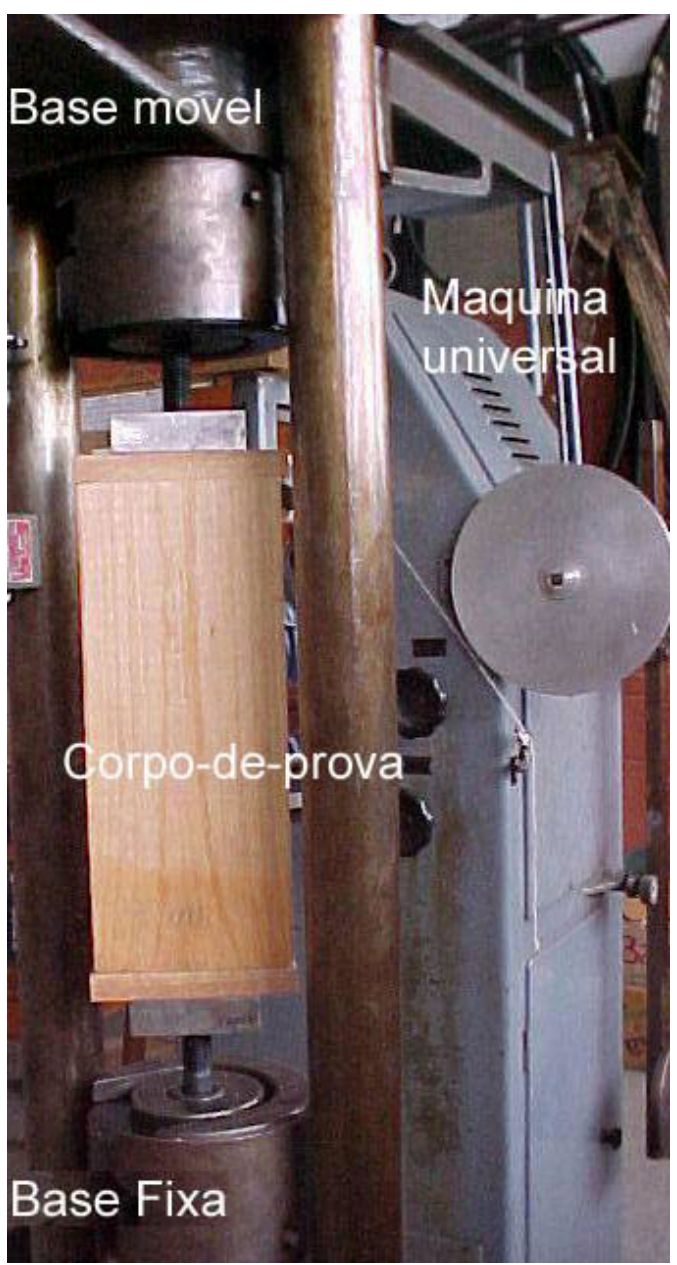

Figura 3.7 - Ensaio para parafusos na direção paralela às fibras.

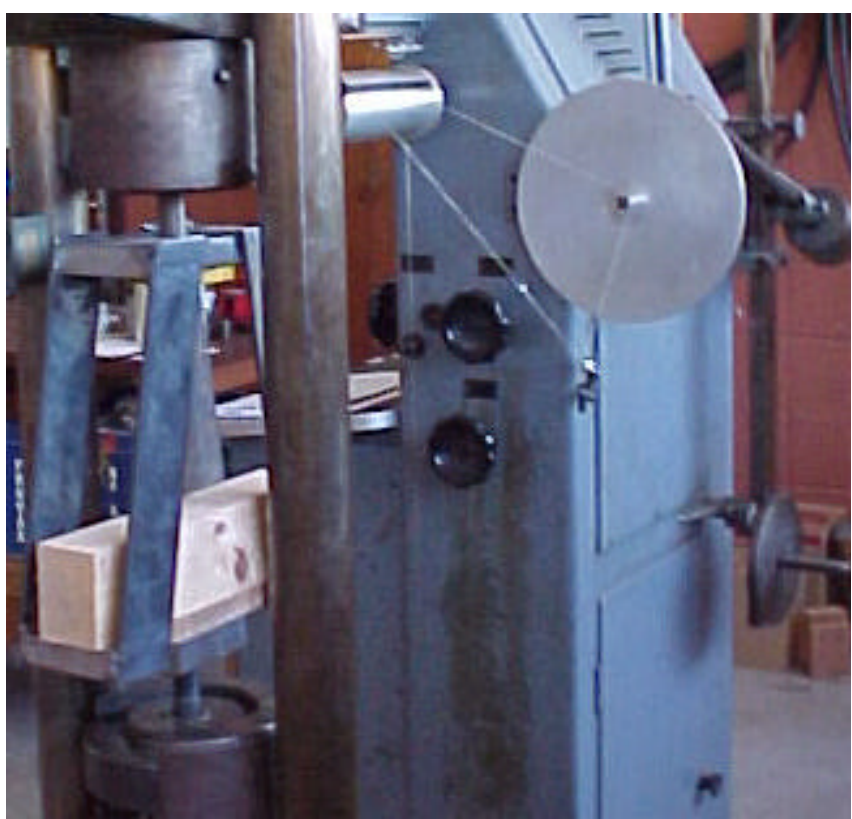

Figura 3.8 - Ensaio para parafusos na direção perpendicular às fibras. 


\subsection{6- Forma de Aplicação do Carregamento}

Os ensaios foram realizados utilizando-se uma máquina universal da marca Amsler, com capacidade de $250 \mathrm{kN}$.

Para cada tipo de ensaio previsto na programação experimental, foi realizado um ensaio adicional para determinar qual seria a resistência da ligação. Estes ensaios foram realizados de forma que o carregamento foi aplicado de maneira contínua, ou seja, sem realizar os ciclos de carregamentos previstos no anexo C da norma brasileira "NBR 7190 Projeto de Estruturas de Madeira".

Assim, após obter a força de ruptura por meio do ensaio adicional. Dava-se início aos respectivos ensaios previstos na programação experimental. Estes ensaios foram realizados aplicando-se o carregamento de forma contínua de maneira a obter a ruptura da ligação em um tempo aproximado entre 5 a 8 minutos. 


\section{RESULTADOS OBTIDOS}

A seguir são apresentados os resultados experimentais obtidos. Por meio da força de ruptura da ligação, será obtido o valor da "resistência". O termo "resistência" será utilizado como sendo a resistência à tração em Newton por milímetro do comprimento de rosca efetivo.

O comprimento de rosca efetivo $\left(\mathrm{L}_{\mathrm{RE}}\right)$ é obtido através da subtração da dimensão da ponta do parafuso, que tem como medida o próprio diâmetro do parafuso, do comprimento rosca inserida $\left(\mathrm{L}_{\mathrm{R}}\right)$, como mostrado na figura 4.1.

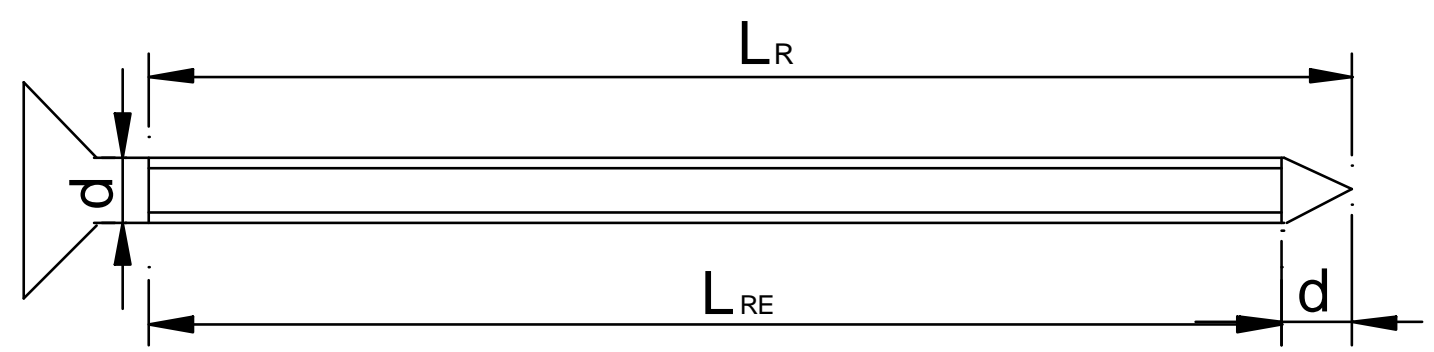

Figura 4.1 - Representação dos comprimentos de rosca.

Portanto, os comprimentos de rosca efetivos são:

- $\mathrm{L}_{\mathrm{RE}}=72,5 \mathrm{~mm}$, para o caso de $\mathrm{L}_{\mathrm{R}}=80 \mathrm{~mm}$;

- $\mathrm{L}_{\mathrm{RE}}=62,5 \mathrm{~mm}$, para o caso de $\mathrm{L}_{\mathrm{R}}=70 \mathrm{~mm}$;

- $\mathrm{L}_{\mathrm{RE}}=52,5 \mathrm{~mm}$, para o caso de $\mathrm{L}_{\mathrm{R}}=60 \mathrm{~mm}$.

Utilizando-se os valores da "resistência", foram feitas as análises das principais variáveis que influenciam na resistência da ligação. 


\section{1 - ENSAIOS PRELIMINARES}

Os ensaios preliminares tiveram como objetivo avaliar o comprimento adequado de rosca inserida na madeira para realização dos ensaios principais, e verificar a influência da pré-furação e do comprimento de rosca inserida na madeira na resistência da ligação.

A tabela 4.1 apresenta os resultados obtidos inicialmente para a espécie Cupiúba. A pré-furação nestes ensaios foi igual a $5,5 \mathrm{~mm}$.

Tabela 4.1 - Resistência e modo de ruptura da ligação em relação ao comprimento de rosca inserida na madeira - Espécie Cupiúba

\begin{tabular}{|c|c|c|c|}
\hline $\begin{array}{c}\text { Corpo-de- } \\
\text { prova }\end{array}$ & $\begin{array}{c}\text { Comprimento de } \\
\text { rosca (mm) }\end{array}$ & Força de ruptura (kN) & Modo de ruptura \\
\hline $\mathrm{Cp}-1$ & 120 & 19,30 & Ruptura do parafuso \\
\hline $\mathrm{Cp}-2$ & 120 & 17,75 & Ruptura do parafuso \\
\hline $\mathrm{Cp}-3$ & 90 & 18,10 & Ruptura do parafuso \\
\hline $\mathrm{Cp}-4$ & 80 & 15,90 & Ruptura da ligação \\
\hline $\mathrm{Cp}-5$ & 80 & 16,55 & Ruptura da ligação \\
\hline
\end{tabular}

Estes resultados indicam o valor máximo de $80 \mathrm{~mm}$, de forma a garantir que não ocorra a ruptura no parafuso. A seguir foram testados corpos-de-prova das três espécies em estudo, variando o diâmetro da pré-furação $(5,5$ e 6,0 mm) e o comprimento de rosca inserida $(60,70$ e $80 \mathrm{~mm})$. A tabela 4.2 apresenta os valores das propriedades das madeiras utilizadas nos corpos-de-prova.

Tabela 4.2 - Propriedades da madeira - Ensaios preliminares

\begin{tabular}{|c|c|c|c|c|}
\hline $\begin{array}{c}\text { Espécie de } \\
\text { madeira }\end{array}$ & Corpo-de-prova & $\begin{array}{c}\text { Massa } \\
\text { específica } \\
\left(\mathbf{g} / \mathbf{c m}^{\mathbf{3}}\right)\end{array}$ & $\begin{array}{c}\text { Teor de } \\
\text { umidade em \% }\end{array}$ & $\begin{array}{c}\mathbf{f}_{\mathbf{c}, \mathbf{0}} \\
(\mathbf{M P a})\end{array}$ \\
\hline Pinus Taeda & Pf-1 & 0,44 & 14,0 & 37,5 \\
& Pf-2 & 0,41 & 11,9 & 42,4 \\
\hline Eucalipto & Ef-1 & 0,66 & 13,5 & 49,6 \\
Grandis & Ef-2 & 0,77 & 13,6 & 63,4 \\
\hline Cupiúba & Cf-1 & 0,80 & 11,6 & 55,2 \\
& Cf-2 & 0,78 & 11,8 & 61,1 \\
\hline
\end{tabular}

As tabelas 4.3 e 4.4 apresentam os resultados da resistência da ligação para a préfuração, igual $6,0 \mathrm{~mm}$ e 5,5 mm, respectivamente. 
Tabela 4.3 - Determinação da variação de resistência da ligação - Pré-furação 6,0 mm

\begin{tabular}{|c|c|c|c|c|}
\hline $\begin{array}{c}\text { Espécie de } \\
\text { madeira } \\
\end{array}$ & $\begin{array}{c}\mathrm{N}^{0} \text {. do corpo } \\
\text { de prova }\end{array}$ & $\begin{array}{c}\text { Comprimento de } \\
\text { rosca }(\mathrm{mm})\end{array}$ & $\begin{array}{c}\text { Força de } \\
\text { ruptura }(\mathbf{k N})\end{array}$ & $\begin{array}{c}\text { Resistência } \\
(\mathrm{N} / \mathrm{mm})\end{array}$ \\
\hline \multirow{6}{*}{ Pinus Taeda } & Pf-1 & 80 & 11,60 & 160 \\
\hline & Pf-2 & 80 & 11,25 & 155 \\
\hline & Pf-1 & 70 & 9,10 & 146 \\
\hline & Pf-2 & 70 & 9,40 & 150 \\
\hline & Pf-1 & 60 & 8,50 & 162 \\
\hline & Pf-2 & 60 & 7,80 & 149 \\
\hline \multirow{6}{*}{$\begin{array}{l}\text { Eucalipto } \\
\text { Grandis }\end{array}$} & Ef-1 & 80 & 13,40 & 185 \\
\hline & Ef-2 & 80 & 16,70 & 230 \\
\hline & Ef-1 & 70 & 13,80 & 220 \\
\hline & Ef-2 & 70 & 15,00 & 240 \\
\hline & Ef-1 & 60 & - & - \\
\hline & Ef-2 & 60 & 14,15 & 269 \\
\hline \multirow{6}{*}{ Cupiúba } & $\overline{C f-1}$ & 80 & 15,70 & 217 \\
\hline & Cf-2 & 80 & 16,50 & 228 \\
\hline & $\mathrm{Cf}-1$ & 70 & 12,80 & 205 \\
\hline & $\mathrm{Cf}-2$ & 70 & 14,00 & 224 \\
\hline & Cf-1 & 60 & 11,50 & 219 \\
\hline & $\mathrm{Cf}-2$ & 60 & 12,30 & 234 \\
\hline
\end{tabular}

Tabela 4.4 - Determinação da variação de resistência da ligação - Pré-furação 5,5 mm

\begin{tabular}{|c|c|c|c|c|}
\hline $\begin{array}{l}\text { Espécie de } \\
\text { madeira }\end{array}$ & $\begin{array}{c}\mathrm{N}^{\mathbf{0}} \text {. do corpo } \\
\text { de prova }\end{array}$ & $\begin{array}{l}\text { Comprimento de } \\
\text { rosca }(\mathrm{mm})\end{array}$ & $\begin{array}{c}\text { Força de } \\
\text { ruptura }(\mathbf{k N})\end{array}$ & $\begin{array}{c}\text { Resistência } \\
(\mathbf{N} / \mathbf{m m})\end{array}$ \\
\hline \multirow{6}{*}{ Pinus Taeda } & Pf-1 & 80 & 12,85 & 177 \\
\hline & Pf-2 & 80 & 13,10 & 181 \\
\hline & Pf-1 & 70 & 9,95 & 158 \\
\hline & Pf-2 & 70 & 10,90 & 174 \\
\hline & Pf-1 & 60 & 8,65 & 165 \\
\hline & Pf-2 & 60 & 8,90 & 170 \\
\hline \multirow{6}{*}{$\begin{array}{l}\text { Eucalipto } \\
\text { Grandis }\end{array}$} & Ef-1 & 80 & 16,80 & 232 \\
\hline & Ef-2 & 80 & 17,20 & 237 \\
\hline & Ef-1 & 70 & 15,70 & 251 \\
\hline & Ef-2 & 70 & 16,70 & 267 \\
\hline & Ef-1 & 60 & - & - \\
\hline & Ef-2 & 60 & 15,95 & 303 \\
\hline \multirow{6}{*}{ Cupiúba } & Cf-1 & 80 & 17,30 & 239 \\
\hline & Cf-2 & 80 & 17,50 & 241 \\
\hline & Cf-1 & 70 & 13,80 & 221 \\
\hline & Cf-2 & 70 & 16,50 & 264 \\
\hline & Cf-1 & 60 & 13,40 & 255 \\
\hline & Cf-2 & 60 & 15,70 & 299 \\
\hline
\end{tabular}




\section{2 - ENSAIOS PRINCIPAIS}

Antes da apresentação dos resultados obtidos é necessário fazer um comentário a respeito das formas de ruptura observadas nos ensaios.

Para os parafusos dispostos paralelos às fibras, a ruptura foi caracterizada pelo cisalhamento da madeira em torno da rosca do parafuso, ocasionando seu deslizamento em relação ao corpo-de-prova, indicando a perda de capacidade resistente da ligação.

Para os parafusos dispostos perpendiculares às fibras, na maioria dos casos a ruptura não foi caracterizada pelo cisalhamento da madeira em torno da rosca do parafuso, mas sim pela ruptura do corpo-de-prova. Foram realizados diversos esquemas de montagem de corpos-de-prova, com o objetivo de obter o modo de ruptura por cisalhamento da madeira em torno da rosca utilizando grupos de parafusos fixos perpendiculares às fibras, mas não se obteve sucesso. Portanto, para estes ensaios não é possível fazer uma análise mais detalhada dos seus resultados, pois não ocorreu o modo de ruptura desejado. As figuras 4.2 e 4.3 apresentam os modos de ruptura observados.

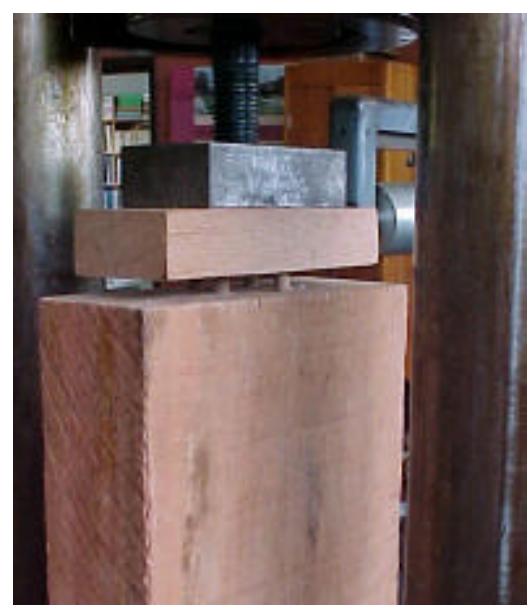

Figura 4.2 - Forma de ruptura para parafusos paralelos às fibras - deslizamento do parafuso.

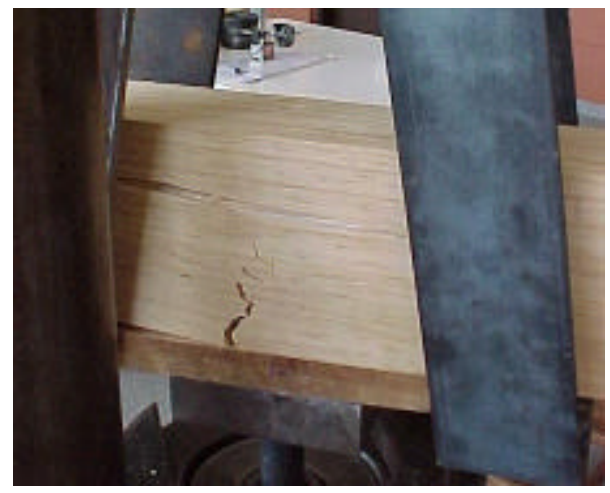

Figura 4.3 - Forma de ruptura para parafusos perpendiculares às fibras 


\subsection{1 - Pinus Taeda}

As tabelas 4.5 a 4.9 apresentam os resultados obtidos para a espécie Pinus Taeda. Nestes ensaios, a pré-furação é igual a 5,5 mm e o comprimento de rosca inserida é igual a $80 \mathrm{~mm}$.

Tabela 4.5 - Ensaios com 4 parafusos paralelos às fibras - Pinus Taeda

\begin{tabular}{|c|c|c|c|c|c|}
\hline \multirow{2}{*}{$\begin{array}{c}\mathrm{N}^{\mathrm{o}} \text { - do } \\
\text { corpo de } \\
\text { prova }\end{array}$} & \multicolumn{2}{|c|}{ Características do corpo-de-prova } & \multirow{2}{*}{$\begin{array}{c}\text { Força de } \\
\text { ruptura } \\
\left(\mathrm{g} / \mathrm{cm}^{3}\right)\end{array}$} & $\begin{array}{c}\text { Massa específica } \\
\text { em } \%\end{array}$ & $\begin{array}{c}\text { Teor de umidade } \\
(\mathrm{N} / \mathrm{mm})\end{array}$ \\
\hline $\mathrm{P}-1$ & 0,45 & 9,4 & 48,2 & 45,10 & 156 \\
\hline P-2 & 0,45 & 11,8 & 52,3 & 50,50 & 174 \\
\hline P-3 & 0,43 & 11,5 & 52,6 & 47,00 & 162 \\
\hline P-4 & 0,45 & 9,5 & 53,1 & 47,50 & 164 \\
\hline P-5 & 0,45 & 10,2 & 45,1 & 49,20 & 170 \\
\hline
\end{tabular}

Tabela 4.6 - Ensaios com 8 parafusos paralelos às fibras - Pinus Taeda

\begin{tabular}{|c|c|c|c|c|c|}
\hline \multirow{2}{*}{$\begin{array}{c}\mathrm{N}^{\mathrm{O}} \text {. do } \\
\text { corpo de } \\
\text { prova }\end{array}$} & \multicolumn{3}{|c|}{ Características do corpo-de-prova } & \multirow{2}{*}{$\begin{array}{c}\text { Força de } \\
\text { ruptura } \\
(\mathrm{kN})\end{array}$} & \multirow{2}{*}{$\begin{array}{c}\text { Resistência } \\
\text { (N/mm) }\end{array}$} \\
\hline & $\begin{array}{c}\text { Massa específica } \\
\left(\mathrm{g} / \mathrm{cm}^{3}\right)\end{array}$ & $\begin{array}{c}\text { Teor de umidade } \\
\text { em } \%\end{array}$ & $\begin{array}{c}\mathrm{f}_{\mathrm{c}, 0} \\
(\mathrm{MPa})\end{array}$ & & \\
\hline P-6 & 0,48 & 9,1 & 55,6 & 76,70 & 132 \\
\hline P-7 & 0,49 & 10,4 & 51,7 & 96,00 & 166 \\
\hline P-8 & 0,45 & 10,2 & 52,7 & 77,00 & 133 \\
\hline P-9 & 0,45 & 9,5 & 55,9 & 89,40 & 154 \\
\hline P-10 & 0,45 & 8,8 & 48,9 & 83,40 & 146 \\
\hline
\end{tabular}


Tabela 4.7 - Ensaios com 16 parafusos paralelos às fibras - Pinus Taeda

\begin{tabular}{|c|c|c|c|c|c|}
\hline \multirow{2}{*}{$\begin{array}{c}\mathrm{N}^{\mathrm{o}} \text { - do } \\
\text { corpo de } \\
\text { prova }\end{array}$} & \multicolumn{3}{|c|}{ Características do corpo-de-prova } & \multirow{2}{*}{$\begin{array}{c}\text { Força de } \\
\text { ruptura } \\
(\mathrm{kN})\end{array}$} & \multirow{2}{*}{$\begin{array}{c}\text { Resistência } \\
\text { (N/mm) }\end{array}$} \\
\hline & $\begin{array}{c}\text { Massa específica } \\
\left(\mathrm{g} / \mathrm{cm}^{3}\right)\end{array}$ & $\begin{array}{c}\text { Teor de umidade } \\
\text { em } \%\end{array}$ & $\begin{array}{c}\mathrm{f}_{\mathrm{c}, 0} \\
(\mathrm{MPa})\end{array}$ & & \\
\hline $\mathrm{P}-11$ & 0,40 & 9,2 & 53,9 & 139,00 & 120 \\
\hline $\mathrm{P}-12$ & 0,50 & 9,0 & 57,4 & 159,00 & 137 \\
\hline $\mathrm{P}-13$ & 0,46 & 8,3 & 51,9 & 151,00 & 130 \\
\hline $\mathrm{P}-14$ & 0,45 & 8,5 & 43,5 & 127,50 & 110 \\
\hline $\mathrm{P}-15$ & 0,46 & 8,5 & 53,8 & 157,50 & 136 \\
\hline
\end{tabular}

Tabela 4.8 - Ensaios com 4 parafusos perpendiculares às fibras - Pinus Taeda

\begin{tabular}{|c|c|c|c|c|c|}
\hline \multirow{2}{*}{$\begin{array}{c}\mathrm{N}^{0} \text { - do } \\
\text { corpo de } \\
\text { prova }\end{array}$} & \multicolumn{2}{|c|}{ Características do corpo-de-prova } & $\begin{array}{c}\text { Força de } \\
\text { ruptura } \\
\left(\mathrm{g} / \mathrm{cm}^{3}\right)\end{array}$ & $\begin{array}{c}\text { Resistência } \\
(\mathrm{N} / \mathrm{mm})\end{array}$ & \\
\hline P-16 & 0,48 & 12,5 & 42,2 & 52,20 & 180 \\
\hline P-17 & 0,50 & 13,8 & 47,9 & 57,00 & 197 \\
\hline P-18 & 0,49 & 12,5 & 55,0 & 45,50 & 157 \\
\hline P-19 & 0,48 & 12,9 & 42,8 & 47,50 & 164 \\
\hline P-20 & 0,42 & 14,0 & 39,5 & 49,50 & 171 \\
\hline
\end{tabular}

Tabela 4.9 - Ensaios com 8 parafusos perpendiculares às fibras - Pinus Taeda

\begin{tabular}{|c|c|c|c|c|c|}
\hline \multirow{2}{*}{$\begin{array}{c}\mathrm{N}^{\mathrm{O}} \text { - do } \\
\text { corpo de } \\
\text { prova }\end{array}$} & \multicolumn{3}{|c|}{ Características do corpo-de-prova } & \multirow{2}{*}{$\begin{array}{c}\text { Força de } \\
\text { ruptura } \\
(\mathrm{kN})\end{array}$} & \multirow{2}{*}{$\begin{array}{c}\text { Resistência } \\
\text { (N/mm) }\end{array}$} \\
\hline & $\begin{array}{c}\text { Massa específica } \\
\left(\mathrm{g} / \mathrm{cm}^{3}\right)\end{array}$ & $\begin{array}{c}\text { Teor de umidade } \\
\text { em } \%\end{array}$ & $\begin{array}{c}\mathrm{f}_{\mathrm{c}, 0} \\
(\mathrm{MPa})\end{array}$ & & \\
\hline $\mathrm{P}-21$ & 0,44 & 13,0 & 48,0 & 66,00 & 114 \\
\hline P-22 & 0,57 & 12,3 & 45,9 & 76,60 & 132 \\
\hline P-23 & 0,49 & 12,5 & 55,0 & 68,70 & 118 \\
\hline P-24 & 0,47 & 13,2 & 34,1 & 57,30 & 99 \\
\hline $\mathrm{P}-25$ & 0,42 & 13,5 & 38,8 & 47,50 & 82 \\
\hline
\end{tabular}




\subsection{2 - Eucalipto Grandis}

As tabelas 4.10 a 4.14 apresentam os resultados obtidos para a espécie Eucalipto Grandis. Nestes ensaios, a pré-furação é igual a 6,0 mm e o comprimento de rosca inserida é igual a $70 \mathrm{~mm}$.

Tabela 4.10 - Ensaios com 4 parafusos paralelos às fibras - Eucalipto Grandis

\begin{tabular}{|c|c|c|c|c|c|}
\hline \multirow{2}{*}{$\begin{array}{c}\mathrm{N}^{\mathrm{o}} \text { - do } \\
\text { corpo de } \\
\text { prova }\end{array}$} & \multicolumn{2}{|c|}{ Características do corpo-de-prova } & \multirow{2}{*}{$\begin{array}{c}\text { Força de } \\
\text { ruptura } \\
\left(\mathrm{g} / \mathrm{cm}^{3}\right)\end{array}$} & $\begin{array}{c}\text { Massa específica } \\
\text { em } \%\end{array}$ & $\begin{array}{c}\text { Teor de umidade } \\
(\mathrm{N} / \mathrm{mm})\end{array}$ \\
\hline E-1 & 0,65 & 13,7 & 57,4 & 47,50 & 190 \\
\hline E-2 & 0,59 & 13,5 & 49,5 & 54,50 & 218 \\
\hline E-3 & 0,76 & 11,5 & 62,6 & 45,00 & 180 \\
\hline E-4 & 0,74 & 12,0 & 62,9 & 49,50 & 198 \\
\hline E-5 & 0,69 & 11,8 & 57,2 & 48,50 & 194 \\
\hline
\end{tabular}

Tabela 4.11 - Ensaios com 8 parafusos paralelos às fibras - Eucalipto Grandis

\begin{tabular}{|c|c|c|c|c|c|}
\hline \multirow{2}{*}{$\begin{array}{c}\mathrm{N}^{\mathrm{o}} \text { - do } \\
\text { corpo de } \\
\text { prova }\end{array}$} & \multicolumn{3}{|c|}{ Características do corpo-de-prova } & \multirow{2}{*}{$\begin{array}{c}\text { Força de } \\
\text { ruptura } \\
(\mathrm{kN})\end{array}$} & \multirow{2}{*}{$\begin{array}{c}\text { Resistência } \\
\text { (N/mm) }\end{array}$} \\
\hline & $\begin{array}{c}\text { Massa específica } \\
\left(\mathrm{g} / \mathrm{cm}^{3}\right)\end{array}$ & $\begin{array}{c}\text { Teor de umidade } \\
\text { em } \%\end{array}$ & $\begin{array}{c}\mathrm{f}_{\mathrm{c}, 0} \\
(\mathrm{MPa})\end{array}$ & & \\
\hline E-6 & 0,74 & 12,2 & 60,1 & 77,50 & 155 \\
\hline E-7 & 0,59 & 12,4 & 49,4 & 79,00 & 158 \\
\hline E-8 & 0,72 & 11,7 & 53,1 & 82,00 & 164 \\
\hline E-9 & 0,72 & 12,4 & 63,5 & 79,50 & 159 \\
\hline E-10 & 0,73 & 12,5 & 57,7 & 87,50 & 175 \\
\hline
\end{tabular}


Tabela 4.12 - Ensaios com 16 parafusos paralelos às fibras - Eucalipto Grandis

\begin{tabular}{|c|c|c|c|c|c|}
\hline \multirow{2}{*}{$\begin{array}{c}\mathrm{N}^{\mathrm{o}} \text { - do } \\
\text { corpo de } \\
\text { prova }\end{array}$} & \multicolumn{3}{|c|}{ Características do corpo-de-prova } & \multirow{2}{*}{$\begin{array}{c}\text { Força de } \\
\text { ruptura } \\
(\mathrm{kN})\end{array}$} & \multirow{2}{*}{$\begin{array}{c}\text { Resistência } \\
(\mathrm{N} / \mathrm{mm})\end{array}$} \\
\hline & $\begin{array}{c}\text { Massa específica } \\
\left(\mathrm{g} / \mathrm{cm}^{3}\right)\end{array}$ & $\begin{array}{c}\text { Teor de umidade } \\
\text { em } \%\end{array}$ & $\begin{array}{c}\mathrm{f}_{\mathrm{c}, 0} \\
(\mathrm{MPa})\end{array}$ & & \\
\hline E-11 & 0,76 & 11,8 & 61,6 & 162,00 & 162 \\
\hline E-12 & 0,66 & 13,5 & 49,6 & 156,00 & 156 \\
\hline E-13 & 0,77 & 13,6 & 63,4 & 165,50 & 166 \\
\hline E-14 & 0,71 & 12,5 & 56,2 & 172,00 & 172 \\
\hline E-15 & 0,73 & 12,1 & 56,7 & 175,00 & 175 \\
\hline
\end{tabular}

Tabela 4.13 - Ensaios com 4 parafusos perpendiculares às fibras - Eucalipto Grandis

\begin{tabular}{|c|c|c|c|c|c|}
\hline \multirow{2}{*}{$\begin{array}{c}\mathrm{N}^{0} \text { - do } \\
\text { corpo de } \\
\text { prova }\end{array}$} & \multicolumn{2}{|c|}{ Características do corpo-de-prova } & \multirow{2}{*}{$\begin{array}{c}\text { Força de } \\
\text { ruptura } \\
\left(\mathrm{g} / \mathrm{cm}^{3}\right)\end{array}$} & $\begin{array}{c}\text { Resistência } \\
(\mathrm{N} / \mathrm{mm})\end{array}$ & \\
\hline E-16 & 0,69 & 13,6 & 48,1 & 63,30 & 253 \\
\hline E-17 & 0,64 & 13,2 & 55,4 & 65,20 & 261 \\
\hline E-18 & 0,70 & 11,7 & 44,6 & 60,80 & 243 \\
\hline E-19 & 0,73 & 13,6 & 53,3 & 67,00 & 268 \\
\hline E-20 & 0,69 & 12,9 & 53,6 & 66,10 & 264 \\
\hline
\end{tabular}

Tabela 4.14 - Ensaios com 8 parafusos perpendiculares às fibras - Eucalipto Grandis

\begin{tabular}{|c|c|c|c|c|c|}
\hline \multirow{2}{*}{$\begin{array}{c}\mathrm{N}^{\mathrm{o}} \text { - do } \\
\text { corpo de } \\
\text { prova }\end{array}$} & \multicolumn{2}{|c|}{ Características do corpo-de-prova } & \multirow{2}{*}{$\begin{array}{c}\text { Força de } \\
\text { ruptura } \\
\left(\mathrm{g} / \mathrm{cm}^{3}\right)\end{array}$} & $\begin{array}{c}\text { Massa específica } \\
\text { em \% }\end{array}$ & $\begin{array}{c}\text { Teor de umidade } \\
(\mathrm{N} / \mathrm{mm})\end{array}$ \\
\hline E-21 & 0,69 & 13,4 & 53,5 & 70,50 & 141 \\
\hline E-22 & 0,77 & 13,0 & 55,1 & 63,50 & 127 \\
\hline E-23 & 0,74 & 11,8 & 61,0 & 69,00 & 138 \\
\hline E-24 & 0,77 & 13,4 & 55,5 & 54,50 & 109 \\
\hline E-25 & 0,71 & 12,7 & 51,9 & 74,50 & 149 \\
\hline
\end{tabular}




\subsection{3 - Cupiúba}

As tabelas 4.15 a 4.19 apresentam os resultados obtidos para a espécie Cupiúba. Nestes ensaios, a pré-furação é igual a 6,0 mm e o comprimento de rosca inserida é igual a $70 \mathrm{~mm}$.

Tabela 4.15 - Ensaios com 4 parafusos paralelos às fibras - Cupiúba

\begin{tabular}{|c|c|c|c|c|c|}
\hline \multirow{2}{*}{$\begin{array}{c}\mathrm{N}^{\mathrm{o}} \text { - do } \\
\text { corpo de } \\
\text { prova }\end{array}$} & \multicolumn{2}{|c|}{ Características do corpo-de-prova } & $\begin{array}{c}\text { Força de } \\
\text { ruptura } \\
\left(\mathrm{g} / \mathrm{cm}^{3}\right)\end{array}$ & $\begin{array}{c}\text { Massa específica } \\
\text { em } \%\end{array}$ & $\begin{array}{c}\text { Teor de umidade } \\
(\mathrm{N} / \mathrm{mm})\end{array}$ \\
\hline C-1 & 0,79 & 9,1 & 53,4 & 64,50 & 258 \\
\hline C-2 & 0,78 & 14,2 & 60,0 & 43,50 & 174 \\
\hline C-3 & 0,83 & 11,5 & 52,2 & 47,50 & 190 \\
\hline C-4 & 0,72 & 12,7 & 61,3 & 47,00 & 188 \\
\hline C-5 & 0,75 & 10,9 & 53,5 & 54,50 & 218 \\
\hline
\end{tabular}

Tabela 4.16 - Ensaios com 8 parafusos paralelos às fibras - Cupiúba

\begin{tabular}{|c|c|c|c|c|c|}
\hline $\begin{array}{c}\mathrm{N}^{\mathrm{o}} \text { - do } \\
\text { corpo de } \\
\text { prova }\end{array}$ & \multicolumn{2}{|c|}{ Características do corpo-de-prova } & $\begin{array}{c}\text { Força de } \\
\text { ruptura } \\
\left(\mathrm{g} / \mathrm{cm}^{3}\right)\end{array}$ & $\begin{array}{c}\text { Massa específica } \\
(\mathrm{kN})\end{array}$ & $\begin{array}{c}\text { Resistência } \\
(\mathrm{N} / \mathrm{mm})\end{array}$ \\
\hline C-6 & 0,79 & 10,5 & 54,7 & 89,50 & 179 \\
\hline $\mathrm{C}-7$ & 0,78 & 15,8 & 49,7 & 74,00 & 148 \\
\hline $\mathrm{C}-8$ & 0,82 & 12,9 & 66,1 & 72,50 & 145 \\
\hline $\mathrm{C}-9$ & 0,73 & 12,1 & 62,5 & 87,50 & 175 \\
\hline $\mathrm{C}-10$ & 0,73 & 14,1 & 53,5 & 78,50 & 157 \\
\hline
\end{tabular}


Tabela 4.17 - Ensaios com 16 parafusos paralelos às fibras - Cupiúba

\begin{tabular}{|c|c|c|c|c|c|}
\hline \multirow{2}{*}{$\begin{array}{c}\mathrm{N}^{\mathrm{o}} \text { - do } \\
\text { corpo de } \\
\text { prova }\end{array}$} & \multicolumn{2}{|c|}{ Características do corpo-de-prova } & \multirow{2}{*}{$\begin{array}{c}\text { Força de } \\
\text { ruptura } \\
\left(\mathrm{g} / \mathrm{cm}^{3}\right)\end{array}$} & $\begin{array}{c}\text { Massa específica } \\
\text { em } \%\end{array}$ & $\begin{array}{c}\text { Teor de umidade } \\
(\mathrm{N} / \mathrm{mm})\end{array}$ \\
\hline $\mathrm{C}-11$ & 0,78 & 12,5 & 59,9 & 171,50 & 172 \\
\hline $\mathrm{C}-12$ & 0,78 & 10,8 & 48,4 & 137,50 & 138 \\
\hline $\mathrm{C}-13$ & 0,79 & 8,2 & 50,0 & 154,50 & 155 \\
\hline $\mathrm{C}-14$ & 0,73 & 11,4 & 48,9 & 164,50 & 165 \\
\hline $\mathrm{C}-15$ & 0,77 & 12,6 & 38,6 & 158,50 & 159 \\
\hline
\end{tabular}

Tabela 4.18 - Ensaios com 4 parafusos perpendiculares às fibras - Cupiúba

\begin{tabular}{|c|c|c|c|c|c|}
\hline \multirow{2}{*}{$\begin{array}{c}\mathrm{N}^{0} \text { - do } \\
\text { corpo de } \\
\text { prova }\end{array}$} & \multicolumn{3}{|c|}{ Características do corpo-de-prova } & \multirow{2}{*}{$\begin{array}{c}\text { Força de } \\
\text { ruptura } \\
(\mathrm{kN})\end{array}$} & \multirow{2}{*}{$\begin{array}{c}\text { Resistência } \\
\text { (N/mm) }\end{array}$} \\
\hline & $\begin{array}{c}\text { Massa específica } \\
\qquad\left(\mathrm{g} / \mathrm{cm}^{3}\right)\end{array}$ & $\begin{array}{c}\text { Teor de umidade } \\
\text { em } \%\end{array}$ & $\begin{array}{c}\mathrm{f}_{\mathrm{c}, 0} \\
(\mathrm{MPa})\end{array}$ & & \\
\hline C-16 & 0,75 & 9,4 & 52,0 & 67,00 & 268 \\
\hline $\mathrm{C}-17$ & 0,76 & 11,2 & 46,9 & 60,50 & 242 \\
\hline C-18 & 0,95 & 18,6 & 52,0 & 54,50 & 218 \\
\hline C-19 & 0,86 & 13,6 & 51,3 & 65,50 & 262 \\
\hline C-20 & 0,90 & 17,1 & 41,3 & 55,00 & 220 \\
\hline
\end{tabular}

Tabela 4.19 - Ensaios com 8 parafusos perpendiculares às fibras - Cupiúba

\begin{tabular}{|c|c|c|c|c|c|}
\hline \multirow{2}{*}{$\begin{array}{l}\mathrm{N}^{\mathrm{o}} \text { - do } \\
\text { corpo de } \\
\text { prova }\end{array}$} & \multicolumn{3}{|c|}{ Características do corpo-de-prova } & \multirow{2}{*}{$\begin{array}{c}\text { Força de } \\
\text { ruptura } \\
(\mathrm{kN})\end{array}$} & \multirow{2}{*}{$\begin{array}{c}\text { Resistência } \\
\text { (N/mm) }\end{array}$} \\
\hline & $\begin{array}{c}\text { Massa específica } \\
\qquad\left(\mathrm{g} / \mathrm{cm}^{3}\right)\end{array}$ & $\begin{array}{c}\text { Teor de umidade } \\
\text { em } \%\end{array}$ & $\begin{array}{c}\mathrm{f}_{\mathrm{c}, 0} \\
(\mathrm{MPa})\end{array}$ & & \\
\hline $\mathrm{C}-21$ & 0,77 & 11,8 & 51,7 & 84,50 & 169 \\
\hline $\mathrm{C}-22$ & 0,76 & 10,6 & 33,8 & 55,00 & 110 \\
\hline $\mathrm{C}-23$ & 0,85 & 16,4 & 55,3 & 73,50 & 147 \\
\hline $\mathrm{C}-24$ & 0,69 & 14,4 & 57,8 & 72,50 & 145 \\
\hline $\mathrm{C}-25$ & 0,72 & 17,1 & 44,0 & 62,50 & 125 \\
\hline
\end{tabular}




\section{3 - ENSAIOS SECUNDÁRIOS}

\subsection{1 - Pinus Taeda}

As tabelas 4.20 a 4.23 apresentam os resultados obtidos variando-se a massa específica da madeira. As tabelas 4.24 a 4.26 apresentam os resultados variando-se o espaçamento entre os parafusos. Nestes ensaios, a pré-furação é igual a 5,5 $\mathrm{mm}$ e o comprimento de rosca inserida é igual a $80 \mathrm{~mm}$..

Tabela 4.20 - Menor massa específica - 4 parafusos paralelos às fibras - Pinus Taeda

\begin{tabular}{|c|c|c|c|c|c|}
\hline \multirow{2}{*}{$\begin{array}{c}\mathrm{N}^{\mathrm{O}} \text {. do } \\
\text { corpo de } \\
\text { prova }\end{array}$} & \multicolumn{3}{|c|}{ Características do corpo-de-prova } & \multirow{2}{*}{$\begin{array}{c}\text { Força de } \\
\text { ruptura } \\
(\mathrm{kN})\end{array}$} & \multirow{2}{*}{$\begin{array}{c}\text { Resistência } \\
\text { (N/mm) }\end{array}$} \\
\hline & $\begin{array}{c}\text { Massa específica } \\
\left(\mathrm{g} / \mathrm{cm}^{3}\right)\end{array}$ & $\begin{array}{c}\text { Teor de umidade } \\
\text { em } \%\end{array}$ & $\begin{array}{c}\mathrm{f}_{\mathrm{c}, 0} \\
(\mathrm{MPa})\end{array}$ & & \\
\hline P-26 & 0,46 & 12,1 & 51,5 & 52,50 & 181 \\
\hline P-27 & 0,44 & 11,2 & 49,7 & 46,50 & 160 \\
\hline P-28 & 0,45 & 11,8 & 52,3 & 50,50 & 174 \\
\hline P-29 & 0,43 & 10,5 & 48,6 & 46,50 & 160 \\
\hline P-30 & 0,43 & 11,6 & 58,2 & 51,00 & 176 \\
\hline
\end{tabular}

Tabela 4.21 - Maior massa específica - 4 parafusos paralelos às fibras - Pinus Taeda

\begin{tabular}{|c|c|c|c|c|c|}
\hline \multirow{2}{*}{$\begin{array}{c}\mathrm{N}^{\mathrm{o}} \text {. do } \\
\text { corpo de } \\
\text { prova }\end{array}$} & \multicolumn{3}{|c|}{ Características do corpo-de-prova } & \multirow{2}{*}{$\begin{array}{c}\text { Força de } \\
\text { ruptura } \\
(\mathrm{kN})\end{array}$} & \multirow{2}{*}{$\begin{array}{c}\text { Resistência } \\
\text { (N/mm) }\end{array}$} \\
\hline & $\begin{array}{c}\text { Massa específica } \\
\qquad\left(\mathrm{g} / \mathrm{cm}^{3}\right)\end{array}$ & $\begin{array}{c}\text { Teor de umidade } \\
\text { em } \%\end{array}$ & $\begin{array}{c}\mathrm{f}_{\mathrm{c}, 0} \\
(\mathrm{MPa})\end{array}$ & & \\
\hline $\mathrm{P}-31$ & 0,49 & 10,1 & 48,5 & 51,80 & 179 \\
\hline $\mathrm{P}-32$ & 0,56 & 10,4 & 48,7 & 49,50 & 171 \\
\hline $\mathrm{P}-33$ & 0,54 & 11,3 & 48,6 & 54,70 & 189 \\
\hline $\mathrm{P}-34$ & 0,50 & 10,1 & 54,1 & 45,50 & 157 \\
\hline $\mathrm{P}-35$ & 0,50 & 11,2 & 46,9 & 43,30 & 149 \\
\hline
\end{tabular}


Tabela 4.22 - Menor massa específica - 4 parafusos perpendiculares às fibras - Pinus Taeda

\begin{tabular}{|c|c|c|c|c|c|}
\hline \multirow{2}{*}{$\begin{array}{c}\mathrm{N}^{\mathrm{o}} \text { - do } \\
\text { corpo de } \\
\text { prova }\end{array}$} & \multicolumn{2}{|c|}{ Características do corpo-de-prova } & \multirow{2}{*}{$\begin{array}{c}\text { Força de } \\
\text { ruptura } \\
\left(\mathrm{g} / \mathrm{cm}^{3}\right)\end{array}$} & $\begin{array}{c}\text { Massa específica } \\
\text { em } \%\end{array}$ & $\begin{array}{c}\text { Teor de umidade } \\
(\mathrm{N} / \mathrm{mm})\end{array}$ \\
\hline P-36 & 0,44 & 11,8 & 32,5 & 54,50 & 188 \\
\hline P-37 & 0,43 & 12,1 & 40,7 & 43,50 & 150 \\
\hline P-38 & 0,41 & 12,4 & 46,2 & 35,20 & 121 \\
\hline P-39 & 0,41 & 12,9 & 36,6 & 35,70 & 123 \\
\hline P-40 & 0,40 & 12,8 & 40,9 & 32,30 & 111 \\
\hline
\end{tabular}

Tabela 4.23 - Maior massa específica - 4 parafusos perpendiculares às fibras - Pinus Taeda

\begin{tabular}{|c|c|c|c|c|c|}
\hline \multirow{2}{*}{$\begin{array}{c}\mathrm{N}^{\mathrm{o}} \text {. do } \\
\text { corpo de } \\
\text { prova }\end{array}$} & \multicolumn{3}{|c|}{ Características do corpo-de-prova } & \multirow{2}{*}{$\begin{array}{c}\text { Força de } \\
\text { ruptura } \\
(\mathrm{kN})\end{array}$} & \multirow{2}{*}{$\begin{array}{c}\text { Resistência } \\
\text { (N/mm) }\end{array}$} \\
\hline & $\begin{array}{c}\text { Massa específica } \\
\left(\mathrm{g} / \mathrm{cm}^{3}\right)\end{array}$ & $\begin{array}{c}\text { Teor de umidade } \\
\text { em } \%\end{array}$ & $\begin{array}{c}\mathrm{f}_{\mathrm{c}, 0} \\
(\mathrm{MPa})\end{array}$ & & \\
\hline $\mathrm{P}-41$ & 0,51 & 11,5 & 43,7 & 51,30 & 177 \\
\hline P-42 & 0,45 & 11,4 & 39,2 & 42,30 & 146 \\
\hline $\mathrm{P}-43$ & 0,45 & $\overline{11,1}$ & 45,4 & 43,00 & 148 \\
\hline P-44 & 0,47 & 11,5 & 44,4 & 54,60 & 188 \\
\hline $\mathrm{P}-45$ & 0,48 & 12,6 & 45,8 & 37,20 & 128 \\
\hline
\end{tabular}

Tabela 4.24 - Espaçamento de $15 \mathrm{~mm}$ entre parafusos - 4 parafusos paralelos às fibras -

Pinus Taeda

\begin{tabular}{|c|c|c|c|c|c|}
\hline \multirow{2}{*}{$\begin{array}{c}\mathrm{N}^{\mathrm{o}} \text {. do } \\
\text { corpo de } \\
\text { prova }\end{array}$} & \multicolumn{3}{|c|}{ Características do corpo-de-prova } & \multirow{2}{*}{$\begin{array}{c}\text { Força de } \\
\text { ruptura } \\
(\mathrm{kN})\end{array}$} & \multirow{2}{*}{$\begin{array}{c}\text { Resistência } \\
\text { (N/mm) }\end{array}$} \\
\hline & $\begin{array}{c}\text { Massa específica } \\
\left(\mathrm{g} / \mathrm{cm}^{3}\right)\end{array}$ & $\begin{array}{c}\text { Teor de umidade } \\
\text { em } \%\end{array}$ & $\begin{array}{c}\mathrm{f}_{\mathrm{c}, 0} \\
(\mathrm{MPa})\end{array}$ & & \\
\hline $\mathrm{P}-46$ & 0,44 & 9,8 & 51,0 & 41,50 & 143 \\
\hline $\mathrm{P}-47$ & 0,48 & 10,8 & 48,0 & 51,40 & 177 \\
\hline $\mathrm{P}-48$ & 0,49 & 8,7 & 44,5 & 54,20 & 187 \\
\hline $\mathrm{P}-49$ & 0,46 & 8,5 & 47,7 & 42,50 & 147 \\
\hline $\mathrm{P}-50$ & 0,48 & 9,2 & 46,7 & 50,40 & 174 \\
\hline
\end{tabular}


Tabela 4.25 - Espaçamento de $30 \mathrm{~mm}$ entre parafusos - 4 parafusos paralelos às fibras Pinus Taeda

\begin{tabular}{|c|c|c|c|c|c|}
\hline \multirow{2}{*}{$\begin{array}{c}\mathrm{N}^{0} \text { - do } \\
\text { corpo de } \\
\text { prova }\end{array}$} & \multicolumn{2}{|c|}{ Características do corpo-de-prova } & \multirow{2}{*}{$\begin{array}{c}\text { Força de } \\
\text { ruptura } \\
\left(\mathrm{g} / \mathrm{cm}^{3}\right)\end{array}$} & $\begin{array}{c}\text { Resistência } \\
(\mathrm{N} / \mathrm{mm})\end{array}$ & \\
\cline { 2 - 4 } & $\begin{array}{c}\text { Massa específica } \\
\text { P-51 }\end{array}$ & $\begin{array}{c}\text { Teor de umidade } \\
\mathrm{f}_{\mathrm{c}, 0} \\
(\mathrm{MPa})\end{array}$ & 50,6 & 44,50 & 153 \\
\hline P-52 & 0,48 & 8,1 & 55,4 & 41,00 & 141 \\
\hline P-53 & 0,51 & 9,7 & 47,0 & 44,20 & 152 \\
\hline P-54 & 0,48 & 8,6 & 50,3 & 43,50 & 150 \\
\hline P-55 & 0,42 & 9,0 & 48,6 & 45,60 & 157 \\
\hline
\end{tabular}

Tabela 4.26 - Espaçamento de $45 \mathrm{~mm}$ entre parafusos - 4 parafusos paralelos às fibras Pinus Taeda

\begin{tabular}{|c|c|c|c|c|c|}
\hline \multirow{2}{*}{$\begin{array}{l}\mathrm{N}^{\mathrm{O}} \text { - do } \\
\text { corpo de } \\
\text { prova }\end{array}$} & \multicolumn{3}{|c|}{ Características do corpo-de-prova } & \multirow{2}{*}{$\begin{array}{c}\text { Força de } \\
\text { ruptura } \\
(\mathrm{kN})\end{array}$} & \multirow{2}{*}{$\begin{array}{c}\text { Resistência } \\
\text { (N/mm) }\end{array}$} \\
\hline & $\begin{array}{c}\text { Massa específica } \\
\left(\mathrm{g} / \mathrm{cm}^{3}\right)\end{array}$ & $\begin{array}{c}\text { Teor de umidade } \\
\text { em } \%\end{array}$ & $\begin{array}{c}\mathrm{f}_{\mathrm{c}, 0} \\
(\mathrm{MPa})\end{array}$ & & \\
\hline P-56 & 0,50 & 10,0 & 42,4 & 51,00 & 176 \\
\hline P-57 & 0,47 & 9,4 & 46,9 & 46,20 & 159 \\
\hline P-58 & 0,49 & 9,9 & 51,1 & 51,00 & 176 \\
\hline P-59 & 0,49 & 7,1 & 48,5 & 43,00 & 148 \\
\hline P-60 & 0,54 & 9,6 & 50,2 & 56,00 & 193 \\
\hline
\end{tabular}




\subsection{2 - Eucalipto Grandis}

As tabelas 4.27 a 4.30 apresentam os resultados obtidos variando-se a massa específica da madeira. As tabelas 4.31 a 4.34 apresentam os resultados obtidos para o teor de umidade em torno de $20 \%$ e acima do ponto de saturação. Nestes ensaios, a pré-furação é igual a 6,0 mm e o comprimento de rosca inserida é igual a $70 \mathrm{~mm}$.

Tabela 4.27 - Menor massa específica - 4 parafusos paralelos às fibras - Eucalipto Grandis

\begin{tabular}{|c|c|c|c|c|c|}
\hline \multirow{2}{*}{$\begin{array}{c}\mathrm{N}^{\mathrm{o}} \text { - do } \\
\text { corpo de } \\
\text { prova }\end{array}$} & \multicolumn{2}{|c|}{ Características do corpo-de-prova } & \multirow{2}{*}{$\begin{array}{c}\text { Força de } \\
\text { ruptura } \\
\left(\mathrm{g} / \mathrm{cm}^{3}\right)\end{array}$} & $\begin{array}{c}\text { Massa específica } \\
\text { em } \%\end{array}$ & $\begin{array}{c}\text { Teor de umidade } \\
(\mathrm{N} / \mathrm{mm})\end{array}$ \\
\hline E-26 & 0,65 & 15,2 & 53,3 & 40,00 & 160 \\
\hline E-27 & 0,66 & 12,9 & 53,5 & 42,50 & 170 \\
\hline E-28 & 0,63 & 13,1 & 43,0 & 46,50 & 186 \\
\hline E-29 & 0,68 & 13,2 & 58,8 & 45,00 & 180 \\
\hline E-30 & 0,69 & 15,4 & 47,2 & 51,50 & 206 \\
\hline
\end{tabular}

Tabela 4.28 - Maior massa específica - 4 parafusos paralelos às fibras - Eucalipto Grandis

\begin{tabular}{|c|c|c|c|c|c|}
\hline $\mathrm{N}^{0}$. do & \multicolumn{3}{|c|}{ Características do corpo-de-prova } & \multirow{2}{*}{$\begin{array}{c}\text { Força de } \\
\text { ruptura } \\
(\mathrm{kN})\end{array}$} & \multirow{2}{*}{$\begin{array}{c}\text { Resistência } \\
\text { (N/mm) }\end{array}$} \\
\hline $\begin{array}{c}\text { corpo de } \\
\text { prova }\end{array}$ & $\begin{array}{c}\text { Massa específica } \\
\left(\mathrm{g} / \mathrm{cm}^{3}\right)\end{array}$ & $\begin{array}{c}\text { Teor de umidade } \\
\text { em } \%\end{array}$ & $\begin{array}{c}\mathrm{f}_{\mathrm{c}, 0} \\
(\mathrm{MPa})\end{array}$ & & \\
\hline E-31 & 0,73 & 12,2 & 47,1 & 49,00 & 196 \\
\hline E-32 & 0,75 & 12,6 & 56,7 & 39,00 & 156 \\
\hline E-33 & 0,70 & 13,1 & 50,5 & 50,50 & 202 \\
\hline E-34 & 0,80 & 13,5 & 62,9 & 52,50 & 210 \\
\hline E-35 & 0,74 & 12,5 & 48,4 & 52,00 & 208 \\
\hline
\end{tabular}


Tabela 4.29 - Menor massa específica - 4 parafusos perpendiculares às fibras - Eucalipto Grandis

\begin{tabular}{|c|c|c|c|c|c|}
\hline \multirow{2}{*}{$\begin{array}{c}\mathrm{N}^{0} \text { - do } \\
\text { corpo de } \\
\text { prova }\end{array}$} & \multicolumn{2}{|c|}{ Características do corpo-de-prova } & $\begin{array}{c}\text { Força de } \\
\text { ruptura }(\mathrm{kN})\end{array}$ & $\begin{array}{c}\text { Resistência } \\
(\mathrm{N} / \mathrm{mm})\end{array}$ \\
\hline E-36 & 0,69 & 12,5 & 54,4 & 68,00 & 272 \\
\hline E-37 & 0,67 & 13,9 & 56,1 & 69,00 & 276 \\
\hline E-38 & 0,67 & 11,1 & 55,3 & 55,10 & 220 \\
\hline E-39 & 0,64 & 11,7 & 58,6 & 56,00 & 224 \\
\hline E-40 & 0,68 & 13,8 & 51,3 & 64,00 & 256 \\
\hline
\end{tabular}

Tabela 4.30 - Maior massa específica - 4 parafusos perpendiculares às fibras - Eucalipto Grandis

\begin{tabular}{|c|c|c|c|c|c|}
\hline \multirow{2}{*}{$\begin{array}{c}\mathrm{N}^{\mathrm{o}} \text {. do } \\
\text { corpo de } \\
\text { prova }\end{array}$} & \multicolumn{3}{|c|}{ Características do corpo-de-prova } & \multirow{2}{*}{$\begin{array}{c}\text { Força de } \\
\text { ruptura } \\
(\mathrm{kN})\end{array}$} & \multirow{2}{*}{$\begin{array}{c}\text { Resistência } \\
\text { (N/mm) }\end{array}$} \\
\hline & $\begin{array}{c}\text { Massa específica } \\
\qquad\left(\mathrm{g} / \mathrm{cm}^{3}\right)\end{array}$ & $\begin{array}{c}\text { Teor de umidade } \\
\text { em } \%\end{array}$ & $\begin{array}{c}\mathrm{f}_{\mathrm{c}, 0} \\
(\mathrm{MPa})\end{array}$ & & \\
\hline E-41 & 0,72 & 12,2 & 57,4 & 67,00 & 268 \\
\hline E-42 & 0,71 & 10,7 & 55,5 & 69,00 & 276 \\
\hline E-43 & 0,71 & 14,4 & 58,6 & 66,00 & 264 \\
\hline E-44 & 0,70 & 11,7 & 59,3 & 69,40 & 278 \\
\hline E-45 & 0,74 & 13,8 & 56,1 & 56,00 & 224 \\
\hline
\end{tabular}

Tabela 4.31 - Umidade: $20 \%$ - 4 parafusos paralelos às fibras - Eucalipto Grandis

\begin{tabular}{|c|c|c|c|c|c|}
\hline \multirow{2}{*}{$\begin{array}{c}\mathrm{N}^{\mathrm{o}} \text {. do } \\
\text { corpo de } \\
\text { prova }\end{array}$} & \multicolumn{3}{|c|}{ Características do corpo-de-prova } & \multirow{2}{*}{$\begin{array}{c}\text { Força de } \\
\text { ruptura } \\
(\mathrm{kN})\end{array}$} & \multirow{2}{*}{$\begin{array}{c}\text { Resistência } \\
\text { (N/mm) }\end{array}$} \\
\hline & $\begin{array}{c}\text { Massa específica } \\
\left(\mathrm{g} / \mathrm{cm}^{3}\right)\end{array}$ & $\begin{array}{c}\text { Teor de umidade } \\
\text { em } \%\end{array}$ & $\begin{array}{c}\mathrm{f}_{\mathrm{c}, 0} \\
(\mathrm{MPa})\end{array}$ & & \\
\hline E-46 & 0,69 & 22,3 & 46,2 & 31,50 & 126 \\
\hline E-47 & 0,68 & 20,9 & 39,7 & 35,55 & 143 \\
\hline E-48 & 0,70 & 22,1 & 45,4 & 37,50 & 150 \\
\hline E-49 & 0,71 & 22,4 & 46,7 & 40,40 & 162 \\
\hline E-50 & 0,63 & 23,0 & 43,9 & 35,70 & 143 \\
\hline
\end{tabular}


Tabela 4.32 - Ponto de saturação - 4 parafusos paralelos às fibras - Eucalipto Grandis

\begin{tabular}{|c|c|c|c|c|c|}
\hline \multirow{2}{*}{$\begin{array}{c}\mathrm{N}^{\mathrm{o}} \text { - do } \\
\text { corpo de } \\
\text { prova }\end{array}$} & \multicolumn{3}{|c|}{ Características do corpo-de-prova } & \multirow{2}{*}{$\begin{array}{c}\text { Força de } \\
\text { ruptura } \\
(\mathrm{kN})\end{array}$} & \multirow{2}{*}{$\begin{array}{c}\text { Resistência } \\
\text { (N/mm) }\end{array}$} \\
\hline & $\begin{array}{c}\text { Massa específica } \\
\left(\mathrm{g} / \mathrm{cm}^{3}\right)\end{array}$ & $\begin{array}{c}\text { Teor de umidade } \\
\text { em } \%\end{array}$ & $\begin{array}{c}\mathrm{f}_{\mathrm{c}, 0} \\
(\mathrm{MPa})\end{array}$ & & \\
\hline E-51 & 0,69 & 29,5 & 45,2 & 36,70 & 147 \\
\hline E-52 & 0,66 & 31,3 & 36,5 & 33,90 & 136 \\
\hline E-53 & 0,77 & 25,0 & 45,6 & 35,20 & 141 \\
\hline E-54 & 0,77 & 24,7 & 44,8 & 30,90 & 124 \\
\hline E-55 & 0,67 & 25,3 & 42,8 & 34,42 & 138 \\
\hline
\end{tabular}

Tabela 4.33 - Umidade: 20\% - 4 parafusos perpendiculares às fibras - Eucalipto Grandis

\begin{tabular}{|c|c|c|c|c|c|}
\hline \multirow{2}{*}{$\begin{array}{c}\mathrm{N}^{\mathrm{o}} \text {. do } \\
\text { corpo de } \\
\text { prova }\end{array}$} & \multicolumn{3}{|c|}{ Características do corpo-de-prova } & \multirow{2}{*}{$\begin{array}{c}\text { Força de } \\
\text { ruptura } \\
(\mathrm{kN})\end{array}$} & \multirow{2}{*}{$\begin{array}{c}\text { Resistência } \\
\text { (N/mm) }\end{array}$} \\
\hline & $\begin{array}{c}\text { Massa específica } \\
\qquad\left(\mathrm{g} / \mathrm{cm}^{3}\right)\end{array}$ & $\begin{array}{c}\text { Teor de umidade } \\
\text { em } \%\end{array}$ & $\begin{array}{c}\mathrm{f}_{\mathrm{c}, 0} \\
(\mathrm{MPa})\end{array}$ & & \\
\hline E-56 & 0,67 & 22,8 & 42,8 & 60,00 & 240 \\
\hline E-57 & 0,71 & 22,7 & 39,2 & 51,50 & 206 \\
\hline E-58 & 0,71 & 22,0 & 45,4 & 63,50 & 254 \\
\hline E-59 & 0,67 & 21,5 & 46,7 & 58,60 & 234 \\
\hline E-60 & 0,65 & 20,7 & 48,8 & 61,00 & 244 \\
\hline
\end{tabular}

Tabela 4.34 - Ponto de saturação - 4 parafusos perpendiculares às fibras - Eucalipto Grandis

\begin{tabular}{|c|c|c|c|c|c|}
\hline \multirow{2}{*}{$\begin{array}{c}\mathrm{N}^{\mathrm{O}} \text {. do } \\
\text { corpo de } \\
\text { prova }\end{array}$} & \multicolumn{3}{|c|}{ Características do corpo-de-prova } & \multirow{2}{*}{$\begin{array}{c}\text { Força de } \\
\text { ruptura } \\
(\mathrm{kN})\end{array}$} & \multirow{2}{*}{$\begin{array}{c}\text { Resistência } \\
\text { (N/mm) }\end{array}$} \\
\hline & $\begin{array}{c}\text { Massa específica } \\
\left(\mathrm{g} / \mathrm{cm}^{3}\right)\end{array}$ & $\begin{array}{c}\text { Teor de umidade } \\
\text { em } \%\end{array}$ & $\begin{array}{c}\mathrm{f}_{\mathrm{c}, 0} \\
(\mathrm{MPa})\end{array}$ & & \\
\hline E-61 & 0,67 & 24,9 & 43,3 & 59,10 & 236 \\
\hline E-62 & 0,65 & 24,8 & 42,5 & 56,20 & 225 \\
\hline E-63 & 0,72 & 24,7 & 38,8 & 61,00 & 244 \\
\hline E-64 & 0,71 & 24,4 & 41,3 & 65,30 & 261 \\
\hline E-65 & 0,71 & 24,1 & 40,1 & 55,60 & 222 \\
\hline
\end{tabular}




\section{ANÁLISE DOS RESULTADOS}

\section{1 - ENSAIOS PRELIMINARES}

Os primeiros ensaios, apresentados na tabela 4.1, foram realizados com o objetivo de determinar o comprimento adequado de rosca a ser inserida no corpo-de-prova para realização dos ensaios subseqüentes.

Para os corpos-de-prova Cp-1 a Cp-3, que têm um maior comprimento de rosca inserida no corpo-de-prova, ocorreu a ruptura da cabeça do parafuso. Para os ensaios dos corpos-de-prova Cp-4 e Cp-5 ocorreram à ruptura da ligação, ou seja, ocorreu cisalhamento na interface entre a madeira e o parafuso.

Desta forma, adotou-se o comprimento de rosca a ser inserida no corpo-de-prova como sendo igual a $80 \mathrm{~mm}$.

Após isso, foram realizados ensaios para verificar se ocorria variação na resistência da ligação, ao se alterar a pré-furação e o comprimento de rosca inserida na madeira, para as três espécies em estudo. As tabelas 4.3 e 4.4 apresentam os resultados para estas ligações.

Com os valores das resistências em N/mm, obtidos a partir do comprimento de rosca efetivo, realizou-se uma análise estatística, utilizando-se o software MINITAB for WINDOWS - Release 10, por meio de regressão linear com os seguintes fatores:

- Pré-furação

- Comprimento de rosca efetivo

- Espécie de madeira

- Interação entre pré-furação e comprimento de rosca efetivo

- Interação entre pré-furação e espécie de madeira

- Interação entre comprimento de rosca inserida e espécie de madeira

- Interação entre pré-furação, comprimento de rosca efetivo e espécie de madeira

A tabela 5.1 apresenta os resultados obtidos na análise de variância da regressão: 
Tabela 5.1 - Análise da variância para verificação da influência dos fatores

\begin{tabular}{cccccc}
\hline Fonte de variação & $\begin{array}{c}\text { Graus de } \\
\text { liberdade }\end{array}$ & $\begin{array}{c}\text { Soma dos } \\
\text { quadrados }\end{array}$ & $\begin{array}{c}\text { Quadrados } \\
\text { médios }\end{array}$ & $\mathrm{F}$ & $\mathrm{P}$ \\
\hline Pré-furação - (1) & 1 & 6778,8 & 6778,8 & 12,07 & 0,003 \\
Prof. de rosca - (2) & 2 & 1133,6 & 566,8 & 1,01 & 0,384 \\
Madeira - (3) & 2 & 45050,4 & 22525,2 & 40,12 & 0,000 \\
Interação - (1) e (2) & 2 & 293,6 & 146,8 & 0,26 & 0,773 \\
Interação - (1) e (3) & 2 & 477,4 & 238,7 & 0,43 & 0,660 \\
Interação - (2) e (3) & 4 & 2041,3 & 510,3 & 0,91 & 0,480 \\
Interação - (1), (2) e (3) & 4 & 483,3 & 120,8 & 0,22 & 0,927 \\
Resíduo & 18 & 10107 & 561,5 & & \\
\hline
\end{tabular}

A figura 5.1 apresenta o gráfico de resíduos $\mathrm{x}$ valores estimados obtidos da regressão, permitindo observar a distribuição aleatória dos resíduos em torno de zero.

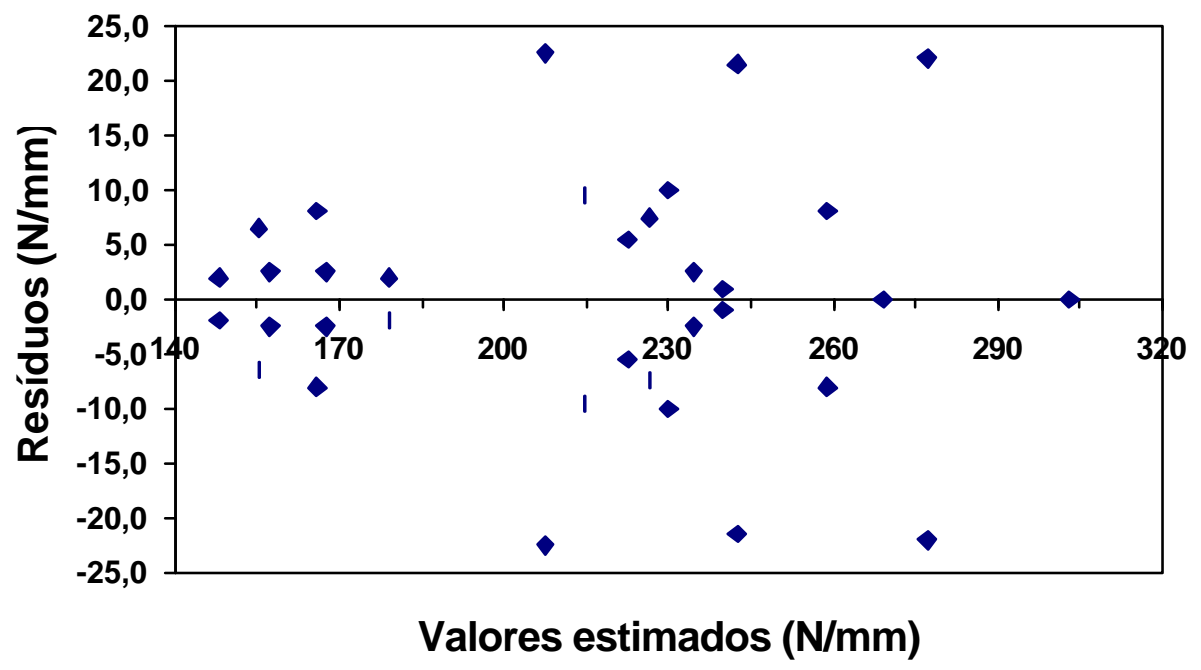

Figura 5.1 - Análise dos resíduos - Variação de resistência.

A análise estatística efetuada permite concluir, com nível de confiança acima de 95\%, que existe influência apenas dos fatores espécie de madeira e diâmetro da pré-furação, não existindo influência significativa para o fator comprimento de rosca e das interações entre os fatores. 
Para proporcionar uma melhor comparação do efeito da pré-furação, a tabela 5.2 apresenta a média dos resultados da resistência de cada espécie, em função da pré-furação, considerando que o fator comprimento de rosca efetivo não apresentou influência significativa.

Tabela 5.2 - Média das resistências em função da pré-furação

\begin{tabular}{|c|c|c|}
\hline Espécie de madeira & $\begin{array}{c}\text { Resistência com } \\
\text { Pré-furação de } 5,5 \mathrm{~mm} \\
(\mathrm{~N} / \mathrm{mm})\end{array}$ & $\begin{array}{c}\text { Resistência com } \\
\text { Pré-furação de 6,0 mm } \\
(\mathrm{N} / \mathrm{mm})\end{array}$ \\
\hline Pinus Taeda & 171 & 154 \\
\hline Eucalipto Grandis & 258 & 229 \\
\hline Cupiúba & 253 & 221 \\
\hline
\end{tabular}

Considerando-se os resultados obtidos nos ensaios preliminares, adotou-se uma préfuração com diâmetro igual $5,5 \mathrm{~mm}$, para a realização dos ensaios principais e secundários para a espécie Pinus Taeda, pois este valor conduz a melhores resultados de resistência, cerca de $11 \%$ superior em relação à pré-furação de $6,0 \mathrm{~mm}$. Para esta espécie, foi adotado um comprimento de rosca inserida na madeira igual a $80 \mathrm{~mm}$.

Para as espécies Eucalipto Grandis e Cupiúba, adotou-se uma pré-furação com diâmetro igual a 6,0 mm, apesar disto conduzir a valores inferiores (cerca de $11 \%$ e $13 \%$ respectivamente), por possibilitar uma maior facilidade de execução da ligação para estas espécies, que são mais densas. Foi adotado um comprimento de rosca inserida na madeira igual a $70 \mathrm{~mm}$, garantindo, desta forma, que a ruptura sempre ocorra na ligação e não nos parafusos.

Para o cálculo da resistência, é considerado o comprimento de rosca efetivo. As medidas são respectivamente: $72,5 \mathrm{~mm}$ para a espécie Pinus Taeda e $62,5 \mathrm{~mm}$ para o Eucalipto Grandis e Cupiúba.

\section{2 - ENSAIOS PRINCIPAIS}

Com os valores de resistências obtidos dos ensaios principais realizou-se uma análise estatística, utilizando-se o software MINITAB for WINDOWS - Release 10, por meio de regressão linear com os seguintes fatores: 
- Grupo de 4, 8 e 16 parafusos fixos paralelos às fibras

- Espécies de madeira

A tabela 5.3 apresenta os resultados obtidos na análise de variância da regressão:

Tabela 5.3 - Análise da variância para grupos de parafusos paralelos às fibras

\begin{tabular}{cccccc}
\hline $\begin{array}{c}\text { Fonte de } \\
\text { variação }\end{array}$ & $\begin{array}{c}\text { Graus de } \\
\text { liberdade }\end{array}$ & $\begin{array}{c}\text { Soma dos } \\
\text { quadrados }\end{array}$ & $\begin{array}{c}\text { Quadrados } \\
\text { médios }\end{array}$ & $\mathrm{F}$ & $\mathrm{P}$ \\
\hline Grupo de & 2 & 12985,6 & 6492,8 & 25,46 & 0,000 \\
parafusos & & & & & \\
Madeira & 2 & 8275,2 & 4137,6 & 16,22 & 0,000 \\
Resíduo & 40 & 10201,7 & 255 & & \\
\hline
\end{tabular}

A figura 5.2 apresenta o gráfico de resíduos $\mathrm{x}$ valores estimados obtidos da regressão.

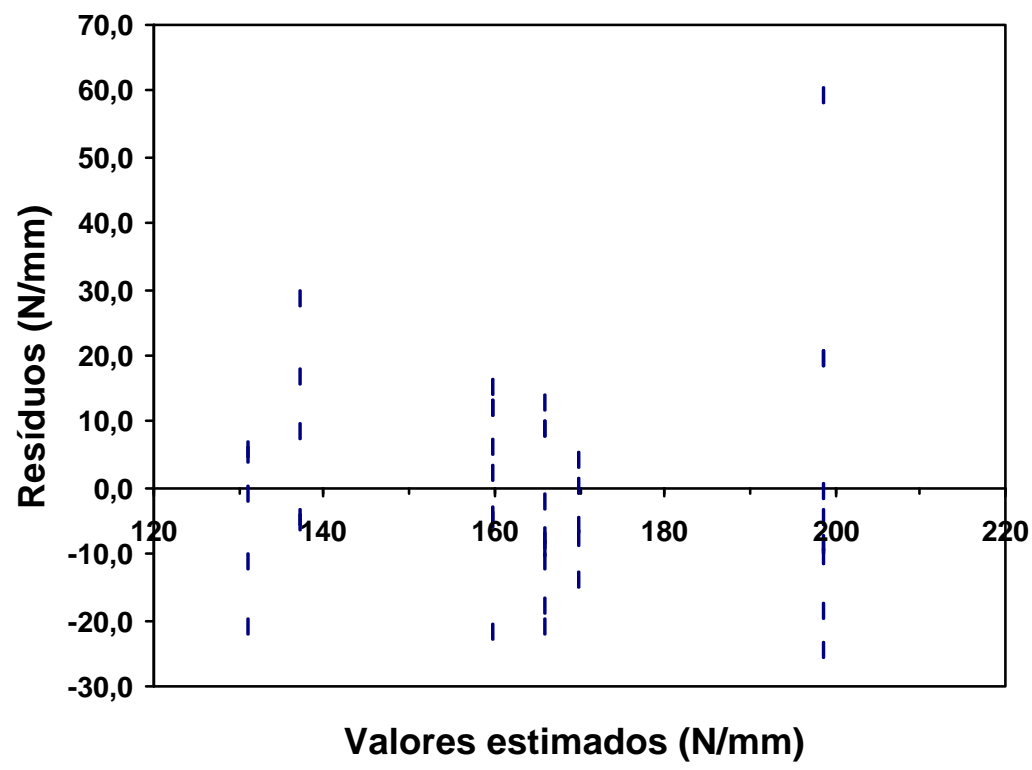

Figura 5.2 - Análise dos resíduos - Grupo de parafusos paralelos às fibras.

A análise indicou a presença de um ponto com alto valor de resíduo, observado na figura 5.2.

Portanto, este ponto foi extraído para se realizar uma nova análise que é apresentada na tabela 5.4. 
Tabela 5.4 - Análise da variância para grupos de parafusos paralelos às fibras - Corrigido

\begin{tabular}{cccccc}
\hline $\begin{array}{c}\text { Fonte de } \\
\text { variação }\end{array}$ & $\begin{array}{c}\text { Graus de } \\
\text { liberdade }\end{array}$ & $\begin{array}{c}\text { Soma dos } \\
\text { quadrados }\end{array}$ & $\begin{array}{c}\text { Quadrados } \\
\text { médios }\end{array}$ & F & P \\
\hline Grupo de & 2 & 9284,8 & 4770,7 & 29,92 & 0,000 \\
parafusos & & & & & \\
Madeira & 2 & 7148,6 & 3574,3 & 22,42 & 0,000 \\
Resíduo & 39 & 6217,4 & 159,4 & & \\
\hline
\end{tabular}

A nova apresentação do gráfico de resíduos $\mathrm{x}$ valores estimados obtidos da regressão figura 5.3, permite observar a distribuição aleatória dos resíduos em torno de zero.

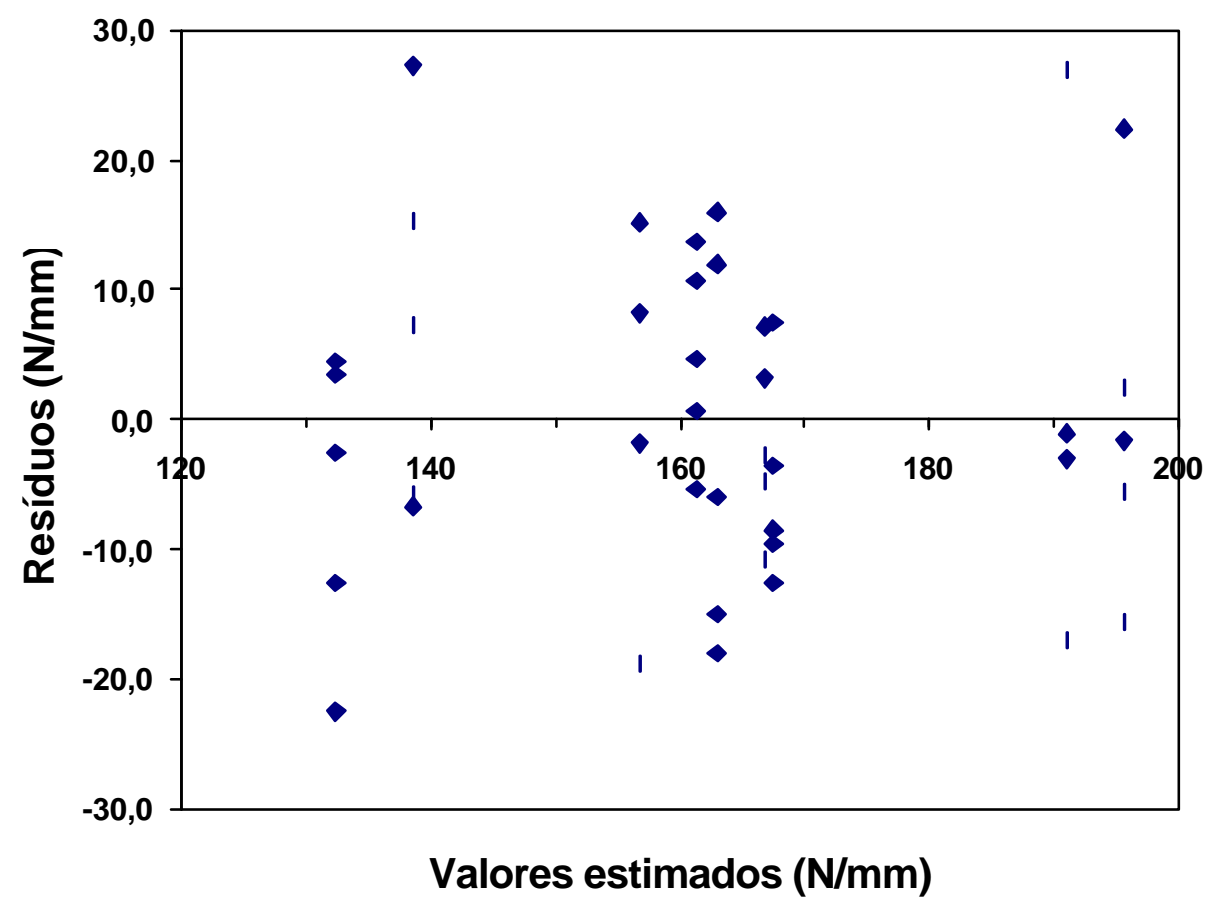

Figura 5.3 - Análise dos resíduos - Grupo de parafusos paralelos às fibras - Corrigido.

A análise estatística efetuada permite concluir que existe influência significativa do número de parafusos na resistência.

A seguir, a tabela 5.5 apresenta um resumo dos resultados dos valores médios da resistência nas espécies de madeira em estudo para grupos de parafusos fixos paralelamente às fibras. 
Tabela 5.5 - Resistência $(\mathrm{N} / \mathrm{mm})$ para parafusos fixos paralelamente às fibras

\begin{tabular}{|c|c|c|c|}
\hline \multirow{2}{*}{$\begin{array}{c}\text { Número de } \\
\text { parafusos }\end{array}$} & Pinus Taeda & Eucalipto Grandis & Cupiúba \\
\cline { 2 - 4 } & & & 196 \\
\hline 4 & 165 & 162 & 206 \\
\hline 8 & 146 & 166 & 161 \\
\hline 16 & 127 & 158 \\
\hline
\end{tabular}

Ao comparar a resistência dos parafusos em ligações que utilizam 4, 8 e 16 parafusos fixos paralelos às fibras para a espécie Pinus Taeda, observa-se que o valor médio da resistência do parafuso nas ligações formadas por 16 parafusos é 23,03\% menor do que em ligações formadas por 4 parafusos. Para ligações com 8 parafusos, o valor médio da resistência é 11,51\% menor do que em ligações formadas por 4 parafusos. Para a espécie do Eucalipto Grandis, o valor médio da resistência do parafuso nas ligações formadas por 16 parafusos é 15,31\% menor do que em ligações formadas por 4 parafusos. Para ligações com 8 parafusos, o valor médio da resistência é 17,34\% menor do que em ligações formadas por 4 parafusos. Nas ligações com a espécie Cupiúba, o valor médio da resistência do parafuso nas ligações formadas por 16 parafusos é 23,30\% menor do que em ligações formadas por 4 parafusos. Para ligações com 8 parafusos o valor médio da resistência é 21,84\% menor do que em ligações formadas por 4 parafusos. Com base nestes resultados, sugere-se coeficiente de redução da resistência igual a 0,75 , no caso da ligação ter mais de 4 parafusos fixos paralelos às fibras.

Para ligações formadas por grupos de parafusos fixos perpendicularmente às fibras, não é possível fazer uma análise mais detalhada dos resultados pois, na maioria dos casos, ocorreu a ruptura do corpo-de-prova por flexão, e não a ruptura da ligação por cisalhamento na interface entre a madeira e o parafuso, inviabilizando a comparação das resistências obtidas como já foi exposto no capítulo 4 na página 50. A tabela 5.6 apresenta um resumo dos resultados dos valores médios da resistência nas espécies de madeira em estudo para grupos de parafusos fixos perpendicularmente. Pode-se afirmar que a resistência da ligação é superior aos valores apresentados, pelos motivos expostos anteriormente.

Tabela 5.6 - Resistência $(\mathrm{N} / \mathrm{mm})$ para parafusos fixos perpendicularmente às fibras

\begin{tabular}{|c|c|c|c|}
\hline \multirow{2}{*}{$\begin{array}{c}\text { Número de } \\
\text { parafusos }\end{array}$} & \multicolumn{3}{|c|}{ Espécie de madeira } \\
\cline { 2 - 4 } & Pinus Taeda & Eucalipto Grandis & Cupiúba \\
\hline 4 & 174 & 258 & 242 \\
\hline 8 & 109 & 133 & 139 \\
\hline
\end{tabular}




\section{3 - ENSAIOS SECUNDÁRIOS}

Para a análise dos resultados secundários, utilizou-se o software MINITAB for WINDOWS - Release 10, com o qual realizou-se análise estatística por meio de regressão linear.

Devido ao modo de ruptura que ocorreu nos corpos-de-prova com grupos de parafusos fixos perpendicularmente às fibras, não é possível fazer uma análise mais detalhada dos resultados, como já foi exposto anteriormente.

\subsection{1 - Avaliação da Influência da Massa Específica}

A partir dos resultados obtidos, a tabela 5.7 apresenta um resumo dos valores médios da massa específica, umidade e da resistência para a espécie Pinus Taeda.

Tabela 5.7 - Resistência para parafusos fixos paralelamente às fibras - Pinus Taeda.

\begin{tabular}{|c|c|c|c|}
\hline $\begin{array}{c}\text { Número de } \\
\text { parafusos }\end{array}$ & $\begin{array}{c}\text { Massa específica } \\
\left(\mathrm{g} / \mathrm{cm}^{3}\right)\end{array}$ & $\begin{array}{c}\text { Teor de umidade } \\
(\%)\end{array}$ & Resistência $(\mathrm{N} / \mathrm{mm})$ \\
\hline 4 & 0,44 (menor) & 11,4 & 170 \\
\hline 4 & 0,51 (maior) & 10,6 & 169 \\
\hline
\end{tabular}

Para a espécie Pinus Taeda, a variação entre os valores médios das massas específicas menor e maior é em torno de $13 \%$, sendo que os valores médios da resistência variam menos de $1 \%$.

Com os valores das resistências das ligações para parafusos fixos paralelamente, realizou-se uma análise estatística por meio de regressão linear. A tabela 5.8 apresenta os resultados obtidos na análise de variância da regressão para os parafusos fixos paralelamente, na espécie Pinus Taeda:

Tabela 5.8 - Influência da massa específica - Pinus Taeda

\begin{tabular}{cccccc}
\hline Fonte de variação & $\begin{array}{c}\text { Graus de } \\
\text { liberdade }\end{array}$ & $\begin{array}{c}\text { Soma dos } \\
\text { quadrados }\end{array}$ & $\begin{array}{c}\text { Quadrados } \\
\text { médios }\end{array}$ & $\mathrm{F}$ & $\mathrm{P}$ \\
\hline $\begin{array}{c}\text { Variação de massa } \\
\text { específica }\end{array}$ & 1 & 4 & 4 & 0,02 & 0,890 \\
Resíduo & 8 & 1421 & 178 & & \\
\hline
\end{tabular}


A figura 5.4 apresenta o gráfico de resíduos $\mathrm{x}$ valores estimados obtidos da regressão.

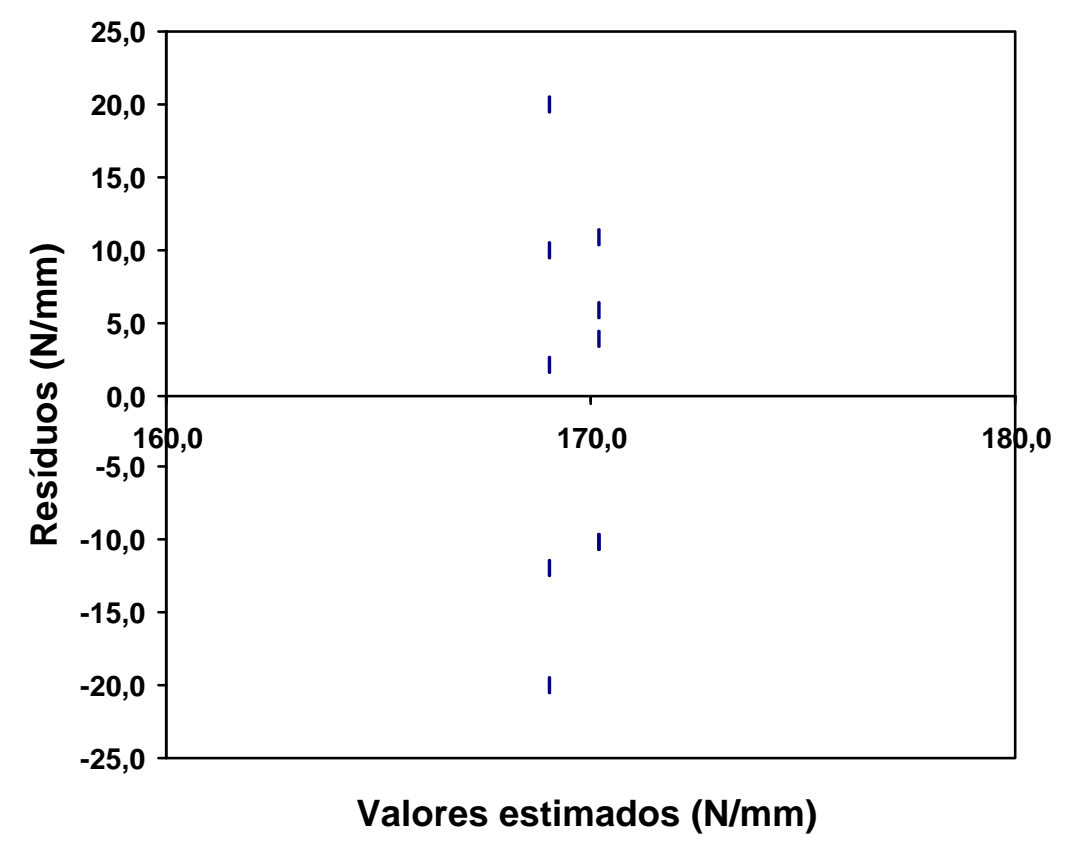

Figura 5.4 - Análise dos resíduos - Variação de massa específica - Pinus Taeda.

A análise estatística efetuada permite concluir que não há influência da variação da massa específica nos valores da resistência, para a espécie Pinus Taeda.

A tabela 5.9 apresenta um resumo dos valores médios da massa específica, do teor de umidade e da resistência para a espécie Eucalipto Grandis.

Tabela 5.9 - Resistência para parafusos fixos paralelamente às fibras - Eucalipto Grandis.

\begin{tabular}{|c|c|c|c|}
\hline $\begin{array}{c}\text { Número de } \\
\text { parafusos }\end{array}$ & $\begin{array}{c}\text { Massa específica } \\
\left(\mathrm{g} / \mathrm{cm}^{3}\right)\end{array}$ & $\begin{array}{c}\text { Teor de umidade } \\
(\%)\end{array}$ & Resistência (N/mm) \\
\hline 4 & 0,66 (menor) & 14,0 & 184 \\
\hline 4 & 0,74 (maior) & 12,8 & 194 \\
\hline
\end{tabular}

A variação do valor médio das massas específica menor e maior para a espécie Eucalipto Grandis é de 9\%, ficando a diferença da média da resistência entre corpos-deprova com massa específica menor e massa específica maior utilizando parafusos fixos paralelos às fibras igual a 5\%.

A tabela 5.10 apresenta os resultados obtidos na análise de variância da regressão para os parafusos fixos paralelamente, com a espécie Eucalipto Grandis: 
Tabela 5.10 - Influência da massa específica - Eucalipto Grandis

\begin{tabular}{cccccc}
\hline Fonte de variação & $\begin{array}{c}\text { Graus de } \\
\text { liberdade }\end{array}$ & $\begin{array}{c}\text { Soma dos } \\
\text { quadrados }\end{array}$ & $\begin{array}{c}\text { Quadrados } \\
\text { médios }\end{array}$ & F & P \\
\hline $\begin{array}{c}\text { Variação de massa } \\
\text { específica }\end{array}$ & 1 & 480 & 490 & 1,23 & 0,299 \\
Resíduo & 8 & 3174 & 397 & & \\
\hline
\end{tabular}

A figura 5.5 apresenta o gráfico de resíduos x valores estimados.

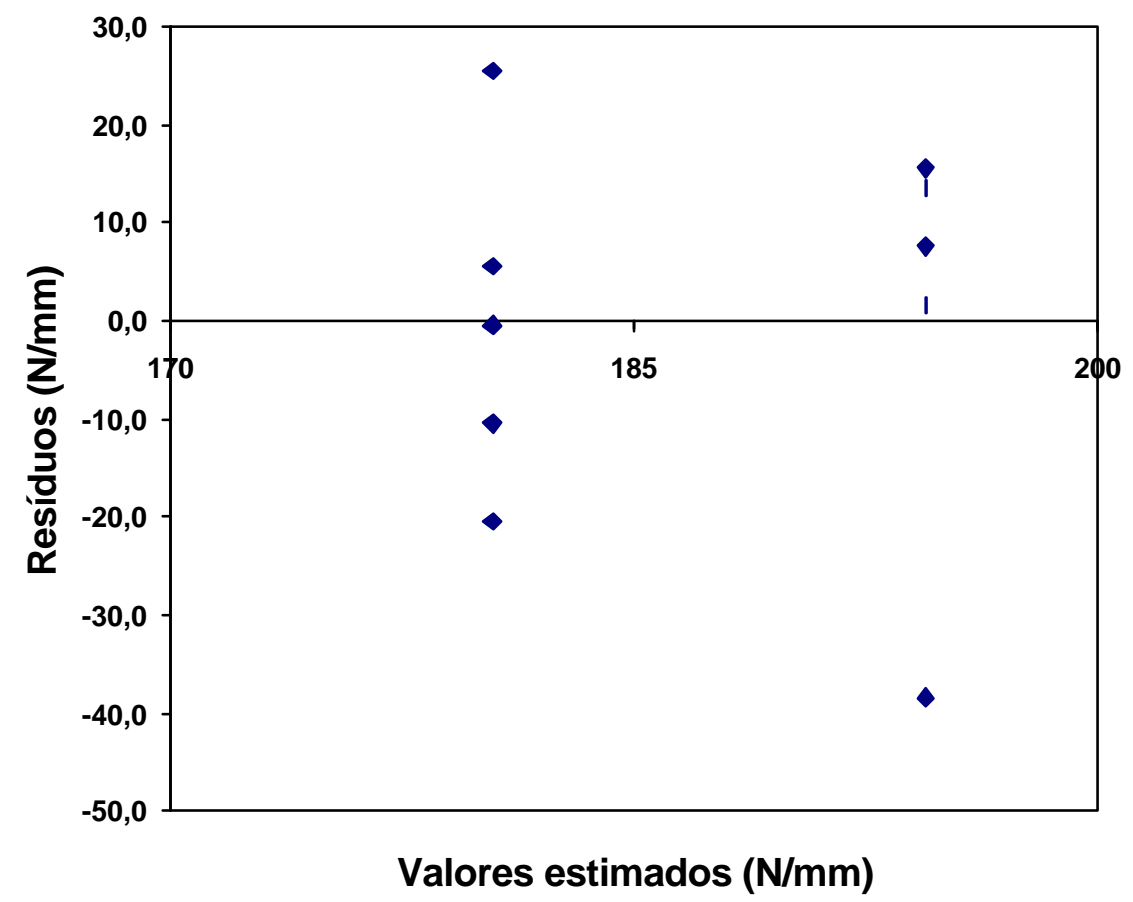

Figura 5.5 - Análise dos resíduos - Variação de massa específica - Eucalipto Grandis.

Para a espécie Eucalipto Grandis, a primeira análise da variância realizada indicou a presença de dois pontos com alto valor de resíduo. Portanto, estes pontos foram extraídos para se realizar uma nova análise que é apresentada na tabela 5.11. 
Tabela 5.11 - Influência da massa específica - Eucalipto Grandis - Corrigido

\begin{tabular}{cccccc}
\hline Fonte de variação & $\begin{array}{c}\text { Graus de } \\
\text { liberdade }\end{array}$ & $\begin{array}{c}\text { Soma dos } \\
\text { quadrados }\end{array}$ & $\begin{array}{c}\text { Quadrados } \\
\text { médios }\end{array}$ & $\mathrm{F}$ & $\mathrm{P}$ \\
\hline $\begin{array}{c}\text { Variação de massa } \\
\text { específica }\end{array}$ & 1 & 1800 & 1800 & 21,09 & 0,004 \\
Resíduo & 6 & 512 & 85,3 & & \\
\hline
\end{tabular}

A figura 5.6 apresenta o gráfico de resíduos $\mathrm{x}$ valores estimados obtidos da regressão.

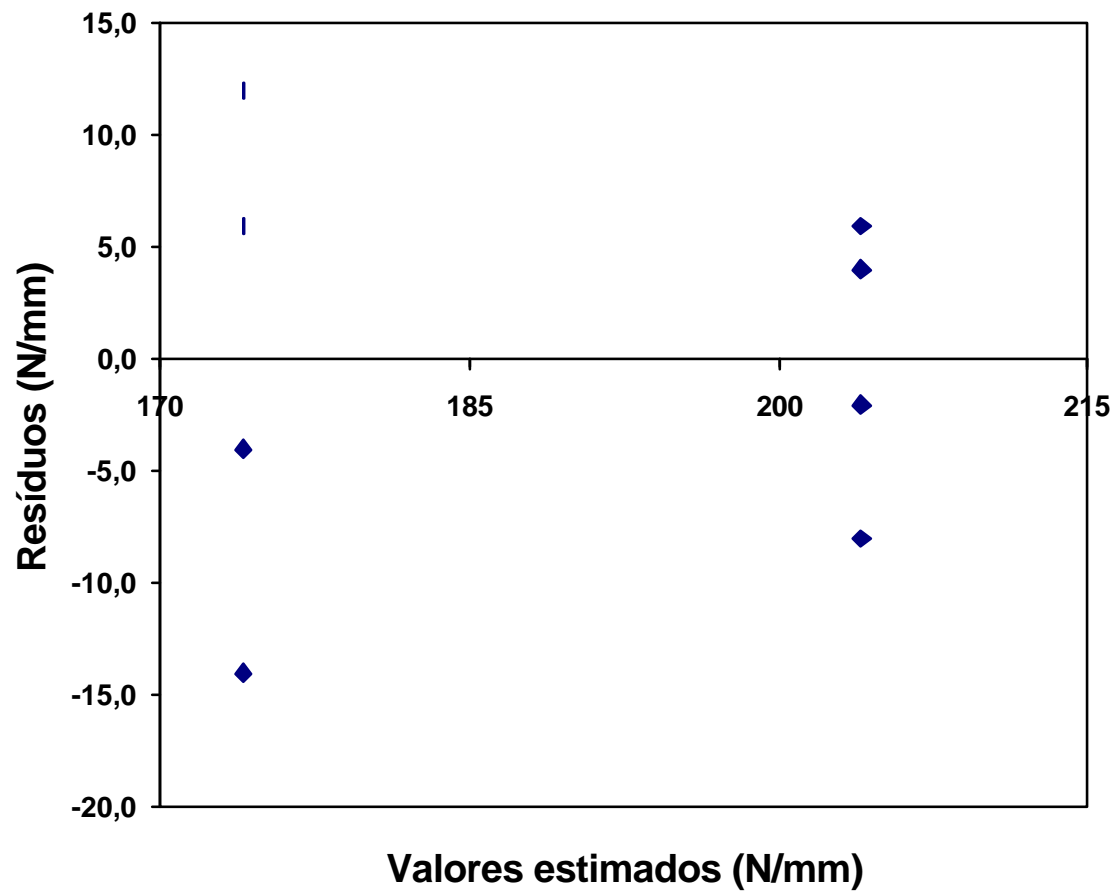

Figura 5.6 - Análise dos resíduos corrigidos - Variação de massa específica -

Eucalipto Grandis.

A análise estatística efetuada permite concluir, com nível de confiança acima de 95\%, que existe influência significativa nos valores da resistência ao variar a massa específica na espécie Eucalipto Grandis.

Com a nova análise estatística os valores da resistência são alterados, estando estes valores apresentados na tabela 5.12. 
Tabela 5.12 - Resistência média corrigida - Parafusos paralelos às fibras - Eucalipto Grandis

\begin{tabular}{|cl|c|c|}
\hline \multicolumn{2}{|c|}{ Número de parafusos } & $\begin{array}{c}\text { Resistência } \\
\text { média }(\mathrm{N} / \mathrm{mm})\end{array}$ & $\begin{array}{c}\text { Resistência média corrigida - (N/mm) } \\
\text { ao retirar pontos altos de resíduos }\end{array}$ \\
\hline 4 & (Menor massa específica) & 184 & 174 \\
\hline 4 & (Maior massa específica) & 194 & 204 \\
\hline
\end{tabular}

As variações entre os valores das resistências são: para a menor massa específica ocorre um decréscimo de 5\% no valor inicial da resistência e para a maior massa específica ocorre um acréscimo de 5\% em relação ao valor inicial da resistência ao corrigir os valores.

A análise efetuada indicou haver influência significativa da massa específica, para a espécie Eucalipto Grandis, enquanto que, para a espécie Pinus Taeda, indicou não haver influência significativa deste fator. Isto pode ser creditado à existência, em uma mesma seção do corpo-de-prova, de madeira mais jovem e madeira mais antiga, para a espécie Pinus Taeda. Assim, neste caso, o posicionamento dos parafusos em relação a estes tipos de madeira apresenta maior influência do que o valor da massa específica da madeira.

\subsection{2 - Avaliação da Influência do Teor de Umidade}

A tabela 5.13 apresenta um resumo dos resultados com os valores médios da massa específica, do teor de umidade e da resistência, para a espécie Eucalipto Grandis. Os valores médios referentes à madeira com o teor de umidade em torno de $12 \%$ são referentes aos ensaios principais.

Tabela 5.13 - Resistência para parafusos fixos paralelo às fibras - Eucalipto Grandis.

\begin{tabular}{|c|c|c|c|}
\hline $\begin{array}{c}\text { Número de } \\
\text { parafusos }\end{array}$ & $\begin{array}{c}\text { Massa específica } \\
\left(\mathrm{g} / \mathrm{cm}^{3}\right)\end{array}$ & $\begin{array}{c}\text { Teor de umidade } \\
(\%)\end{array}$ & Resistência (N/mm) \\
\hline 4 & 0,69 & $\cong 12$ & 196 \\
\hline 4 & 0,68 & $\cong 20$ & 145 \\
\hline 4 & 0,71 & Ponto de saturação & 137 \\
\hline
\end{tabular}

Ao variar a umidade da madeira nos corpos-de-prova é possível verificar como este fator interfere de maneira significativa na resistência da ligação. Ao comparar os valores de resistência para teores de umidade de $12 \%$ e $20 \%$, observa-se uma queda de $26 \%$ no valor da resistência. Para teores de umidade entre $12 \%$ e o ponto de saturação ocorre uma queda de $30 \%$ na resistência das ligações com parafusos fixos paralelos às fibras. Com base nos

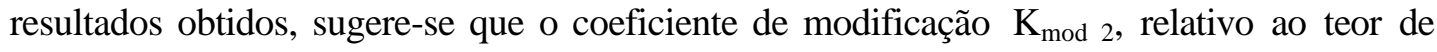
umidade, seja igual a 0,7 para o caso de classes de umidade 3 e 4 da NBR 7190/97. 
A tabela 5.14 apresenta os resultados obtidos na análise de variância da regressão para o fator teor de umidade:

Tabela 5.14 - Influencia do teor de umidade - Eucalipto Grandis

\begin{tabular}{cccccc}
\hline $\begin{array}{c}\text { Fonte de } \\
\text { variação }\end{array}$ & $\begin{array}{c}\text { Graus de } \\
\text { liberdade }\end{array}$ & $\begin{array}{c}\text { Soma dos } \\
\text { quadrados }\end{array}$ & $\begin{array}{c}\text { Quadrados } \\
\text { médios }\end{array}$ & $\mathrm{F}$ & $\mathrm{P}$ \\
\hline $\begin{array}{r}\text { Teor de } \\
\text { umidade }\end{array}$ & 2 & 10228 & 5114 & 34,99 & 0,000 \\
Resíduo & 12 & 1754 & 146 & & \\
\hline
\end{tabular}

A figura 5.7 apresenta o gráfico de resíduos $\mathrm{x}$ valores estimados obtidos da regressão.

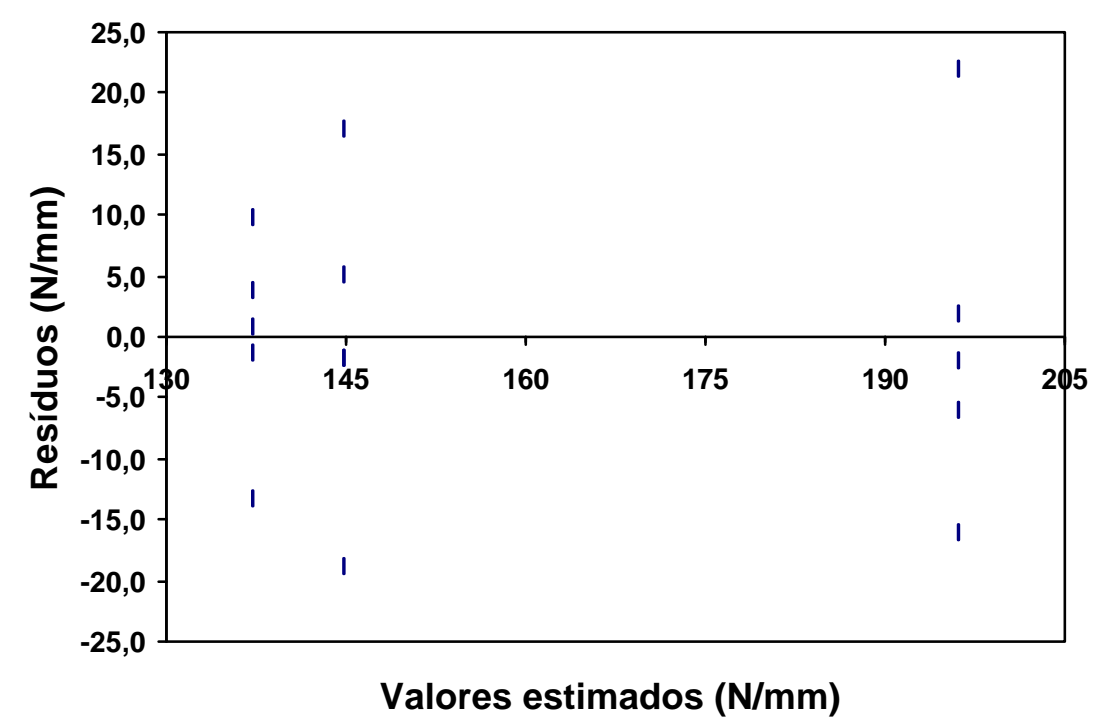

Figura 5.7 - Análise dos resíduos - Variação do teor de umidade - Eucalipto Grandis

A análise estatística efetuada permite concluir, com nível de confiança acima de 95\%, que existe influência significativa ao alterar o teor de umidade da madeira nos valores da resistência.

\subsection{3 - Avaliação da Influência do Espaçamento entre Parafusos}

A tabela 5.15 apresenta os resultados com os valores médios da massa específica, do teor de umidade e da resistência, ao variar os espaçamentos entre os parafusos para a espécie Pinus Taeda. 
Tabela 5.15 - Resistência média em função do espaçamento - parafusos fixos paralelamente às fibras - Pinus Taeda

\begin{tabular}{|c|c|c|c|c|}
\hline $\begin{array}{c}\text { Número } \\
\text { de } \\
\text { parafusos }\end{array}$ & $\begin{array}{c}\text { Espaçamento } \\
(\mathrm{mm})\end{array}$ & $\begin{array}{c}\text { Massa específica } \\
\left(\mathrm{g} / \mathrm{cm}^{3}\right)\end{array}$ & $\begin{array}{c}\text { Teor de umidade } \\
(\%)\end{array}$ & $\begin{array}{c}\text { Resistência } \\
(\mathrm{N} / \mathrm{mm})\end{array}$ \\
\hline 4 & 15 & 0,47 & 9,4 & 166 \\
\hline 4 & 30 & 0,46 & 9,2 & 151 \\
\hline 4 & 45 & 0,50 & 9,2 & 170 \\
\hline
\end{tabular}

Realizou-se a regressão linear com o objetivo de verificar a influência do espaçamento entre os parafusos na resistência. A tabela 5.16 apresenta os resultados obtidos na análise de variância da regressão.

Tabela 5.16 - Influência da variação dos espaçamentos entre parafusos

\begin{tabular}{cccccc}
\hline $\begin{array}{c}\text { Fonte de } \\
\text { variação }\end{array}$ & $\begin{array}{c}\text { Graus de } \\
\text { liberdade }\end{array}$ & $\begin{array}{c}\text { Soma dos } \\
\text { quadrados }\end{array}$ & $\begin{array}{c}\text { Quadrados } \\
\text { médios }\end{array}$ & $\mathrm{F}$ & $\mathrm{P}$ \\
\hline $\begin{array}{c}\text { Grupo de } \\
\text { parafusos }\end{array}$ & 2 & 852 & 426 & 2,18 & 0,156 \\
Resíduo & 12 & 2343 & 195 & & \\
\hline
\end{tabular}

A figura 5.8 apresenta o gráfico de resíduos $\mathrm{x}$ valores estimados obtidos da regressão, permitindo observar a ocorrência de um problema típico, pois a variância aumenta com a resposta.

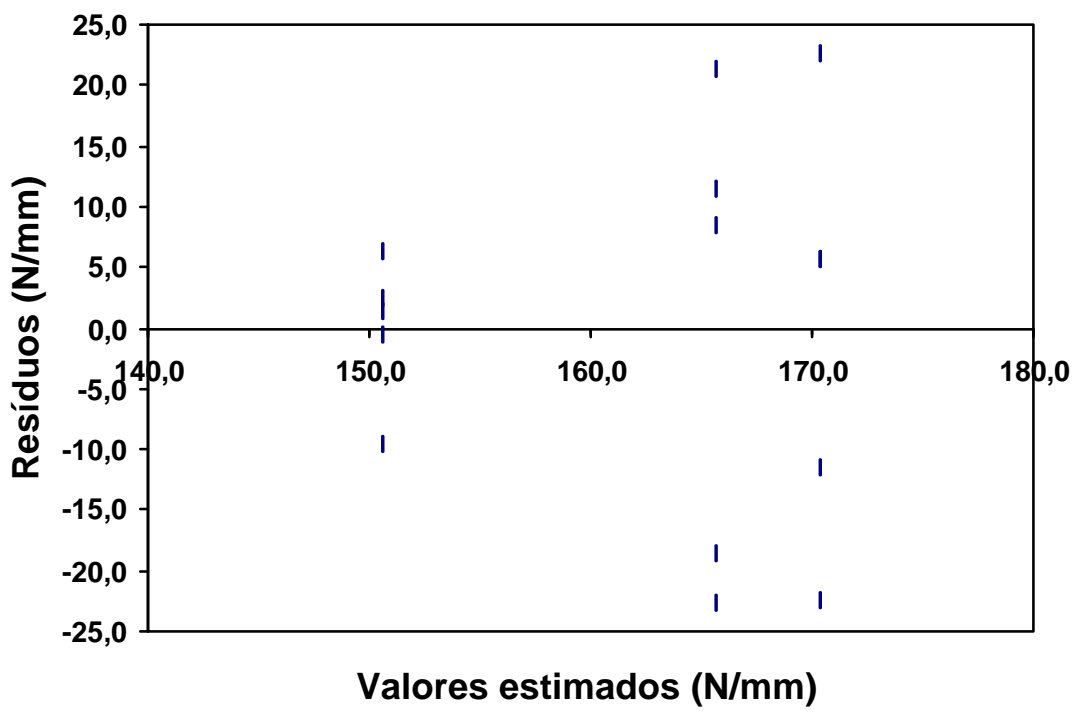

Figura 5.8 - Análise dos resíduos - Variação do espaçamento - Pinus Taeda. 
Portanto, é necessário realizar uma nova análise convertendo os valores dos resultados das resistências em valores logarítmicos. A tabela 5.17 apresenta os resultados após a realização desta conversão.

Tabela 5.17 - Influência da variação dos espaçamentos entre parafusos - Corrigido

\begin{tabular}{cccccc}
\hline $\begin{array}{c}\text { Fonte de } \\
\text { variação }\end{array}$ & $\begin{array}{c}\text { Graus de } \\
\text { liberdade }\end{array}$ & $\begin{array}{c}\text { Soma dos } \\
\text { quadrados }\end{array}$ & $\begin{array}{c}\text { Quadrados } \\
\text { médios }\end{array}$ & $\mathrm{F}$ & $\mathrm{P}$ \\
\hline $\begin{array}{c}\text { Grupo de } \\
\text { parafusos }\end{array}$ & 2 & 0,00737 & 0,00368 & 2,19 & 0,155 \\
Resíduo & 12 & 0,02023 & 0,0169 & & \\
\hline
\end{tabular}

A figura 5.9 apresenta o gráfico de resíduos x valores estimados obtidos da regressão, permitindo observar a distribuição aleatória dos resíduos em torno de zero.

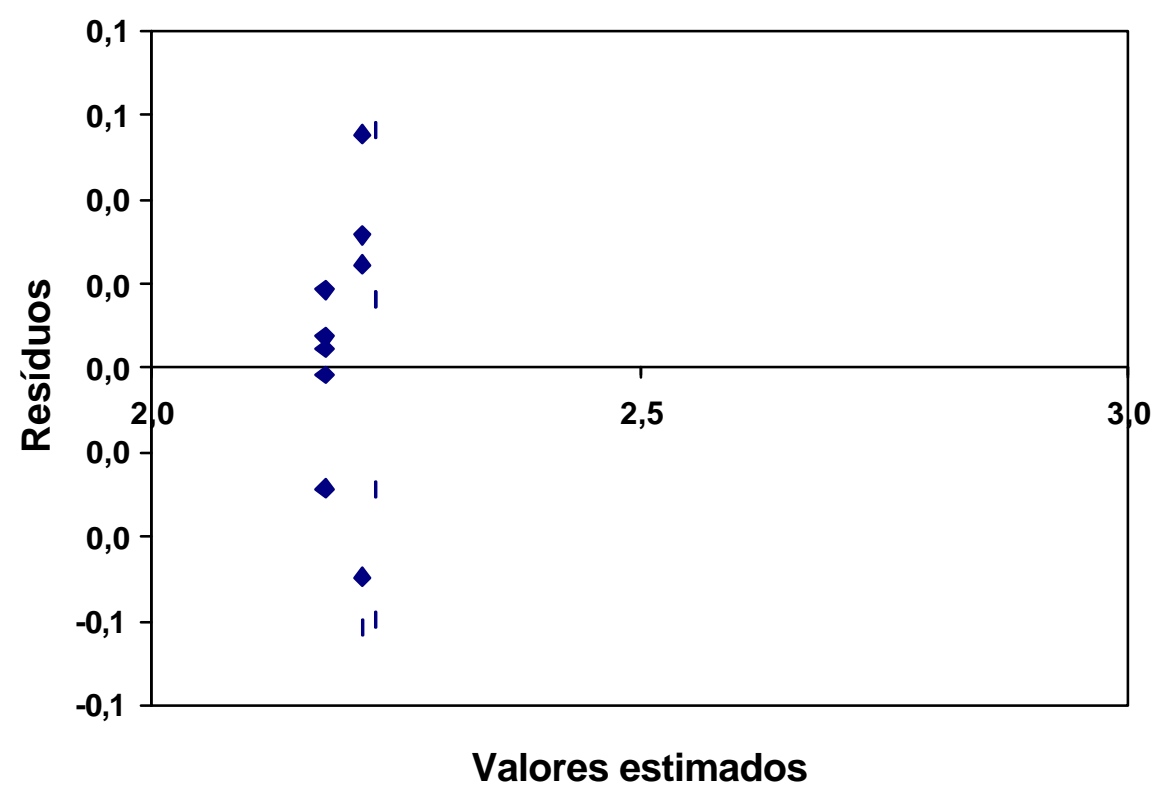

Figura 5.9 - Análise dos resíduos - Variação do espaçamento - Pinus Taeda - Corrigido. 
A análise estatística efetuada permite concluir, com nível de confiança acima de 95\%, que não existe influência significativa nos valores da resistência quando se altera espaçamento entre os parafusos. Portanto ao variar os espaçamentos entre os parafusos torx auto-atarraxantes não há interferência na resistência da ligação, sendo que o mínimo espaçamento utilizado corresponde a duas vezes o diâmetro do parafuso.

\section{4 - RESUMOS DOS RESULTADOS PRINCIPAIS E SECUNDÁRIOS}

As tabelas 5.17 a 5.22 apresentam os resultados com os valores médios da massa específica, do teor de umidade e da resistência, para as espécies estudadas.

Tabela 5.18 - Resistência para parafusos fixos paralelo às fibras - Pinus Taeda.

\begin{tabular}{|c|c|c|c|c|}
\hline $\begin{array}{c}\text { Número de } \\
\text { parafusos }\end{array}$ & Obs. & $\begin{array}{c}\text { Massa específica } \\
\left(\mathrm{g} / \mathrm{cm}^{3}\right)\end{array}$ & $\begin{array}{c}\text { Umidade } \\
(\%)\end{array}$ & $\begin{array}{c}\text { Resistência } \\
\text { média } \\
(\mathrm{N} / \mathrm{mm})\end{array}$ \\
\hline 4 & Ensaios principais & 0,46 & 10,1 & 165 \\
\hline 8 & Ensaios principais & 0,46 & 9,6 & 146 \\
\hline 16 & Ensaios principais & 0,45 & 8,9 & 127 \\
\hline 4 & $\begin{array}{c}\text { Massa específica - } \\
\text { Menor }\end{array}$ & 0,44 & 11,4 & 170 \\
\hline 4 & $\begin{array}{c}\text { Massa específica - } \\
\text { Maior }\end{array}$ & 0,51 & 10,6 & 169 \\
\hline 4 & Espaçamento $15 \mathrm{~mm}$ & 0,47 & 9,4 & 166 \\
\hline 4 & Espaçamento 30 mm & 0,46 & 9,2 & 151 \\
\hline 4 & Espaçamento 45 mm & 0,50 & 9,2 & 170 \\
\hline
\end{tabular}

Tabela 5.19 - Resistência para parafusos fixos perpendiculares às fibras - Pinus Taeda.

\begin{tabular}{|c|c|c|c|c|}
\hline $\begin{array}{c}\text { Número de } \\
\text { parafusos }\end{array}$ & Obs. & $\begin{array}{c}\text { Massa específica } \\
\left(\mathrm{g} / \mathrm{cm}^{3}\right)\end{array}$ & $\begin{array}{c}\text { Umidade } \\
(\%)\end{array}$ & $\begin{array}{c}\text { Resistência } \\
\text { média } \\
(\mathrm{N} / \mathrm{mm})\end{array}$ \\
\hline 4 & Ensaios principais & 0,47 & 13,1 & 174 \\
\hline 8 & Ensaios principais & 0,48 & 12,9 & 109 \\
\hline 4 & $\begin{array}{c}\text { Massa específica - } \\
\text { Menor }\end{array}$ & 0,41 & 12,4 & 139 \\
\hline 4 & $\begin{array}{c}\text { Massa específica - } \\
\text { Maior }\end{array}$ & 0,47 & 11,6 & 157 \\
\hline
\end{tabular}


Tabela 5.20 - Resistência para parafusos fixos paralelo às fibras - Eucalipto Grandis

\begin{tabular}{|c|c|c|c|c|}
\hline $\begin{array}{c}\text { Número de } \\
\text { parafusos }\end{array}$ & Obs. & $\begin{array}{c}\text { Massa específica } \\
\left(\mathrm{g} / \mathrm{cm}^{3}\right)\end{array}$ & $\begin{array}{c}\text { Umidade } \\
(\%)\end{array}$ & $\begin{array}{c}\text { Resistência média } \\
(\mathrm{N} / \mathrm{mm})\end{array}$ \\
\hline 4 & Ensaios principais & 0,69 & 12,5 & 196 \\
\hline 8 & Ensaios principais & 0,70 & 12,2 & 162 \\
\hline 16 & Ensaios principais & 0,73 & 12,7 & 166 \\
\hline 4 & $\begin{array}{c}\text { Massa específica - } \\
\text { Menor }\end{array}$ & 0,66 & 14,0 & 184 \\
\hline 4 & $\begin{array}{c}\text { Massa específica - } \\
\text { Maior }\end{array}$ & 0,74 & 12,8 & 194 \\
\hline 4 & Umidade 20\% & 0,68 & 22,1 & 145 \\
\hline 4 & Ponto de saturação & 0,71 & 27,1 & 137 \\
\hline
\end{tabular}

Tabela 5.21 - Resistência para parafusos fixos perpendiculares às fibras - Eucalipto Grandis

\begin{tabular}{|c|c|c|c|c|}
\hline $\begin{array}{c}\text { Número de } \\
\text { parafusos }\end{array}$ & Obs. & $\begin{array}{c}\text { Massa específica } \\
\left(\mathrm{g} / \mathrm{cm}^{3}\right)\end{array}$ & $\begin{array}{c}\text { Umidade } \\
(\%)\end{array}$ & $\begin{array}{c}\text { Resistência média } \\
(\mathrm{N} / \mathrm{mm})\end{array}$ \\
\hline 4 & Ensaios principais & 0,69 & 13,0 & 258 \\
\hline 8 & Ensaios principais & 0,74 & 12,9 & 133 \\
\hline 4 & $\begin{array}{c}\text { Massa específica - } \\
\text { Menor }\end{array}$ & 0,67 & 12,6 & 250 \\
\hline 4 & $\begin{array}{c}\text { Massa específica - } \\
\text { Maior }\end{array}$ & 0,72 & 12,6 & 262 \\
\hline 4 & Umidade 20\% & 0,68 & 21,9 & 236 \\
\hline 4 & Ponto de saturação & 0,69 & 24,6 & 238 \\
\hline
\end{tabular}

Tabela 5.22 - Resistência para parafusos fixos paralelo às fibras - Cupiúba

\begin{tabular}{|c|c|c|c|c|}
\hline $\begin{array}{c}\text { Número de } \\
\text { parafusos }\end{array}$ & Obs. & $\begin{array}{c}\text { Massa específica } \\
\left(\mathrm{g} / \mathrm{cm}^{3}\right)\end{array}$ & $\begin{array}{c}\text { Umidade } \\
(\%)\end{array}$ & $\begin{array}{c}\text { Resistência } \\
\text { média } \\
(\mathrm{N} / \mathrm{mm})\end{array}$ \\
\hline 4 & Ensaios principais & 0,77 & 11,7 & 206 \\
\hline 8 & Ensaios principais & 0,77 & 13,1 & 161 \\
\hline 16 & Ensaios principais & 0,77 & 11,1 & 158 \\
\hline
\end{tabular}

Tabela 5.23 - Resistência para parafusos fixos perpendiculares às fibras - Cupiúba

\begin{tabular}{|c|c|c|c|c|}
\hline $\begin{array}{c}\text { Número de } \\
\text { parafusos }\end{array}$ & Obs. & $\begin{array}{c}\text { Massa específica } \\
\left(\mathrm{g} / \mathrm{cm}^{3}\right)\end{array}$ & $\begin{array}{c}\text { Umidade } \\
(\%)\end{array}$ & $\begin{array}{c}\text { Resistência } \\
\text { média } \\
(\mathrm{N} / \mathrm{mm})\end{array}$ \\
\hline 4 & Ensaios principais & 0,84 & 14,0 & 242 \\
\hline 8 & Ensaios principais & 0,76 & 14,0 & 139 \\
\hline
\end{tabular}

\section{5 - SUGESTÃO PARA O CRITÉRIO DE DIMENSIONAMENTO}

É possível utilizar como referência de cálculo da resistência, em ligações que utilizem este tipo de parafuso submetido a esforços de tração, as recomendações enunciadas no item sobre condições de segurança da Norma "NBR 7190 - Projeto de Estruturas de Madeira”. 
Desta forma a segurança da estrutura com relação aos possíveis estados limites será garantida por:

$$
\mathrm{S}_{\mathrm{d}} \leq \mathrm{R}_{\mathrm{d}}
$$

onde:

$\mathrm{S}_{\mathrm{d}}$ - Solicitação de cálculo

$\mathrm{R}_{\mathrm{d}}$ - Resistência de cálculo

Considerando este caso especial ao utilizar parafusos torx auto-atarraxantes submetidos a esforços axiais de tração, é possível tomar a resistência de cálculo $R_{d}$ como fração da resistência característica $R_{k}$ estimada pela equação:

$$
\mathrm{R}_{\mathrm{d}}=\mathrm{K}_{\bmod } \frac{R_{k}}{\gamma_{w}}
$$

onde:

$\mathrm{R}_{\mathrm{d}}$ - Resistência de cálculo

$\mathrm{K}_{\text {mod }}$ - Coeficiente de modificação = módulo de 3 coeficientes de modificação

$\mathrm{R}_{\mathrm{k}}$ - Resistência característica

$\gamma_{\mathrm{w}}$ - Coeficiente de ponderação para os estados limites

Sugere-se utilizar, como referência inicial, os valores da resistência média igual a 165 N/mm para a espécie Pinus Taeda, 190 N/mm para o Eucalipto Grandis. Considerando o número reduzido de ensaios com 4 parafusos para a espécie Cupiúba, sugere-se para esta espécie o mesmo valor obtido para o Eucalipto Grandis. Estes valores de resistência são indicados ao utilizar os parafusos fixos paralelos às fibras.

Caso os parafusos estejam fixos perpendiculares às fibras, é possível utilizar os mesmos valores de resistência já citados, estando com certeza a favor da segurança. Além disto, de maneira geral, para o caso de treliças, a situação mais crítica será para a direção paralela às fibras, não ocorrendo a possibilidade de ruptura na peça na qual o parafuso está inserido na direção perpendicular às fibras.

Para ligações compostas por um número maior que 4 parafusos torx autoatarraxantes, sugere-se utilizar coeficiente de redução da resistência igual a 0,75.

Assim, sugere-se o critério de dimensionamento descrito a seguir, para o caso de parafusos dispostos paralelamente às fibras. 
A resistência de cálculo por unidade de comprimento de rosca é dada por:

$$
\mathrm{R}_{\mathrm{L}, \mathrm{d}}=\mathrm{R}_{\mathrm{L}, \mathrm{k}} \cdot \frac{k_{\mathrm{mod}}}{\gamma_{w}}
$$

onde:

$\mathrm{R}_{\mathrm{L}, \mathrm{d}}$ - Resistência de cálculo por unidade de comprimento de rosca

$\mathrm{R}_{\mathrm{L}, \mathrm{k}}$ - Valor característico da resistência

$\mathrm{K}_{\text {mod }}$ - Coeficiente de modificação

$\gamma_{w}$ - Coeficiente de ponderação para os estados limites

$\mathrm{O}$ valor da resistência de cálculo para a ligação $\left(\mathrm{R}_{\mathrm{d}}\right)$ é dado por:

$$
\mathrm{R}_{\mathrm{d}}=\mathrm{R}_{\mathrm{L}, \mathrm{d}} \cdot \mathrm{K}_{\text {grupo }} \cdot \mathrm{L}_{\mathrm{RE}} \cdot \mathrm{n}_{\mathrm{p}}
$$

onde:

$\mathrm{R}_{\mathrm{d}}$ - Resistência de cálculo

$\mathrm{R}_{\mathrm{L}, \mathrm{d}}$ - Resistência de cálculo por unidade de comprimento de rosca

$\mathrm{K}_{\text {grupo }}$ - Coeficiente de redução devido ao efeito de grupo

$\mathrm{L}_{\mathrm{RE}}$ - Comprimento de rosca efetivo na peça principal de madeira

$\mathrm{n}_{\mathrm{p}}$ - é o número de parafusos

De acordo com os resultados obtidos neste trabalho, pode-se sugerir os seguintes valores para os coeficientes:

$\mathrm{K}_{\text {mod.2 }}=1,0$ - para as classes de umidade (1) e (2)

$\mathrm{K}_{\text {mod.2 }}=0,7$ - para as classes de umidade (3) e (4)

$\mathrm{K}_{\text {grupo }}=1,0-$ para $\mathrm{n}_{\mathrm{p}} \leq 4$

$\mathrm{K}_{\text {grupo }}=0,75-$ para $\mathrm{n}_{\mathrm{p}} \geq 4$

Com relação aos espaçamentos mínimos é possível adotar para parafusos submetidos a esforços de tração o corresponde a duas vezes o diâmetro do parafuso. 


\section{6 - COMPARAÇÃO ENTRE OS CRITÉRIOS DE DIMENSIONAMENTO DAS NORMAS CONSULTADAS E O CRITÉRIO SUGERIDO}

Esta comparação será feita calculando o valor da resistência para um parafuso fixo paralelo às fibras, para o caso de massa específica igual a $500 \mathrm{~kg} / \mathrm{m}^{3}$, valor próximo ao obtido para o Pinus Taeda, será considerada madeira seca ao ar, diâmetro do parafuso igual a 7,5 $\mathrm{mm}$ e comprimento de rosca inserida igual a $80 \mathrm{~mm}$, sendo o comprimento de rosca efetivo igual a $72,5 \mathrm{~mm}$.

É importante salientar que esta comparação tem por objetivo apenas avaliar os procedimentos indicados no item anterior. Deve ser observado que os critérios das normas consultadas se aplicam para parafusos auto-atarraxantes de tipos diferentes do parafuso torx estudado neste trabalho.

\subsection{1 - Critérios Baseados no Método das Tensões Admissíveis}

- Para a norma alemã DIN 1052 - STRUCTURAL USE OF TIMBER do DEUSTCHES INSTITUT FÜR NURMING (1988) utilizando a equação 10 é obtido a seguinte resistência de tração por parafuso. A comparação será exemplificada adotando os seguintes dados:

- Diâmetro do parafuso: 7,5 mm,

- Comprimento de rosca inserido na madeira: $80 \mathrm{~mm}$.

$\mathrm{R}_{\mathrm{ad}, 0}=3 \cdot \mathrm{L}_{\mathrm{R}} \cdot \mathrm{d}=3 \cdot 80 \cdot 7,5=1800 \mathrm{~N}=1,80 \mathrm{kN}$

- Para a norma norte-americana NDS-91 - NATIONAL DESIGN SPECIFICATION FOR WOOD CONSTRUCTION do AMERICAN NATIONAL STANDARD (1991), o valor da resistência é apresentado em uma tabela em libras por polegada, utilizando como exemplo os seguintes dados:

- Diâmetro do parafuso: 7,5 mm ou 5/16",

- Massa específica da madeira: $0,50 \mathrm{~g} / \mathrm{cm}^{3}$,

- Comprimento de rosca efetivo, inserido na madeira: $72,5 \mathrm{~mm}$ ou 2,85 polegadas.

Para um parafuso fixo paralelo às fibras, a resistência obtida é: 
$\mathrm{R}_{\mathrm{ad}, 0}=(0,9 \cdot 0,8 \cdot 0,75) \cdot(2,85 \cdot 266)=1,86 \mathrm{kN}$

- No WOOD HANDBOOK do FOREST PRODUCTS LABORATORY (1999), para parafuso de fenda para madeira utiliza-se para o cálculo da resistência da ligação a equação 18. Os dados utilizados foram:

- Diâmetro do parafuso: 7,5 mm,

- Massa específica da madeira: $0,50 \mathrm{~g} / \mathrm{cm}^{3}$,

- Comprimento de rosca inserida na madeira: $80 \mathrm{~mm}$.

Portanto, o valor obtido da resistência, ao aplicar-se o coeficiente de segurança com valor igual a 6 , é:

$\mathrm{R}_{\mathrm{ad}, 0}=108,25 \cdot \rho^{2} \cdot \mathrm{d} \cdot \mathrm{L}_{\mathrm{R}}=\left(108,25 \cdot 0,5^{2} \cdot 7,5 \cdot 80 \cdot 0,75\right) \div 6=2029 \mathrm{~N}=2,03 \mathrm{kN}$

Para parafusos auto-atarraxantes, a resistência da ligação aplicando a equação 19 e utilizando os dados sugeridos anteriormente, com coeficiente de segurança de valor igual a 5, é:

$R_{\mathrm{ad}, 0}=125,4 \cdot \rho^{3 / 2} \cdot \mathrm{d}^{3 / 4} \cdot \mathrm{L}_{\mathrm{R}}=2411 \mathrm{~N}=2,41 \mathrm{kN}$

\subsection{2 - Critérios Baseados no Método dos Estados Limites}

- A norma da comunidade européia EUROCODE 5 - DESIGN OF TIMBER STRUCTURES do EUROPEAN PRESTANDARD (1993), utilizando-se as equações 11 e 12, a partir dos dados a seguir, é obtida a resistência:

- Diâmetro do parafuso: 7,5 mm,

- Comprimento de rosca inserida na madeira: $80 \mathrm{~mm}$,

- Massa específica: $500 \mathrm{~kg} / \mathrm{m}^{3}$.

$f_{3, d}=\frac{0,70}{1,30} \cdot\left[(1,5+0,6 d) \cdot \rho^{1 / 2}\right]=72,24 N / m m$

$\mathrm{R}_{\mathrm{d}, 0}=\mathrm{f}_{3, \mathrm{~d}} \cdot\left(\mathrm{L}_{\mathrm{R}}-\mathrm{d}\right)=5237 \mathrm{~N}=5,24 \mathrm{kN}$ 
- Por meio da norma canadense ENGINEERING DESIGN IN WOOD SUPPLEMENT $\mathrm{N}^{\mathrm{O}}$ 1-93, da CANADIAN STANDARS ASSOCIATION (1993) utilizando-se a equação 13, é obtida a seguinte resistência de tração, a partir dos dados abaixo:

- Diâmetro do parafuso: 7,5 mm,

- Comprimento de rosca inserida na madeira: $80 \mathrm{~mm}$,

- Massa específica da madeira: $0,50 \mathrm{~g} / \mathrm{cm}^{3}$.

$$
\mathrm{R}_{\mathrm{d}, 0}=\phi \cdot \mathrm{Y}_{\mathrm{w}} \cdot \mathrm{L}_{\mathrm{R}} \cdot \mathrm{n}_{\mathrm{p}}=(0,6 \cdot 42 \cdot 80) \cdot 0,75=1512 \mathrm{~N}=1,51 \mathrm{kN}
$$

- A Norma australiana TIMBER STRUCTURES - PART 1: DESIGN METHODS da STANDARDS ASSOCIATION OF AUSTRALIA (1994), por meio das equações 14,15 e 16, possibilita o cálculo da resistência da ligação. O valor f da equação é tabelado e depende do diâmetro do parafuso, sendo o valor mais próximo ao estipulado para a realização dos cálculos igual a $8 \mathrm{~mm}$ para o diâmetro do parafuso. O comprimento de rosca inserida é de $80 \mathrm{~mm}$ e o grupo de espécie é o JD4, para madeira seca ao ar.

$\mathrm{R}_{\mathrm{d}, 0}=\mathrm{k}_{13} \cdot \mathrm{f}=0,8 \cdot[0,6 \cdot(87 \cdot 72,5)]=3028 \mathrm{~N}$ ou $3,03 \mathrm{kN}$

- Por meio do critério de dimensionamento proposto neste trabalho e das informações da norma "NBR 7190/97 - Projeto de Estruturas de Madeira", pode-se avaliar a resistência, através das equações 20 e 21, a partir dos dados fornecidos.

O valor médio da resistência obtida para o Pinus Taeda é:

$\mathrm{R}_{\mathrm{L}, \mathrm{m}}=165 \mathrm{~N} / \mathrm{mm}$

Considerando o coeficiente de variação para a ligação como sendo igual a $18 \%$, mesmo valor estipulado para a maioria das resistências da madeira, o valor característico da resistência $\mathrm{R}_{\mathrm{L}, \mathrm{k}}$ pode ser estimado por:

$$
\mathrm{R}_{\mathrm{L}, \mathrm{k}}=165 \cdot 0,70=115,5 \mathrm{~N} / \mathrm{mm}
$$


Adotando-se os seguintes coeficientes de modificação $\left(K_{\text {mod }}\right)$ e de ponderação da resistência $\left(\gamma_{\mathrm{w}}\right)$ :

$\mathrm{K}_{\bmod 1}=0,70$ - corresponde à classe de carregamento de longa duração;

$\mathrm{K}_{\bmod 2}=1,00-$ para as classes de umidade (1) e (2)

$\mathrm{K}_{\text {mod } 3}=0,80$ - para madeira de $2^{\mathrm{a}}$ categoria.

$\gamma_{\mathrm{w}}=1,8$

O valor de cálculo da resistência por unidade de comprimento é:

$\mathrm{R}_{\mathrm{L}, \mathrm{d}}=\mathrm{R}_{\mathrm{L}, \mathrm{k}} \cdot \frac{k_{\mathrm{mod}}}{\gamma_{w}}=\frac{115,5 \cdot 0,7 \cdot 1,0 \cdot 0,8}{1,8}=36 \mathrm{~N} / \mathrm{mm}$

O valor da resistência de cálculo, considerando um parafuso, é:

$\mathrm{R}_{\mathrm{d}}=\mathrm{R}_{\mathrm{L}, \mathrm{d}} \cdot \mathrm{K}_{\text {grupo }} \cdot \mathrm{L}_{\mathrm{RE}} \cdot \mathrm{n}_{\mathrm{p}}=36 \cdot 1,0 \cdot 72,5 \cdot 1=2610 \mathrm{~N}=2,61 \mathrm{kN}$

Obviamente, cada norma adota métodos diferentes, bem como coeficientes de ponderação das ações e das resistências diferentes. A tabela 5.24 apresenta o resumo dos resultados desta comparação.

Tabela 5.24 - Resumo dos resultados - Comparação entre critérios de dimensionamentos

\begin{tabular}{|c|c|c|}
\hline Método das Tensões Admissíveis & \multicolumn{2}{|c|}{ Resultados Obtidos (kN) } \\
\hline DEUSTCHES INSTITUT FÜR NURMING (1988) & \multicolumn{2}{|c|}{$1,80(2,52)$} \\
\hline AMERICAN NATIONAL STANDARD (1991) & \multicolumn{2}{|c|}{$1,86(2,60)$} \\
\hline FOREST PRODUCTS LABORATORY (1999) & $2,03(2,84)$ & $2,41(3,37)$ \\
\hline Método dos Estados Limites & \multicolumn{2}{|c|}{ Resultados Obtidos (kN) } \\
\hline EUROPEAN PRESTANDARD (1993) & \multicolumn{2}{|c|}{5,24} \\
\hline CANADIAN STANDARS ASSOCIATION (1993) & \multicolumn{2}{|c|}{1,51} \\
\hline STANDARDS ASSOCIATION OF AUSTRALIA (1994) & \multicolumn{2}{|c|}{3,03} \\
\hline CRITÉRIO DE DIMENSIONAMENTO PROPOSTO & \multicolumn{2}{|c|}{2,61} \\
\hline
\end{tabular}


Para comparação adequada entre os valores obtidos pelo Método das Tensões Admissíveis e o Método dos Estados Limites, os valores obtidos pelo primeiro método foram multiplicados por 1,4, para considerar os coeficientes de ponderação das ações. O resultado desta multiplicação está apresentado entre parêntesis, na tabela 5.24

De maneira aproximada, pode-se concluir pela adequada concordância do resultado obtido pelo critério sugerido com os resultados obtidos pelos demais métodos, exceto o EUROCODE, que leva a resultado muito superior. 


\section{CONCLUSÕES}

Este trabalho teve como objetivo verificar a viabilidade de aplicação e avaliar a resistência de uma forma alternativa de ligação, na qual se utilizam parafusos torx autoatarraxantes solicitados por esforços de tração, diferente das ligações convencionalmente utilizadas, nas quais os parafusos atuam como pinos, estando solicitados por cisalhamento.

Este arranjo de ligação demonstrou ser exeqüível em estruturas de madeira, graças ao tipo de parafuso e à resistência obtida nas ligações. Assim, esta configuração de ligação futuramente poderá apresentar vantagem em relação a outros tipos de ligações atualmente empregados, em virtude da facilidade de sua execução, o que possibilita a industrialização das estruturas de madeira e, conseqüentemente, uma maior produtividade na execução de estruturas, reduzindo seu custo final.

No decorrer dos ensaios realizados, ficou evidenciado que a ferramenta ideal para fixar parafuso auto-atarraxantes é a parafusadeira com regulagem de torque, pois mantém em perfeitas condições os parafusos e as ferramentas, evitando quebras e aplicando o torque necessário para a fixação do parafuso.

Por meio da análise estatística realizada nos ensaios preliminares, foi possível constatar que as espécies de madeira e a pré-furação são fatores que causam variações importantes na resistência da ligação.

Com relação à pré-furação, esta deve ser feita de maneira a proporcionar maior resistência e também facilidade de execução das ligações. Para este caso específico, em que foi utilizado o parafuso torx auto-atarraxante, sugere-se utilizar como diâmetro da pré-furação os seguintes valores: 5,5 mm para a espécie Pinus Taeda, que equivalente a 0,73 do diâmetro do parafuso e 6,0 mm para as espécies Eucalipto Grandis e Cupiúba; esta pré-furação corresponde a 0,80 do diâmetro do parafuso. $\mathrm{O}$ valor sugerido para as duas últimas espécies é em função de se obter uma maior facilidade para a execução das ligações.

Os valores médios de resistência indicados como referência inicial ao utilizarem os parafusos torx fixos paralelos às fibras são: 165 N/mm para a espécie Pinus Taeda, 190 N/mm para o Eucalipto Grandis e Cupiúba. 
Uma característica importante observada é o fato da resistência unitária do parafuso ser maior em um grupo com menor quantidade de parafusos. Para ligações compostas por um número maior que 4 parafusos torx auto-atarraxantes, sugere-se utilizar um coeficiente de redução da resistência igual a 0,75 .

Como a resistência obtida em testes com um parafuso será superior, sugere-se que futuros ensaios sejam realizados com 4 parafusos. Acredita-se que este número de parafusos seja o mais freqüente em estruturas treliçadas para coberturas.

O teor de umidade tem grande importância pois é um fator que interfere de maneira significativa na resistência da ligação. Sugere-se utilizar um coeficiente de modificação igual a 0,70 quando for utilizar madeira para as classes de umidade 3 e 4 .

Para os espaçamentos entre parafusos, os resultados permitem concluir que não interferem na resistência da ligação, de maneira significativa. Sugere-se utilizar espaçamentos mínimos iguais a duas vezes o diâmetro dos parafusos.

Para finalizar, cabe uma observação importante, ao utilizar parafusos torx autoatarraxantes em projetos de estruturas de madeira submetidos aos esforços de tração, é necessário verificar a resistência do parafuso, quanto ao escoamento e/ou ruptura do aço. 


\section{REFERÊNCIAS BIBLIOGRÁFICAS}

AMERICAN NATIONAL STANDARD (1991). National Design Specification for wood Construction. Washington, U.S.A.

AMERICAN SOCIETY FOR TESTING AND MATERIALS - ASTM (1982). Part. 22 wood, adhesives. Annual Book of ASTM Standards. Philadelphia, PA. USA.

ASSOCIAÇÃO BRASILEIRA DE NORMAS TÉCNICAS (1997). NBR 7190 - Projeto de Estruturas de Madeira. Rio de Janeiro. ABNT.

BREYER, D. E. (1980). Design of wood structures. Cap. 12. ed. Mc Graw Hill Book Company.

CHIAVERINI, V. (1984). Aços e ferros fundidos - características gerais, tratamento térmico, principais tipos. Associação Brasileira de Metais. $5^{0}$ - edição. São Paulo.

COMITÉ EUROPÉEN DE NORMALISATION (1993). EUROCODE 5 - Design of timber structures. Brussels.

DEUSTCHES INSTITUT FÜR NURMING (1988). DIN 1052 - Structural use of timber Design and construction. Berlin.

ECKELMAN, C.A. (1975). Screwholding perfomance in hardwoods and particleboard. Revista: Forest Products Journal. Vol. 25. N . 6. p 30-35.

CANADIAN STANDARDS ASSOCIATION (1993). Engineering design in wood (Limit States Design) - supplement N ${ }^{0}$ 1-93 to CAN/CSA - 086.1 - M89. Canada.

FAHERTY, K. F. (1984). Structural wood research. American Society of Civil Engineers. New York. U.S.A.

FEIRER, J. L. (1963). Woodworking for industry. Unit 36. Michigan, U.S.A. ed. Bennett. 
FOREST PRODUCTS LABORATORY (1999). Wood handbook: Wood as an engineering material. Gen. Tech. Rep. FPL-GTR-113. Madison, WI: U.S. Department of Agriculture, Forest Products Laboratory. 463 p.

LISBOA, C. R. (1998). Ligações de peças estruturais de madeira. São Carlos. 503p. Tese (Doutorado) - Escola de Engenharia de São Carlos, Universidade de São Paulo.

MCLAIN, T. E. (1997) Design axial withdrawal strength from wood: I. Wood screws and lag screws. Revista: Forest Products Journal. Volume 47. Edição $N^{0}$. 5. May.

MISCHLER, A. (2000). Verbindungen und verstärkungen mit axial beanspruchten schrauben. Technick in holzbau. SAH - Schweizerische Arbeitsgemeinschaft für Holzforschung.

NEWLIN, J. A.; GAHAGAN, J. M. (1938). Lag-screw joints: their behavior and design. Technical Bulletin $\mathrm{N}^{\circ}$. 597. U.S. Department of Agriculture. 27p.

PASSOS, M. E. M.; CHAHUD, E. (1995). Comportamento do parafuso auto-atarraxante em ligações. In: $5^{\circ}$ ENCONTRO BRASILEIRO EM MADEIRAS E ESTRUTURAS DE MADEIRAS. Belo Horizonte, Brasil, 19-21 julho de 1995. Volume 2, Ligações, Páginas 357365.

SFS (2002) - Made by SFS, Fastening technology construction, for timber construction http://www.sfs.ch

STALNAKER, J. J.; HARRIS, E. C. (1989). Structural design in wood. University of Colorado at Denver. U.S.A. Van Norstrand Reinhold. p. 81-86.

STANDARDS ASSOCIATION OF AUSTRALIA (1994). Timber structures - part 1: Design methods - Australian Standard. Austrália.

VAZ, J. (1987). Silos verticais de madeira compensada. São Carlos. 346p. Dissertação (mestrado) - Escola de Engenharia de São Carlos, Universidade de São Paulo. 